Prepared in cooperation with the Albany Water, Gas, and Light Commission

\title{
Hydrologic Conditions, Groundwater Quality, and Analysis of Sinkhole Formation in the Albany Area of Dougherty County, Georgia, 2009
}

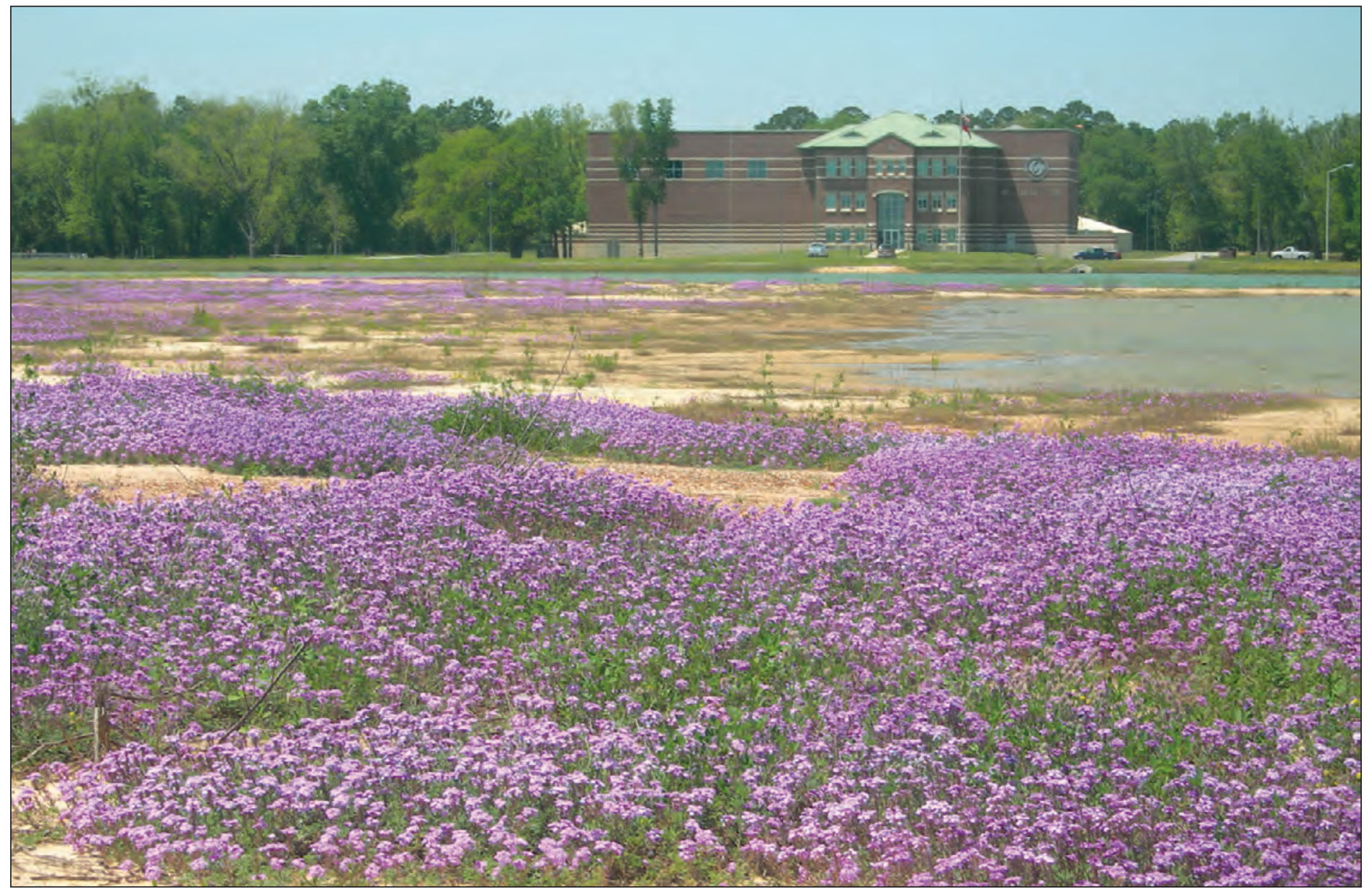

Scientific Investigations Report 2012-5018 
Cover. Water treatment facility at Albany Water, Gas, and Light Commission well field, April 2009, Albany, Georgia. Photo by Debbie Warner Gordon, U.S. Geological Survey. 


\section{Hydrologic Conditions, Groundwater Quality, and Analysis of Sinkhole Formation in the Albany Area of Dougherty County, Georgia, 2009}

By Debbie Warner Gordon, Jaime A. Painter, and John M. McCranie

Prepared in cooperation with the Albany Water, Gas, and Light Commission

Scientific Investigations Report 2012-5018 


\title{
U.S. Department of the Interior \\ KEN SALAZAR, Secretary \\ U.S. Geological Survey \\ Marcia K. McNutt, Director
}

\section{U.S. Geological Survey, Reston, Virginia: 2012}

\begin{abstract}
For more information on the USGS — the Federal source for science about the Earth, its natural and living resources, natural hazards, and the environment, visit http://Www.usgs.gov or call 1-888-ASK-USGS

For an overview of USGS information products, including maps, imagery, and publications, visit $h$ ttp://www.usgs.gov/pubprod

To order this and other USGS information products, visit http://store.usgs.gov
\end{abstract}

Any use of trade, product, or firm names is for descriptive purposes only and does not imply endorsement by the U.S. Government.

Although this report is in the public domain, permission must be secured from the individual copyright owners to reproduce any copyrighted materials contained within this report.

Suggested citation:

Gordon, D.W., Painter, J.A., and McCranie, J.M., 2012, Hydrologic conditions, groundwater quality, and analysis of sink hole formation in the Albany area of Dougherty County, Georgia, 2009: U.S. Geological Survey Scientific Investigations Report 2012-5018, 60 p.; available online at http://pubs.usgs.gov/sir/2012/5018/. 


\section{Contents}

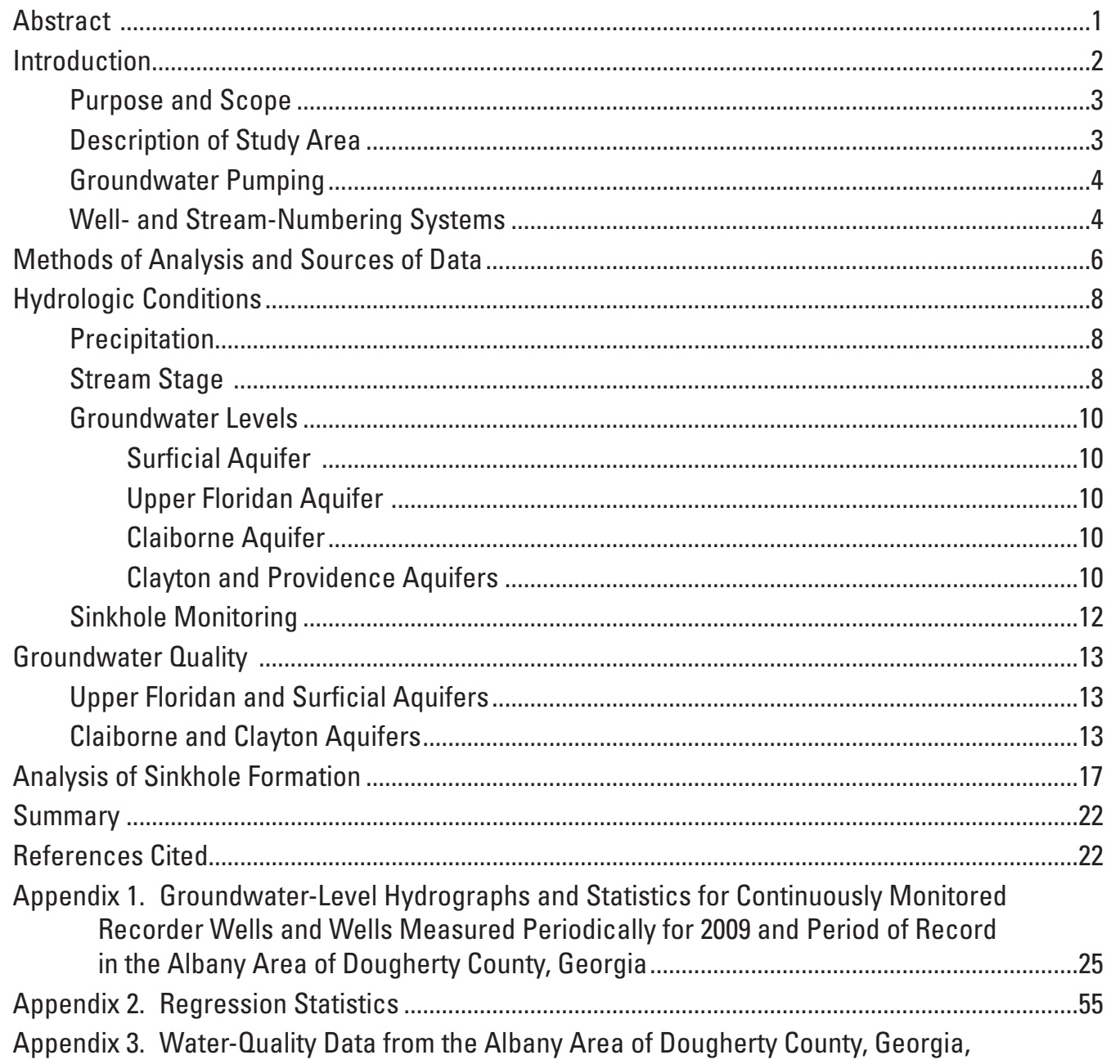

November 2009 


\section{Figures}

1. Map showing monitoring wells, streamgages, and the Albany Water, Gas, and Light Commission well field in the Albany area of Dougherty County, Georgia.

2. Correlation chart showing generalized stratigraphy and water-bearing units underlying Albany and surrounding areas, southwestern Georgia...

3-7. Graphs showing-

3. Water-use data for Dougherty County, Georgia, from 1980 through 2009: public supply and industrial water use and annualized daily average irrigation water use

4. Annual precipitation for the Albany area of Dougherty County, Georgia, 1957-2009

5. Precipitation data for Albany area, Georgia, January 1, 2005, through December 31, 2009: cumulative departure from normal precipitation for National Oceanographic and Atmospheric Administration Site, Albany 3 SE, and total daily precipitation for Georgia Automated Environmental Monitoring Network site, Albany State University

6. Daily mean gage height for the Flint River at Albany, Georgia (streamgage 02352500), 2009

7. Daily mean gage height for the Chickasawhatchee Creek gage near Leary, Georgia (streamgage 02354410), 2009.

8. Map showing potentiometric surface of the Upper Floridan aquifer in the Albany area of Dougherty County, Georgia, November 2-6, 2009.

9. Map showing location of sinkholes and production wells in the Albany well field, Dougherty County, Georgia

10. Graph showing the number of sinkholes that formed in the Albany well field, daily depth to water in well 12L382, and the depth to the top of the Upper Floridan aquifer at well 12L382, October 2003-December 2009

11. Map showing nitrate concentrations in the Upper Floridan aquifer and surficial aquifer, 2008 and 2009, and wells tested for pesticides during 2008 and 2009, Albany area, Georgia.

12. Graph showing nitrate concentrations in selected wells and the Flint River at Albany, Georgia, September 1998-November 2009.

13. Trilinear diagram showing water chemistry of the Upper Floridan aquifer and the Flint River at station 02352560 in the Albany area of Dougherty County, Georgia, November 2009

14. Three-dimensional geologic diagram of the well field in the Albany area of Dougherty County, Georgia

15. Map showing potentiometric surface of the Upper Floridan aquifer relative to the top of the Upper Floridan aquifer for selected periods at the Albany well field, February 5, 2007, through December 14, 2009 


\section{Appendix Figures}

1-1 to 1-2. Graphs showing periodic water levels in-

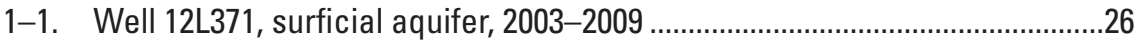

1-2. Well 12L376, surficial aquifer, 2002-2009 ………......................................27

$1-3$ to $1-10$. Graphs showing daily and monthly mean water levels in-

1-3. Well 11K003, Upper Floridan aquifer, 1979-2009........................................28

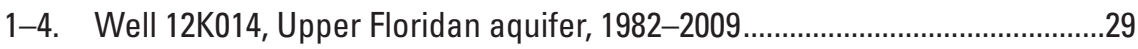

1-5. Well 12K141, Upper Floridan aquifer, 1996-2009..........................................30

1-6. Well 12K180, Upper Floridan aquifer, 2002-2009......................................31

1-7. Well 12L029, Upper Floridan aquifer, 1982-2009 ……....................................32

1-8. Well 12L030, Upper Floridan aquifer, 1985-2009 ………………...................33

1-9. Well 12L277, Upper Floridan aquifer, 1998-2009 .......................................34

1-10. Well 12L370, Upper Floridan aquifer, 2000-2009...........................................35

1-11. Graphs showing periodic water levels in well 12L372, Upper Floridan aquifer, 2000-2009.

1-12 to 1-20. Graphs showing daily and monthly mean water levels in-

1-12. Well 12L373, Upper Floridan aquifer, 2002-2009 ….....................................37

1-13. Well 12M017, Upper Floridan aquifer, 1982-2009........................................38

1-14. Well 13K014, Upper Floridan aquifer, 1982-2009.........................................39

1-15. Well 13L012, Upper Floridan aquifer, 1977-2009 .........................................40

1-16. Well 13L049, Upper Floridan aquifer, 1985-2009 .........................................41

1-17. Well 13L180, Upper Floridan aquifer, 1996-2009 …..................................42

1-18. Well 12L019, Claiborne aquifer, 1978-2009.................................................43

1-19. Well 13L011, Claiborne aquifer, 1977-2009...............................................44

1-20. Well 13L015, Claiborne aquifer, 1979-2009..............................................45

1-21 to 1-22. Graphs showing periodic water levels in-

1-21. Well 11K002, Claiborne aquifer, 1979-2009 ................................................

1-22. Well 11L001, Claiborne aquifer, 1979-2009...............................................47

1-23 to 1-29. Graphs showing daily and monthly mean water levels in-

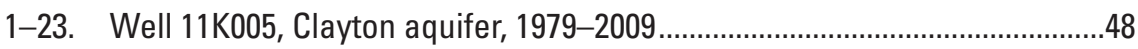

1-24. Well 11L002, Clayton aquifer, 1973-2009 …………...................................49

1-25. Well 12L020, Clayton aquifer, 1978-2009 ……………………...................50

1-26. Well 12M002, Clayton aquifer, 1978-2009...................................................

1-27. Well 13L002, Clayton aquifer, 1957-2009 ……........................................52

1-28. Well 13L013, Clayton aquifer, 1978-2009 ....................................................53

1-29. Well 12L021, Providence aquifer, 1978-2009 ..............................................54 


\section{Tables}

1. Continuous and periodic monitor wells and water-level trend for the period of record and from 2008 to 2009 for selected wells in Dougherty County, Georgia, and adjacent areas..

2. Nitrate data from selected wells and the Flint River in the Albany area of Dougherty County, Georgia, 1993 and 1998-2009.

\section{Appendix Tables}

2-1. Regression statistics used for estimating water-level trends in graphs in Appendix 1

3-1. Site information for water-quality data from the Albany area of

Dougherty County, Georgia, November 2009

3-2. Field parameters for water-quality samples from the Albany area of Dougherty County, Georgia, November 2009.

3-3. Major cations and anions from the Albany area of Dougherty County, Georgia, November 2009 .

3-4. Nutrients and biological data from the Albany area of Dougherty County, Georgia, November 2009 


\section{Conversion Factors and Datums}

\begin{tabular}{lcl}
\hline \multicolumn{1}{c}{ Multiply } & \multicolumn{1}{c}{ By } & \multicolumn{1}{c}{ To obtain } \\
\hline inch & Length & \\
foot (ft) & 2.54 & centimeter $(\mathrm{cm})$ \\
mile (mi) & 0.3048 & meter $(\mathrm{m})$ \\
\hline & 1.609 & kilometer $(\mathrm{km})$ \\
\hline foot per year (ft/yr) & Flow Rate & \\
million gallons per day (Mgal/d) & 0.3048 & meter per year $(\mathrm{m} / \mathrm{yr})$ \\
\hline
\end{tabular}

Temperature in degrees Celsius $\left({ }^{\circ} \mathrm{C}\right)$ may be converted to degrees Fahrenheit $\left({ }^{\circ} \mathrm{F}\right)$ as follows:

$$
{ }^{\circ} \mathrm{F}=\left(1.8 \times{ }^{\circ} \mathrm{C}\right)+32
$$

Vertical coordinate information is referenced to the National Geodetic Vertical Datum of 1929 (NGVD 29).

Horizontal coordinate information is referenced to the North American Datum of 1983 (NAD 83).

Altitude, as used in this report, refers to distance above the vertical datum.

Specific conductance is given in microsiemens per centimeter at 25 degrees Celsius $(\mu \mathrm{S} / \mathrm{cm}$ at $\left.25^{\circ} \mathrm{C}\right)$.

Concentrations of chemical constituents in water are given in milligrams per liter $(\mathrm{mg} / \mathrm{L})$ and in micrograms per liter $(\mu \mathrm{g} / \mathrm{L})$.

\section{Acronyms Used in this Report}

$\begin{array}{ll}\text { BHC } & \text { benzene hexachloride } \\ \text { DDT } & \text { dichlorodiphenyltrichloroethane } \\ \text { GaEPD } & \text { Georgia Environmental Protection Division } \\ \text { LMA } & \text { Levenberg-Marquardt } \\ \text { MCL } & \text { maximum contaminant level } \\ \text { NOAA } & \text { National Oceanic and Atmospheric Administration } \\ \text { NWIS } & \text { National Water Information System } \\ \text { USEPA } & \text { U.S. Environmental Protection Agency } \\ \text { USGS } & \text { U.S. Geological Survey } \\ \text { WGL } & \text { Albany Water, Gas, and Light Commission }\end{array}$

\section{Acknowledgments}

The authors appreciate the technical feedback, guidance, and data provided by staff of the Albany Water, Gas, and Light Commission, including Keith Goodin, Lee Daniel, Gary Morefield, and Jim Stolze. 



\title{
Hydrologic Conditions, Groundwater Quality, and Analysis of Sinkhole Formation in the Albany Area of Dougherty County, Georgia, 2009
}

\author{
By Debbie Warner Gordon, Jaime A. Painter, and John M. McCranie
}

\section{Abstract}

The U.S. Geological Survey, in cooperation with the Albany Water, Gas, and Light Commission has conducted water resources investigations and monitored groundwater conditions and availability in the Albany, Georgia, area since 1977. This report presents an overview of hydrologic conditions, water quality, and groundwater studies in the Albany area of Dougherty County, Georgia, during 2009. Historical data also are presented for comparison with 2009 data.

During 2009, groundwater-level data were collected in 29 wells in the Albany area to monitor water-level trends in the surficial, Upper Floridan, Claiborne, Clayton, and Providence aquifers. Groundwater-level data from 21 of the 29 wells indicated an increasing trend during 2008-09. Five wells show no trend due to lack of data and three wells have decreasing trends. Period-of-record water levels (period of record ranged between 1957-2009 and 2003-2009) declined slightly in 10 wells and increased slightly in 4 wells tapping the Upper Floridan aquifer; declined in 1 well and increased in 2 wells tapping the Claiborne aquifer; declined in 4 wells and increased in 2 wells tapping the Clayton aquifer; and increased in 1 well tapping the Providence aquifer.

Analyses of groundwater samples collected during 2009 from 12 wells in the Upper Floridan aquifer in the vicinity of a well field located southwest of Albany indicate that overall concentrations of nitrate plus nitrite as nitrogen increased slightly from 2008 in 8 wells. A maximum concentration of
12.9 milligrams per liter was found in a groundwater sample from a well located upgradient from the well field. The distinct difference in chemical constituents of water samples collected from the Flint River and samples collected from wells located in the well-field area southwest of Albany indicates that little water exchange occurs between the Upper Floridan aquifer and Flint River where the river flows adjacent to, but downgradient of, the well field. Water-quality data collected during 2008 from two municipal wells located in northern Albany and downgradient from a hazardous waste site indicate low-level concentrations of pesticides in one of the wells; however, no pesticides were detected in samples collected during 2009.

Detailed geologic cross sections were used to create a three-dimensional, hydrogeologic diagram of the well field southwest of Albany in order to examine the occurrence of subsurface features conducive to sinkhole formation. Monitored groundwater-level data were used to assess the possible relations between sinkhole formation, precipitation, and water levels in the Upper Floridan aquifer. Although the water levels in well 12L382 oscillated above and below the top of the aquifer on a regular basis between 2007 and 2009, sinkhole development did not appear to correlate directly with either well-field pumping or water levels in the Upper Floridan aquifer. Specifically, two sinkholes formed in each of the years 2003 and 2005 when water levels were almost 20 feet above the top of the aquifer during most of the year. Water-level and sinkhole-formation data continue to be collected to allow further study and analysis. 


\section{Introduction}

Long-term heavy pumping from the Claiborne, Clayton, and Providence aquifers has resulted in substantial water-level declines in the Albany, Georgia (Ga.), area (Hicks and others, 1981). For example, groundwater levels have declined more than 140 feet (ft) in the Clayton aquifer since 1940 (Hicks and others, 1987). To provide additional water supply and reduce the demand on these aquifers, in 2003 the Albany Water, Gas, and Light Commission (WGL) developed the WGL well field (fig. 1), which utilizes the Upper Floridan aquifer, a karstic unit that overlies the deeper Claiborne, Clayton, and Providence aquifers (fig. 2). The Upper Floridan aquifer is the uppermost reliable source of groundwater in the area; however, local recharge and unfavorable land-use practices threaten to degrade water quality in the aquifer. Concentrations of nitrate as nitrogen exceeding the 10-milligramsper-liter (mg/L) maximum contaminant level (MCL)
(U.S. Environmental Protection Agency, 2000) have been detected in some wells upgradient from the WGL well field.

Hydrologic, geologic, and water-quality data are needed to manage water resources effectively in the city of Albany and the Dougherty County area. Originally initiated in 1977, hydrologic investigations performed under a cooperative water program between the U.S. Geological Survey (USGS) and the WGL continue in an effort to address on-going concerns about the availability and quality of groundwater in the Albany area. The objectives of these long-term investigations are to (1) augment the current level of understanding of the hydrogeologic framework of the Upper Floridan aquifer near the WGL well field, (2) monitor water-level fluctuations in the four aquifers used in the area as well as evaluate waterlevel trends with respect to changes in climatic conditions and pumping patterns, and (3) evaluate and monitor water quality in the Upper Floridan aquifer as pumping patterns and land-use activities change.

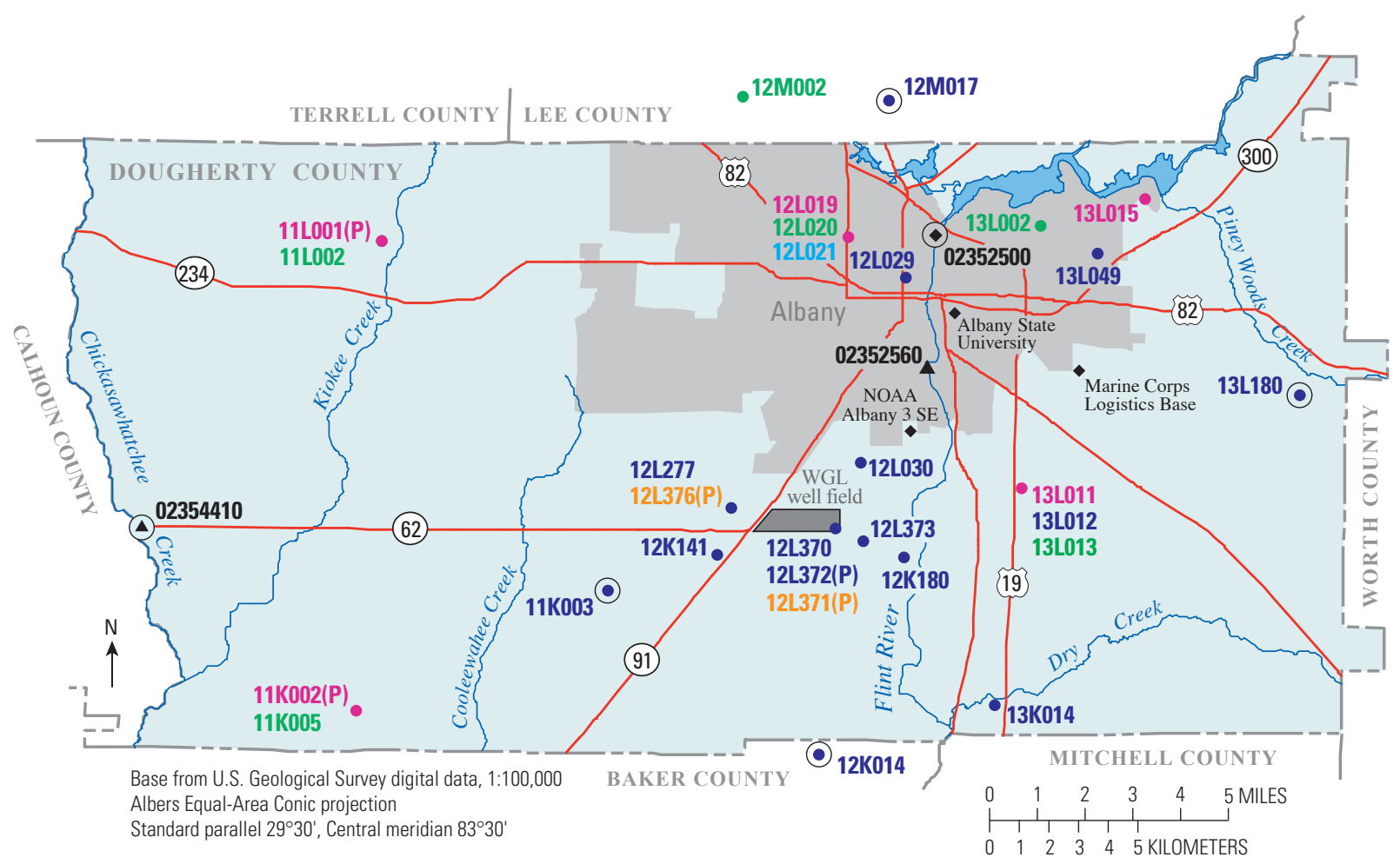

EXPLANATION

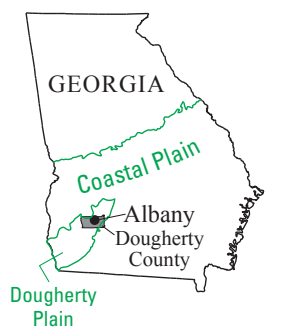

Monitoring well, identification, and aquifer- $(\mathrm{P})$ measured periodically

12L371(P) • Surficial aquifer

12L019(P) • Claiborne aquifer

12L372(P) • Upper Floridan

13L013 Clayton aquifer

12L021 Cretaceous aquifer system-

11K003 Real time

Providence aquifer

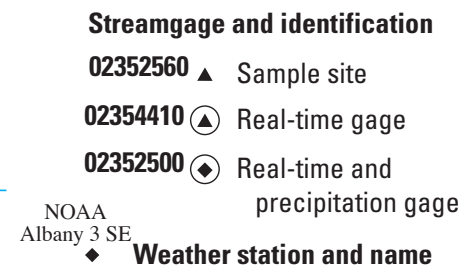

Figure 1. Monitoring wells, streamgages, and the Albany Water, Gas, and Light Commission (WGL) well field in the Albany area of Dougherty County, Georgia. [NOAA, National Oceanic and Atmospheric Administration] 


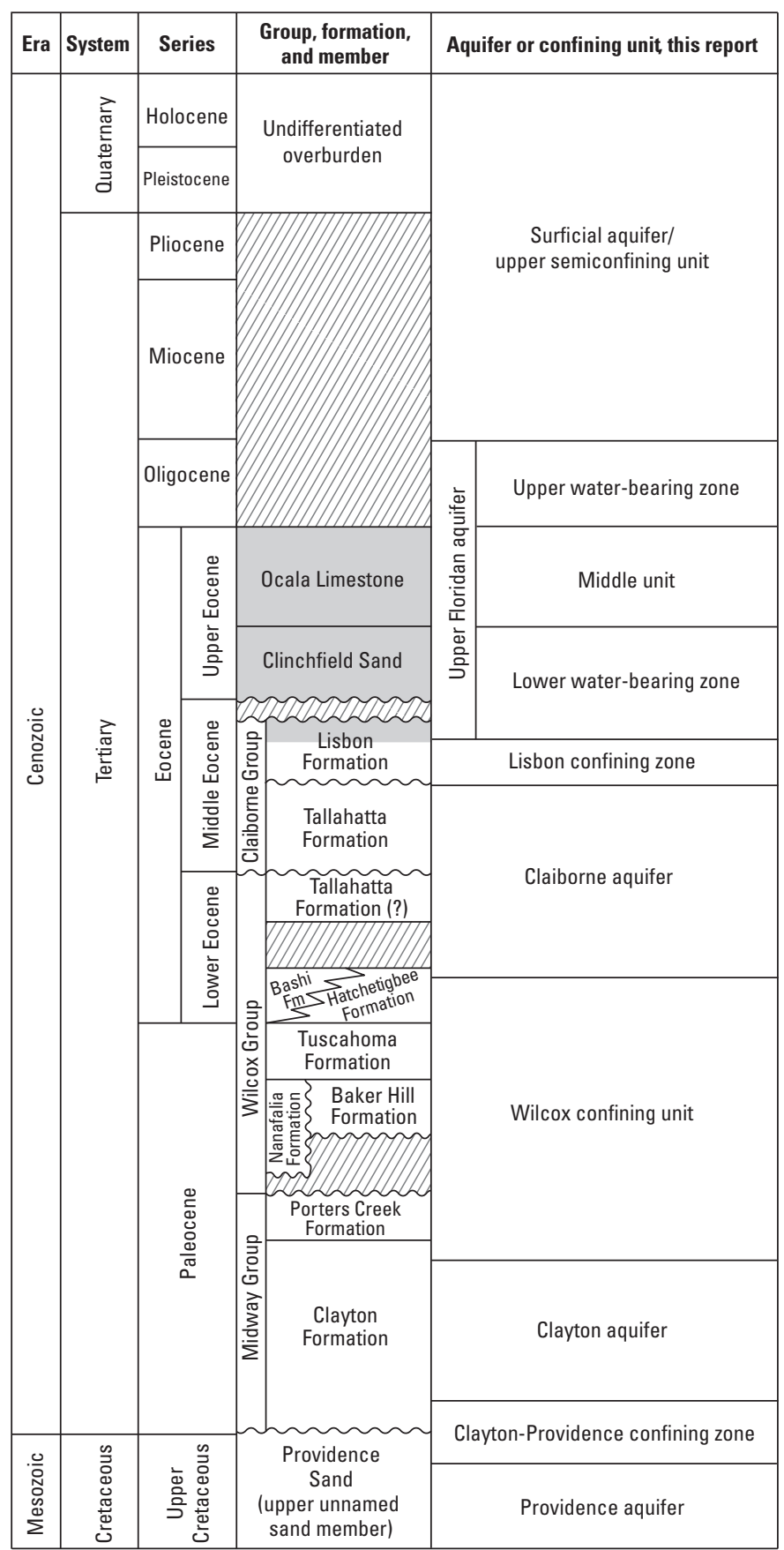

\section{EXPLANATION}

Sediments composing Upper Floridan aquifer

WIIJ Missing rocks

Figure 2. Generalized stratigraphy and water-bearing units underlying Albany and surrounding areas, southwestern Georgia (lower Eocene and older modified fom Clarke and others, 1984; middle Eocene and younger modified from Hicks and others, 1987). [Fm, formation]

\section{Purpose and Scope}

The purpose of this report, which is the fourth in a series begun in 2006, is to provide an overview of groundwater conditions and studies conducted in the Albany well-field area during 2009. This overview includes a summary of hydrologic conditions based on:

- Continuous water-level monitoring in a 24-well network (fig. 1);

- Construction of a potentiometric-surface map for the Upper Floridan aquifer based on 63 water-level measurements collected during November 2-6, 2009;

- Continuous monitoring of streamflow and precipitation at a streamgage on the Flint River (station 02352500), streamflow in Chickasawhatchee Creek (station 02354410), and precipitation at Albany State University;

- Collection of water-quality samples from 13 wells and one Flint River site near the WGL well field during November 3-6, 2009, for analysis of selected nutrients including dissolved nitrate plus nitrite as nitrogen (nitrate) and major cations and anions; and

- Collection of water samples and analysis for pesticides at one well downgradient from a hazardous waste site located north of Albany.

Water-level data for each continuously monitored well, nitrate concentrations from 1998 to 2009, precipitation data from 2005 to 2009, water-use data every 5 years from 1980 to 2005 , and water-use data (excluding irrigation water use) for 2007, 2008, and 2009 are presented. Detailed maps and geologic cross sections of the Albany well-field area were prepared to assess sinkhole development at the WGL well field.

\section{Description of Study Area}

The study area, Dougherty County, Ga., is in the Dougherty Plain district of the Coastal Plain Physiographic Province (Clark and Zisa, 1976) (fig. 1). Topography is karstic and relatively flat; land-surface altitudes range from about 160 to $200 \mathrm{ft}$ above NGVD 29. Numerous sinkholes are identified as depressions on topographic maps, and several of these contain water on a seasonal basis. Surface runoff is minimal because most of the drainage is internal due to the karst setting. The two major streams are the Flint River, and in the western part of the county, Cooleewahee Creek-a tributary to the Flint River. 
The primary land use in the study area is agricultural and includes cropland, pastures, orchards, and nurseries. The croplands consist mostly of row crops, pastures, and pecan orchards. Residential areas are located primarily within the city limits of Albany. Municipal sewer systems do not extend beyond the Albany city limits; therefore, residences outside of the city limits typically have individual septic systems. A regional airport, a few light industries, and commercial areas also are present.

Dougherty County is underlain by Coastal Plain sediments that gently dip and thicken to the southeast (Hicks and others, 1987). The geologic units relevant to this study are, in ascending order, Providence Sand, Clayton Formation, Porters Creek Formation, Nanafalia Formation, Baker Hill Formation, Tuscahoma Formation, Bashi Formation/Hatchetigbee Formation, Tallahatta Formation, Lisbon Formation, Clinchfield Sand, Ocala Limestone, and undifferentiated overburden (fig. 2; Clarke and others, 1984; Hicks and others, 1987). The hydrologic units relevant to this study, in descending order, are the surficial aquifer/upper semiconfining unit, Upper Floridan aquifer, Lisbon confining zone, Claiborne aquifer, Wilcox confining unit, Clayton aquifer, Clayton-Providence confining zone, and Providence aquifer (fig. 2; Clarke and others 1984; Hicks and others, 1987). Two zones of high permeability were identified within the Upper Floridan aquifer at the WGL well field using borehole geophysical and geologic logs. These zones contain more solution features than the overlying and underlying limestone.

\section{Groundwater Pumping}

The locations of groundwater pumping centers and amount of water withdrawn at these centers may affect groundwater levels in the Albany area of Dougherty County. Changes in pumping rates and the addition of new pumping centers may alter the configuration of potentiometric surfaces, reverse groundwater flow directions, and increase seasonal and long-term fluctuations in the aquifers.

The WGL provides water to its customers from several wells completed in the Claiborne and Clayton aquifers through a distribution system that extends throughout most of the city of Albany. In 2003, WGL began operating a well field located southwest of the city that pumps water from the Upper Floridan aquifer (fig. 1).
During 2009, groundwater withdrawals in Dougherty County (excluding irrigation pumping), totaled about 23.4 million gallons per day (Mgal/d) (fig. $3 A$ ). About 63 percent $(14.7 \mathrm{Mgal} / \mathrm{d})$ of the withdrawal was for public supply, and about 37 percent ( $8.7 \mathrm{Mgal} / \mathrm{d})$ was for industry (J.L. Fanning, U.S. Geological Survey, written commun., April 20, 2010). From 2008 to 2009, total withdrawal (excluding irrigation) decreased by $3.3 \mathrm{Mgal} / \mathrm{d}$. Although irrigation data are not currently available for 2009 , data collected at 5-year intervals are available for the period from 1980 to 2005. Irrigation pumping in Dougherty County increased from about $10.9 \mathrm{Mgal} / \mathrm{d}$ in 1995 to $20.3 \mathrm{Mgal} / \mathrm{d}$ in 2000 , and then decreased to about $10 \mathrm{Mgal} / \mathrm{d}$ in 2005 (fig. 3B). The increase in irrigation pumping from 1995 to 2000 reflects the drought that occurred from 1998 until late 2002 (J.L. Fanning, U.S. Geological Survey, written commun., May 27, 2009). The decrease from 2000 to 2005 corresponds to normal rainfall patterns that returned following the drought, which ended in late 2002.

\section{Well- and Stream-Numbering Systems}

In this report, wells are identified using a numbering system based on USGS topographic maps. In Georgia, each 7-1/2-minute topographic quadrangle map has been given a number and letter designation beginning at the southwestern corner of the State. Numbers increase eastward through 39, and letters increase alphabetically northward through " $Z$ " and then become double-letter designations "AA" through "PP." The letters "I," "O," "II," and "OO" are not used. Wells inventoried in each quadrangle are numbered sequentially beginning with "1." Thus, the 29th well inventoried in the Albany West quadrangle (map 12L) is designated 12L029. Springs are considered groundwater sites and are identified in the same manner as wells. Surface-water stations are identified by a numbering system used in all USGS reports and publications since October 1, 1950. The order of listing stations is in a downstream direction along the main channel. All stations along a tributary entering upstream from each main stem are listed prior to that station. Each surface-water station is assigned a unique 8- to 14-digit number. Each station number, such as 02352500 , begins with the 2-digit identifier " 02 ," which designates it as being a surface-water station, followed by the downstream-order number, "352500," which can range from 6 to 12 digits. 


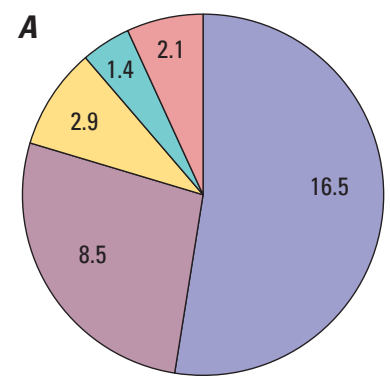

1980

$31.4 \mathrm{Mgal} / \mathrm{d}$

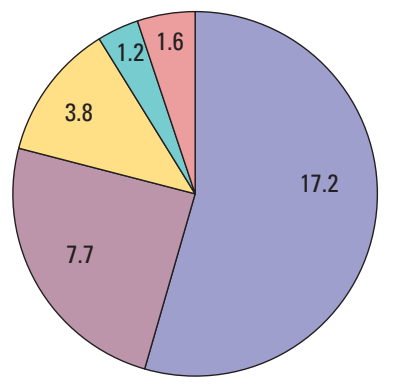

1985

$31.5 \mathrm{Mgal} / \mathrm{d}$

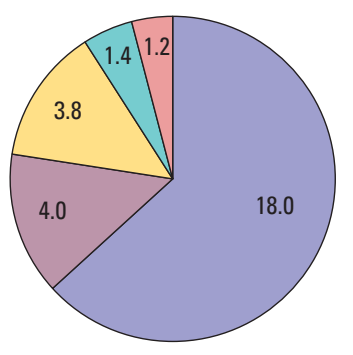

1990

28.4 Mgal/d
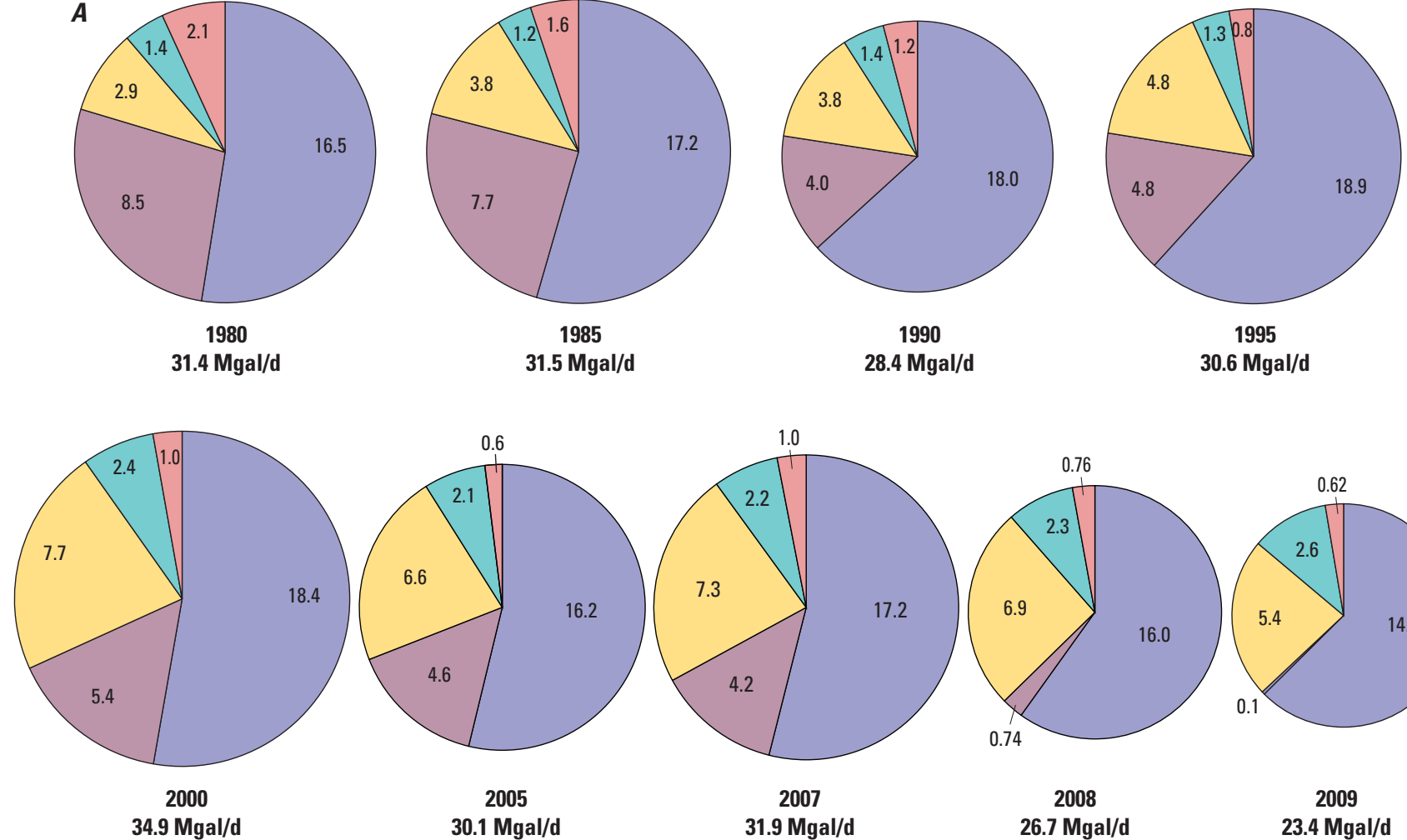

$30.1 \mathrm{Mgal} / \mathrm{d}$

2007

$31.9 \mathrm{Mgal} / \mathrm{d}$

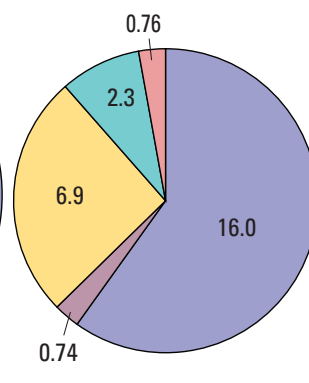

2008 26.7 Mgal/d

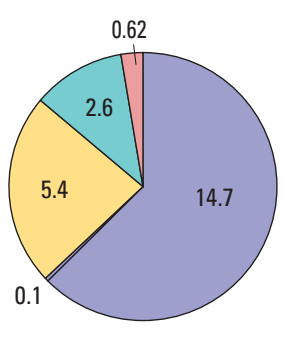

2009 23.4 Mgal/d
EXPLANATION

GROUNDWATER USE, IN MILLION GALLONS PER DAY (Mgal/d)

\section{Public supply}

City of Albany Water, Gas, and Light Commission

Industrial

Pharmaceutical

Paper and products

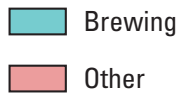

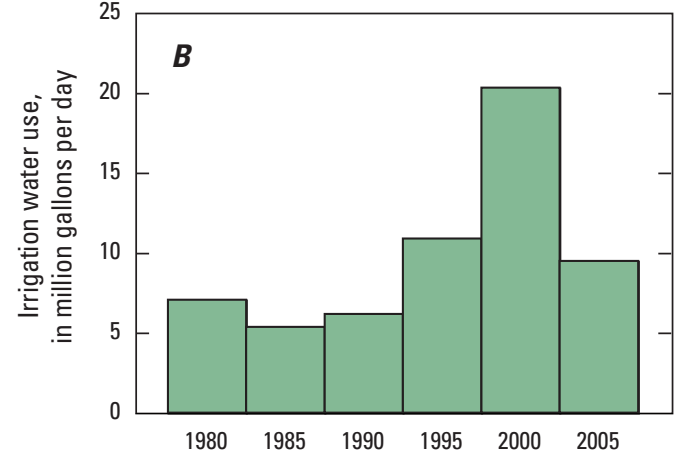

Figure 3. Water-use data for Dougherty County, Georgia, from 1980 through 2009. A. Public supply and industrial water use. $B$. Annualized daily average irrigation water use; irrigation data for 2009 are not yet available. 


\section{Methods of Analysis and Sources of Data}

To monitor precipitation in the Albany area, a real-time weather station at Albany State University is operated by the College of Agriculture and Environmental Sciences of The University of Georgia, and a real-time streamgage and precipitation site at the Flint River at Albany is operated by the USGS (station 02352500, fig. 1). Real-time data are those data collected continuously and transmitted by way of satellite every 15 minutes or hourly. Data for the Albany State University site are available at $h t t p: / / w w w . g e o r g i a w e a t h e r . n e t ;$ the data are now stored as historical data for Marine Corps Logistics Base, Albany, Ga. (Mathew Evans, written commun., August 10, 2011); and data for USGS site 02352500 are available at http://waterdata.usgs.gov/ga/nwis/ $u v / ?$ site_no $=02352500 \&$ PARAmeter_cd $=00045$ (accessed May 28, 2010). Air temperature and precipitation data, including daily and monthly normals for 1971-2000, are available from the National Oceanic and Atmospheric Administration (NOAA) climatological station Albany $3 \mathrm{SE}$ (fig. 1; http://cdo.ncdc.noaa.gov/climatenormals/clim84/GA/ GA090140.txt, accessed May 3, 2011).

Streamflow is monitored at the Flint River at Albany streamgage (station 02352500) and the Chickasawhatchee Creek near Leary, Ga., streamgage (station 02354410). The data are transmitted with real-time satellite telemetry, and water levels are recorded every 1 to 4 hours (based on equipment settings) for display on the USGS Georgia Water Science Center Web site at http://waterdata.usgs.gov/ga/ nwis/current/?type $=$ flow\&group_key=basin_cd (accessed September 28, 2010; Peck and others, 2009). The Flint River at Albany streamgage has operated since 1901, and the streamgage on Chickasawhatchee Creek has operated since
May 2001; however, the stage of Chickasawhatchee Creek has been measured periodically since 1954. Streamflow data for each site are available at http://waterdata.usgs.gov/ga/nwis/rt (accessed June 7, 2010).

Groundwater levels in the Albany area have been monitored for several decades. Water levels are continuously monitored in 24 wells and periodically monitored in 5 wells in the Albany area. Of the continuously monitored wells, 21 are in Dougherty County, 2 are in Lee County, and 1 is in Baker County (fig. 1). All five periodically measured wells are located in Dougherty County. The continuously monitored wells include 14 completed in the Upper Floridan aquifer, 3 completed in the Claiborne aquifer, 6 completed in the Clayton aquifer, and 1 completed in the Providence aquifer (fig. 1, table 1). All groundwater monitoring data are available at $h t t p: / /$ waterdata.usgs.gov/ga/nwis/dv? referred_module $=g w$ (accessed June 3, 2010). Appendix 1 contains hydrographs showing 2009 water levels, median daily water levels (based on 5 -year minimum period of record), and period-of-record water levels for 24 continuously monitored wells. Water-level hydrographs for the five periodically measured wells also are shown.

To illustrate long-term (period of record) and more recent (2008-2009) water-level changes, the Levenberg-Marquardt (LMA) method for minimization of a weighted least-squares merit function (Janert, 2010) was used to determine a straightline fit to both recent and period-of-record monthly mean groundwater levels (table 1, appendix 1; Peck and others, 2011). Estimated water levels from these straight-line fits were used to compute an annual rate of change (yearly slope) for the period of record and for 2008-2009. A more thorough discussion of the LMA method and associated summary statistics for the straight-line fits for each well are presented in appendix 2. Additional well information can be obtained from the USGS National Water Information System (NWIS) at http://waterdata.usgs.gov/ga/nwis/inventory/. 


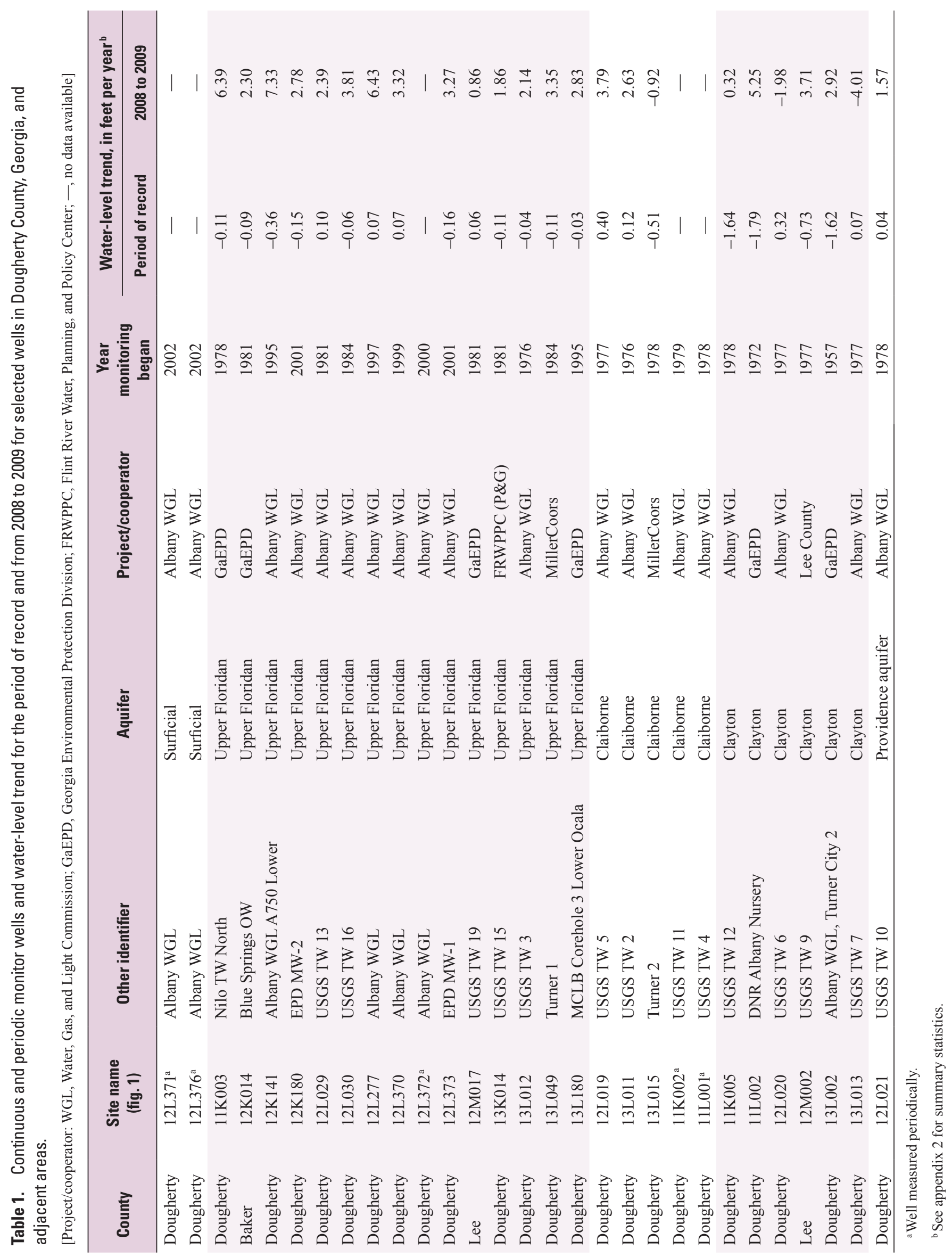




\section{Hydrologic Conditions}

Precipitation, streamflow, and groundwater levels were measured in the Albany area during 2009 to assess hydrologic conditions in the study area. Data collected to define the hydrologic conditions can be used by resource managers to help guide water-management decisions.

\section{Precipitation}

Precipitation in the Albany area influences groundwater levels in the shallow surficial aquifer, where present, and in the underlying Upper Floridan aquifer. The amount of precipitation also affects the quantities of groundwater withdrawn from deeper aquifers and, thus, has an indirect effect on groundwater levels in the Claiborne, Clayton, and Providence aquifers. A graph of annual precipitation data from 1957 through 2009 shows wet and dry periods for NOAA site Albany 3 SE (fig. 4). Major droughts occurred during 1980-82, 1985-89, 1998-2002 (Barber and Stamey, 2000), and 2006-2007. These droughts affected streamflow, pumping, and period-of-record water-level trends for each of the wells monitored in the study area. Most streams throughout Georgia recorded minimum flows during 1999, with recurrence intervals ranging from 20 to 50 years, and record minimum daily flows were established that year at three streamgaging stations along the Flint River (Barber and Stamey, 2000). The duration and severity of the 1998-2002 drought also had a major effect on groundwater levels, as indicated by period-of-record hydrographs (appendix 1, figs. 1-3,1-9). Water levels in the aquifers declined as pumping increased to offset the effects of diminished precipitation resulting from the prolonged drought.

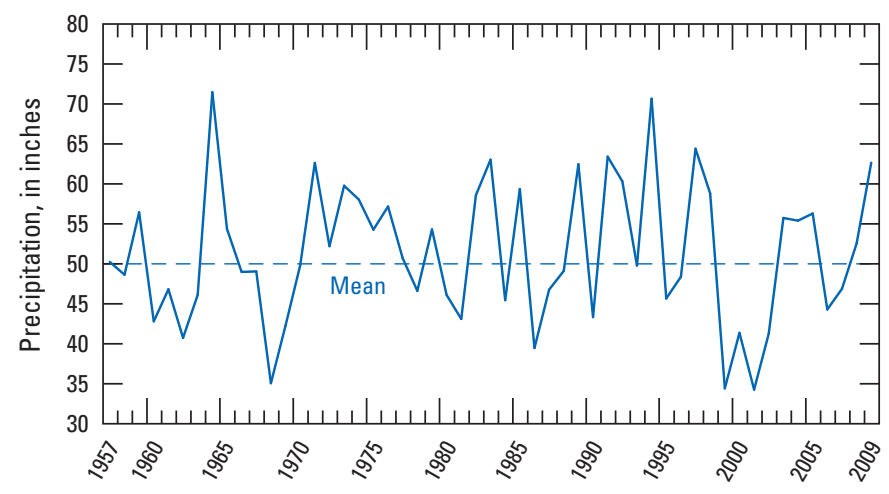

Figure 4. Annual precipitation for the Albany area of Dougherty County, Georgia, 1957-2009. Data for 1957-2007 is from National Oceanic and Atmospheric Administration site Albany 3 SE and for 2008-2009 is from Georgia Automated Environmental Monitoring network site, Albany State University.
The cumulative departure from normal precipitation can be used to evaluate trends in precipitation that typically relate to groundwater recharge. Cumulative departures from normal precipitation describe the surplus or deficit of precipitation during a designated period, and are derived by adding successive daily values of departures from normal precipitation. In this report, daily precipitation, in inches, from January 1, 2005, through December 31, 2009, for the Albany State University site, and 30-year (dynamic) normals for 1971-2000 from the NOAA site Albany 3 SE were used to calculate the cumulative departure from normal (data obtained from http://cdo.ncdc.noaa.gov/climatenormals/clim84/GA/ GA090140.txt, accessed May 29, 2009). Total daily precipitation data and the cumulative departure from normal for the period from January 1, 2005, through December 31, 2009, are shown in figure 5. A negative slope on the cumulative departure graph indicates below-normal precipitation and a positive slope indicates above-normal precipitation.

Following a precipitation deficit lasting from early 2006 through the first half of 2008, the cumulative departure data indicate normal to above-normal precipitation during 2009 (fig. 5A). A major precipitation event occurred from March 27 to April 4, 2009 (fig. 5B), when more than 11 inches of precipitation was recorded at the Flint River at Albany streamgage (station 02352500) (fig. 1).

\section{Stream Stage}

In 2009, the daily mean gage height of the Flint River at Albany station was below the long-term median daily value from January through March, was above the flood stage for the first part of April, was close to the median from late April through mid-October 2009, and was above the median daily value for the remainder of the year (fig. 6). In 2009, the daily mean gage height for the Chickasawhatchee Creek near Leary station was substantially higher than the long-term median value in April, May, June, August, September, and December 2009, and dropped below the median from late June through the end of July (fig. 7).

The gage-height data in figures 6 and 7 reflect the flooding that occurred in southwest Georgia during April 2-9, 2009, in response to more than 11 inches of precipitation that fell from March 27 to April 3, 2009, and were recorded at the Flint River at the Albany streamgage. The Flint River remained above the 20-ft flood stage for 8 days, and peaked at more than $11 \mathrm{ft}$ above flood stage on April 4, 2009 (http://waterwatch.usgs.gov/? $m=w w d p 2 \& r=g a$ $\& w=$ flood\%2Cmap, accessed July 12, 2010). A second period of flooding was recorded on the Flint River during December 16-21, 2009, in response to 7 inches of rain in Albany during December 12-18 (fig. 5). The Flint River peaked at $26.07 \mathrm{ft}$ on December 17, 2009. 

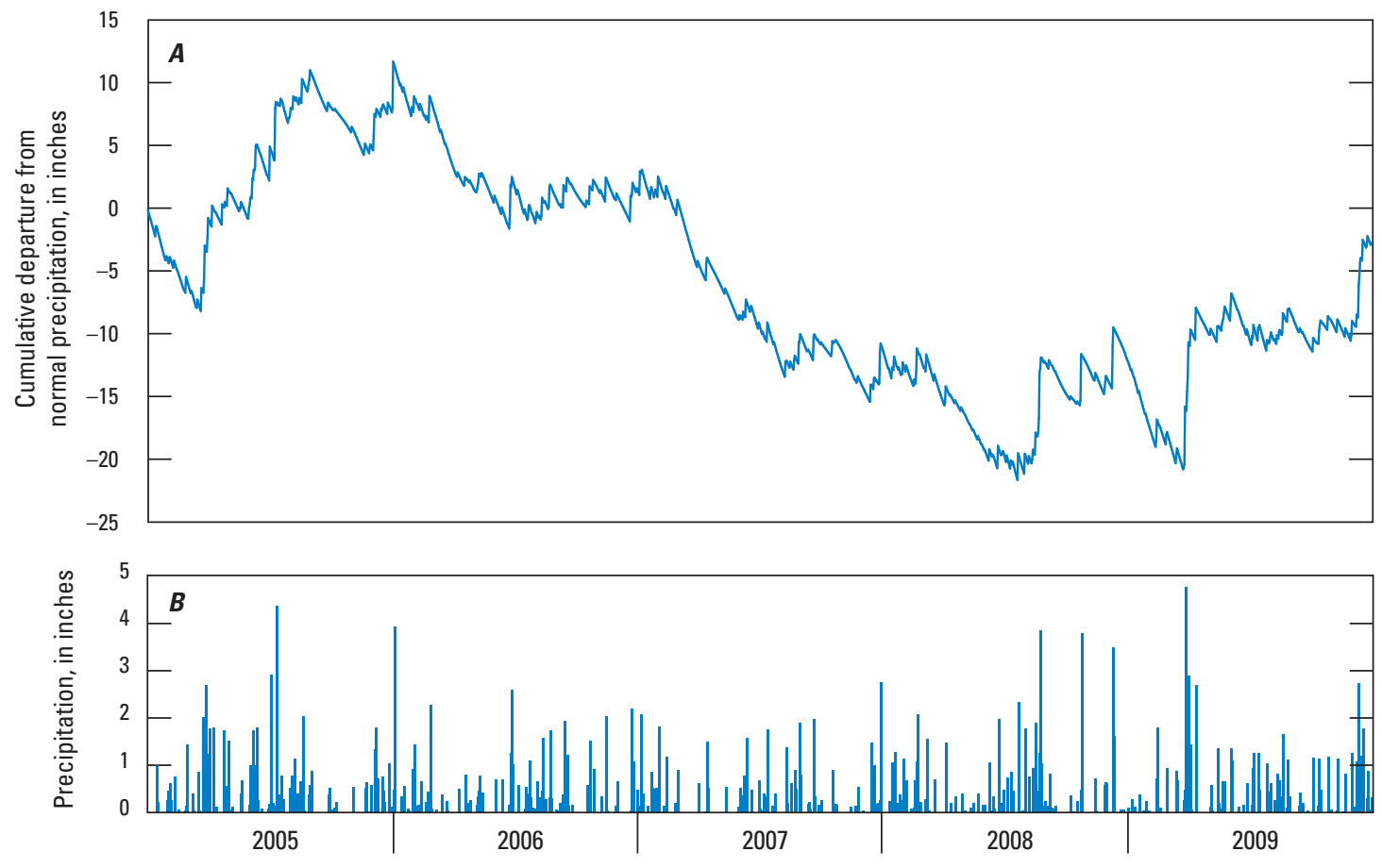

Figure 5. Precipitation data for Albany area, Georgia, January 1, 2005, through December 31, 2009. $A$. Cumulative departure from normal precipitation for National Oceanographic and Atmospheric Administration Site, Albany 3 SE. B. Total daily precipitation for Georgia Automated Environmental Monitoring Network site, Albany State University.

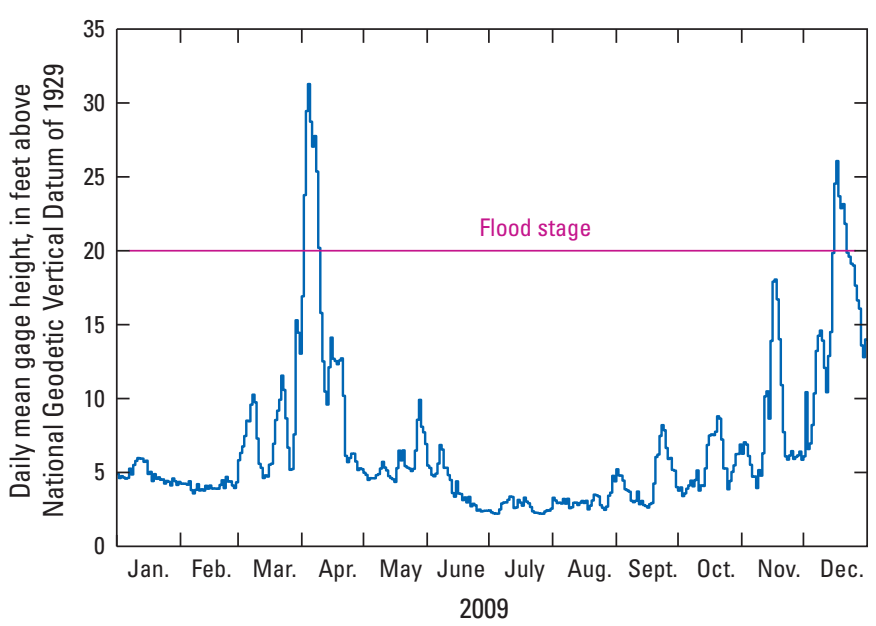

Figure 6. Daily mean gage height for the Flint River at Albany, Georgia (streamgage 02352500), 2009.

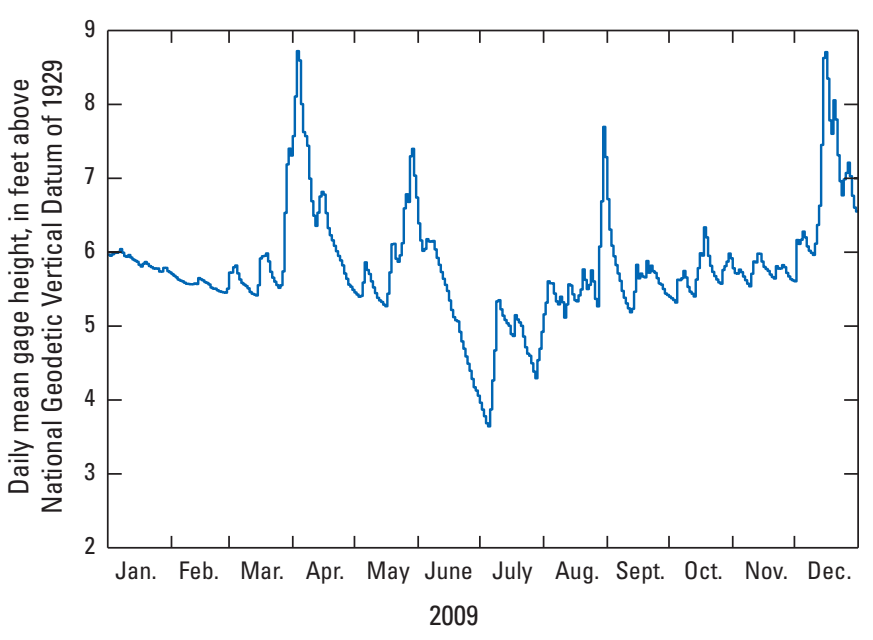

Figure 7. Daily mean gage height for the Chickasawhatchee Creek gage near Leary, Georgia (streamgage 02354410), 2009. 


\section{Groundwater Levels}

Fluctuations and long-term trends in groundwater levels can occur as a result of changes in recharge to, and discharge from, an aquifer. Recharge to an aquifer varies in response to precipitation, evapotranspiration, surface-water infiltration into an aquifer, and regional groundwater inflow. Discharge from an aquifer occurs as natural flow from an aquifer to streams or springs, as evapotranspiration from shallow water-table aquifers, as leakage to vertically adjacent aquifers, as regional outflow, and as withdrawal (pumping) from wells.

\section{Surficial Aquifer}

Water levels in the surficial aquifer are monitored in two wells, 12L371 and 12L376 (table 1; fig. 1), and the hydrographs for these wells represent a compilation of 10 manual measurements each during 2009 (appendix 1, figs. 1-1 and $1-2)$. The relatively low water levels observed in wells 12L371 and 12L376 during January and February 2009 most likely were the result of below-average rainfall. In March and April, water levels increased sharply in response to more than 15 inches of precipitation received between March 28 and April 13, 2009 (fig. 5). Following this rise, water levels declined gradually in response to slightly below-average precipitation and a seasonal increase in evapotranspiration during the summer months.

\section{Upper Floridan Aquifer}

Water levels in the Upper Floridan aquifer are monitored in 15 wells, 14 of which are equipped with continuous recorders (table 1; fig. 1). Hydrographs for these wells are presented in figures 1-3 through 1-17 (appendix 1). Water levels in the Claiborne aquifer are monitored in five wells, three of which are equipped with continuous recorders. Hydrographs for these wells are presented in figures 1-18 through 1-22 (appendix 1). Water levels in the Clayton aquifer are monitored in six wells, all by continuous recorder. The water level in the Providence aquifer is monitored in one well with a continuous recorder.

Period-of-record groundwater level trends were relatively flat in the 14 Upper Floridan aquifer recorder wells, ranging from -0.36 to 0.10 foot per year (ft/yr)(table 1 ; appendix 1 , figs. $1-3$ to $1-10$ and $1-12$ to $1-17)$. Water-level trends were negative in 10 of these wells; rates of decline ranged from -0.03 to $-0.36 \mathrm{ft} / \mathrm{yr}$ and are attributed largely to two droughts during 1998-2002 and 2006-2007. The greatest decline $(-0.36 \mathrm{ft} / \mathrm{yr})$ occurred in well $12 \mathrm{~K} 141$ located in an agricultural area southwest of the WGL well field. Water-level trends were positive in the other four wells; rates of increase ranged from 0.06 to $0.1 \mathrm{ft} / \mathrm{yr}$. In contrast to these declining water-level trends for the respective periods of record, water levels in the Upper Floridan aquifer during 2008 and 2009 increased at rates of 0.86 to $7.33 \mathrm{ft} / \mathrm{yr}$ (table 1) in response to increased precipitation and decreased pumping.
The potentiometric surface of the Upper Floridan aquifer rose between 2008 and 2009, based on water levels measured at 64 wells in the southwestern Albany area during November 2-6, 2009 (fig. 8; Gordon and others, 2010). At the WGL well field, water levels increased by about $10 \mathrm{ft}$ over water levels measured during 2008. Despite this increase, the shape of the potentiometric surface was generally the same as in previous years, because groundwater levels throughout the Albany area exhibited water-level increases of similar magnitude. The potentiometric surface map indicates that groundwater flow is generally from the northwest to the southeast toward the Flint River, with no evidence of a cone of depression at the WGL well field.

\section{Claiborne Aquifer}

Water levels in five monitor wells completed in the Claiborne aquifer (table 1; fig. 1) indicate response to precipitation and nearby pumping. Period-of-record hydrographs for the three continuously monitored wells (appendix 1, figs. 1-18 to 1-20) depict an overall rise in water-level trends in wells 12L019 (0.40 ft/yr) and 13L011 (0.12 ft/yr) and a declining trend in well 13L015 ( $-0.51 \mathrm{ft} / \mathrm{yr})$. Specifically, water levels generally rose during 2003-2006, corresponding to increased precipitation, and declined during 2006-2007 in response to drought. During 2008-2009, water levels increased in wells 12L019 (3.79 ft/yr) and 13L011 (2.63 ft/yr), most likely in response to increased precipitation, and declined in well 13L015 (-0.92 ft/yr), possibly in response to nearby pumping.

\section{Clayton and Providence Aquifers}

Water levels in six wells completed in the Clayton aquifer and in one well completed in the Providence aquifer (table 1; fig. 1) have responded during their respective periods of record to nearby pumping variations (to meet fluctuating irrigation demand) and to changes in precipitation. During 2008-2009, water levels increased in Clayton aquifer wells $11 \mathrm{~K} 005$, 11L002, 12M002, and 13L002 (appendix 1, figs. 1-23, 1-24, $1-26$, and 1-27) at rates of 0.32 to $5.25 \mathrm{ft} / \mathrm{yr}$; water levels declined in wells 12L020 and 13L013 at rates of -1.98 and $-4.01 \mathrm{ft} / \mathrm{yr}$, respectively (appendix 1, figs. 1-25 and 1-28). Period-of-record groundwater data for wells 12L20 and 13L013 indicate long-term increases of 0.32 and $0.07 \mathrm{ft} / \mathrm{yr}$, respectively; and long-term declines for wells $11 \mathrm{~K} 005$, 11L002, 12M002, and 13L002 ranging from -1.79 to $-0.73 \mathrm{ft} / \mathrm{yr}$ (appendix 1, figs. 1-23, 1-24, 1-26, and 1-27). Most of these declines occurred during (1) periods of increased water withdrawal, prior to the $1980 \mathrm{~s}$, in response to increased municipal, industrial, and irrigation pumping, and (2) during the mid-1980s and mid-1990s to 2002 in response to increased irrigation demand resulting from decreased precipitation and increased agricultural production. During the period of record, water levels also showed periods of recovery in response to decreased water withdrawals, perhaps the result of water-conservation measures initiated by farmers. In some areas, water levels in the Clayton aquifer appear to have stabilized since the 1980s (appendix 1, 12L020 in fig. 1-25 and 13L013 in fig. 1-28). 
To keep the Clayton aquifer a viable resource, the Georgia Environmental Protection Division (GaEPD) imposed a moratorium on new permits in the early 1990s for wells completed in the Clayton aquifer, and thus slowed the increase in groundwater withdrawals during subsequent years (Georgia Department of Natural Resources Environmental Protection Division, 2001). Water levels rose in the aquifer during 2002-2004 and 2008-2009 in response to increased precipitation and decreased irrigation-water demand.
Water levels in Providence aquifer well 12L021 showed little long-term change during the period of record (table 1; appendix 1, fig. 1-29). Water-level declines caused by the 1980s and 1990s droughts and increased pumping were offset by a pronounced water-level increase beginning in 2003 that corresponded to increased precipitation and decreased pumping, resulting in little net change during the period of record. During 2008 and 2009, water levels increased at a rate of $1.57 \mathrm{ft} / \mathrm{yr}$, continuing the upward trend that began in 2003 .

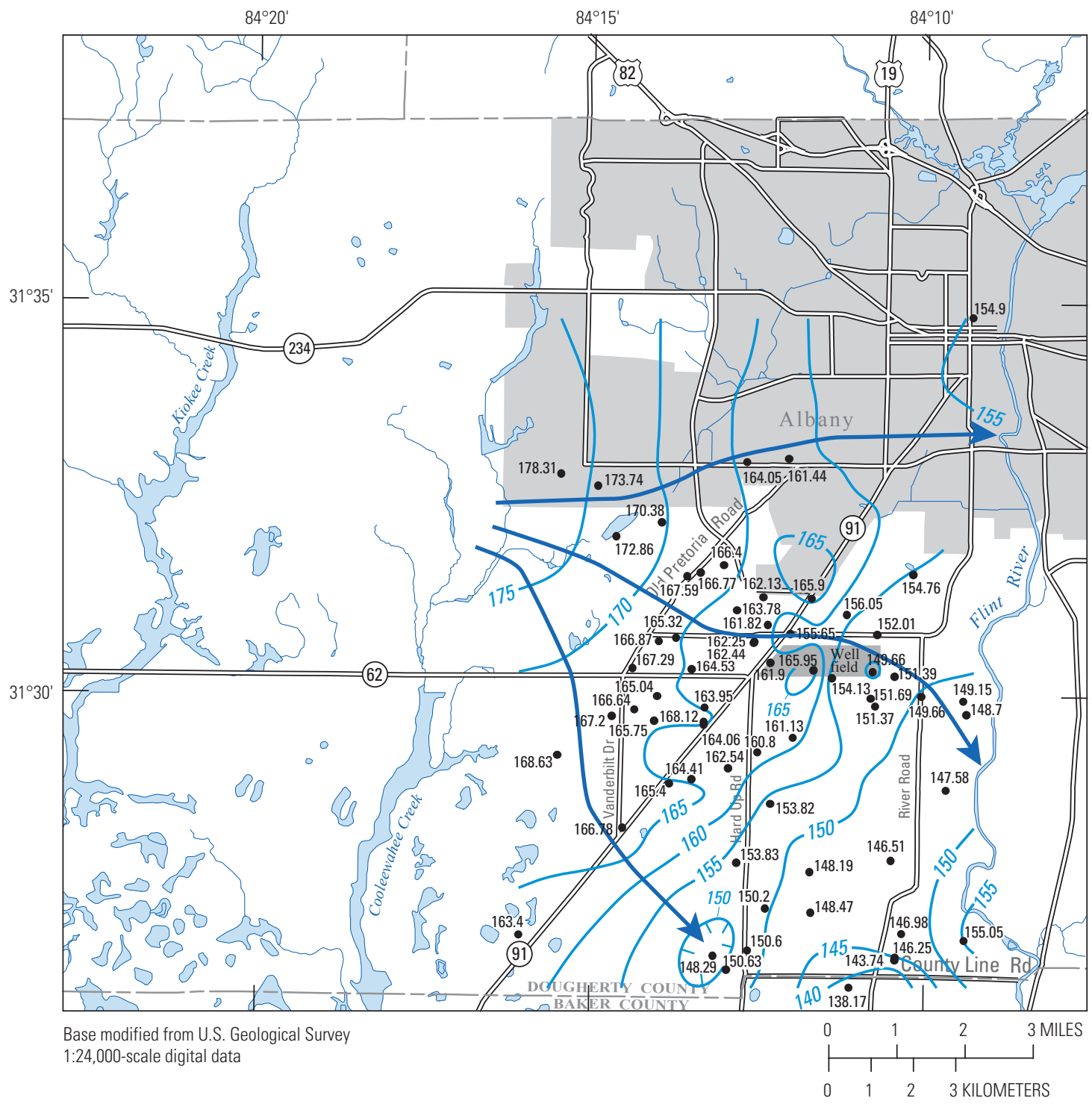

EXPLANATION

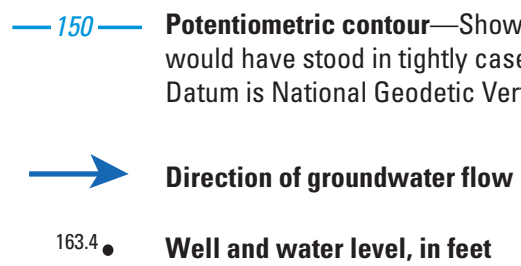

Figure 8. Potentiometric surface of the Upper Floridan aquifer in the Albany area of Dougherty County, Georgia, November 2-6, 2009. 


\section{Sinkhole Monitoring}

Sinkholes formed at the WGL well field before and after the initiation of well-field pumping in October 2003 (figs. 9 and 10). A condition of the water-withdrawal permit for the WGL well field is to report existing, new, or developing sinkholes to GaEPD on a quarterly basis (William Frechette, Georgia Environmental Protection Division, written commun., May 18, 2009).
The WGL personnel record each sinkhole that develops on the well-field property and submit a written report to GaEPD each quarter. Six new sinkholes formed at the WGL well field during 2009 (Jim Stolze, Albany Water, Gas, and Light Commission, written commun., March 31 and June 30, 2009). To evaluate possible causes of sinkhole formation at the WGL well field, the USGS investigated the relation between groundwater levels and subsurface cavernous zones during 2009 , as described later.
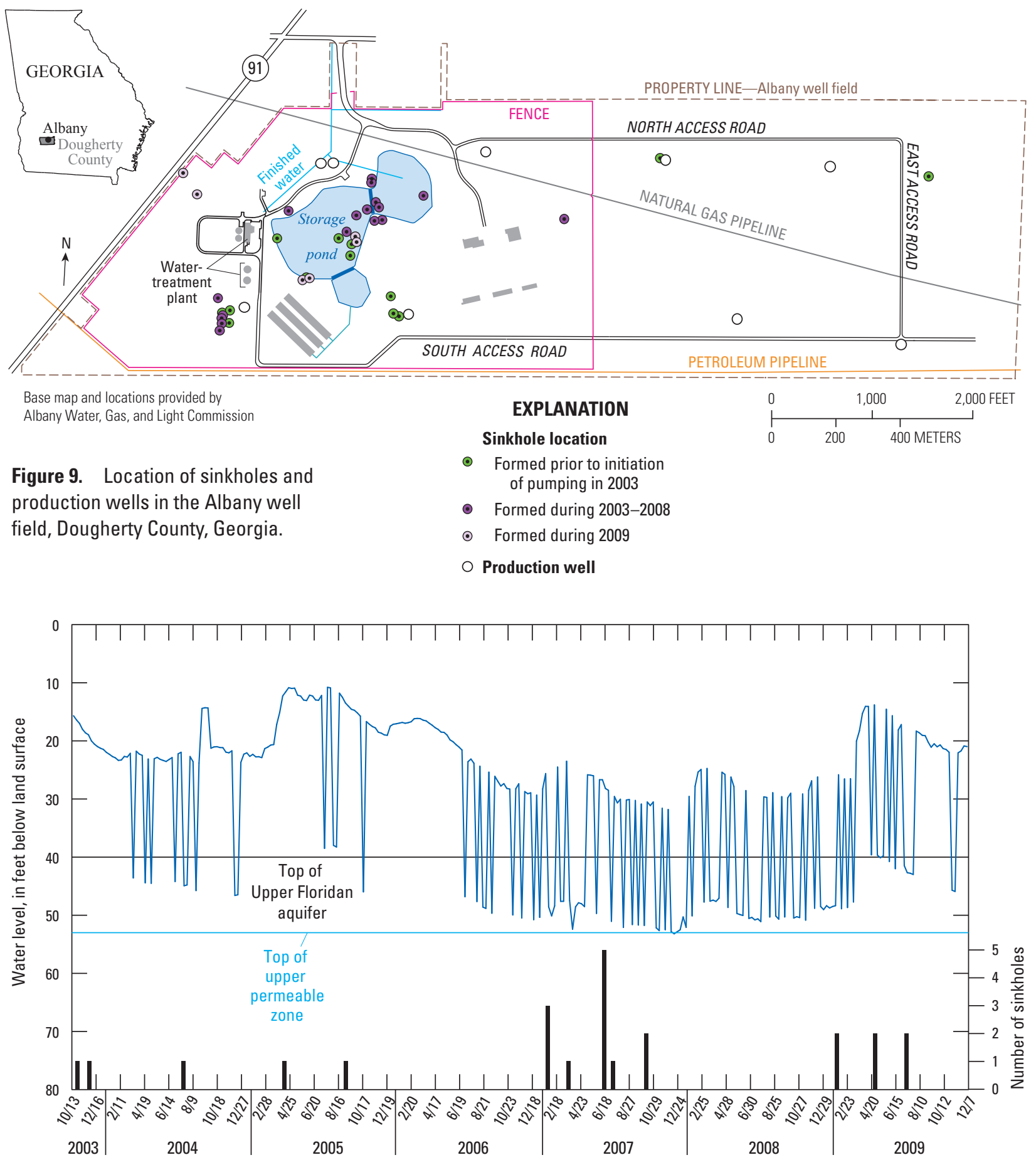

Figure 10. The number of sinkholes that formed in the Albany well field, daily depth to water in well 12L382, and the depth to the top of the Upper Floridan aquifer at well 12L382, October 2003-December 2009. 


\section{Groundwater Quality}

As part of the Cooperative Water Program, water samples are collected annually during the fall, from the Flint River, surficial aquifer, and Upper Floridan aquifer near the WGL well field, and analyzed for nitrate and other major nutrients associated with infiltration from urban, rural, and agricultural sources. Water samples are also collected from a public-supply well completed in the Claiborne and Clayton aquifers in the northern part of Albany and analyzed for pesticides that have the potential to migrate to the well from a nearby hazardous-waste site.

\section{Upper Floridan and Surficial Aquifers}

Nitrate concentrations in water samples collected from 12 Upper Floridan aquifer wells and 1 surficial aquifer well near the WGL well field during November 3-6, 2009, ranged from 2.0 to $13.3 \mathrm{mg} / \mathrm{L}$ (table 2; figs. 11 and 12; appendix 3). The nitrate concentration in the water sample from Upper Floridan aquifer well $12 \mathrm{~L} 061$ totaled $12.9 \mathrm{mg} / \mathrm{L}$, exceeding the $10 \mathrm{mg} / \mathrm{L}$ MCL. This value represents a $0.4-\mathrm{mg} / \mathrm{L}$ increase from the November 2008 nitrate concentration, but a lower nitrate concentration than obtained during 2003-2005, when nitrate concentrations ranged from 13.1 to $13.7 \mathrm{mg} / \mathrm{L}$. The nitrate concentration in water from surficial aquifer well 12L376 also exceeded the $10 \mathrm{mg} / \mathrm{L} \mathrm{MCL}$, with a concentration of $13.3 \mathrm{mg} / \mathrm{L}$ in November 2009, a 3.2-mg/L increase from 2008. Overall, nitrate concentrations appear to be increasing slightly (fig. 12). Nitrate concentrations increased slightly in nine wells and decreased in three wells. One well sampled in 2009 was not sampled in 2008. The greatest increases were in Upper Floridan aquifer well 12L340 $(2.6 \mathrm{mg} / \mathrm{L})$ and surficial aquifer well $12 \mathrm{~L} 376(3.2 \mathrm{mg} / \mathrm{L})$. During the same period, concentrations decreased in Upper Floridan aquifer well 12L350 by $3.2 \mathrm{mg} / \mathrm{L}$. Nitrate concentrations in most wells typically increase in wet years and decrease in dry years; however, concentrations in well 12L350 show the opposite effect. A borehole video survey was conducted to assess whether a breach in the well casing might be the cause of this anomalous pattern. Results of the survey indicated no problems with well construction, and the cause of the anomalous response remains unresolved.

Water-chemistry data from samples collected from the Flint River on November 4, 2009 (station 02352560, fig. 1), and samples collected from wells in the WGL well field area were compared to assess the potential for surface-water capture by the well field. A trilinear diagram showing the percent composition of selected major cations and anions (fig. 13) indicates distinctly different chemical constituents in water samples from the Upper Floridan aquifer compared with samples from the Flint River. Water from the Upper Floridan aquifer exhibits supersaturation of calcium, in contrast to the sodium-potassium-magnesium-type water from the Flint River. This dichotomy of water chemistry between samples collected from the Upper Floridan aquifer and Flint River during 2009 suggests that groundwater from the well field appears not to be mixing with water from the Flint River, and is consistent with similar water-chemistry contrasts observed in samples collected and analyzed during 2003-2008 (Gordon, 2009).

\section{Claiborne and Clayton Aquifers}

Production-well susceptibility to constituents of concern - In 1989, the U.S. Environmental Protection Agency (USEPA) added the THAN hazardous waste site in northern Dougherty County to the National Priorities List (U.S. Environmental Protection Agency, 2003). The site consists of two facilities that processed various liquid and dry formulations of pesticides and other chemical compounds from the 1950s until 1982. Organochlorine pesticides are the primary constituents of concern (U.S. Environmental Protection Agency, written commun., 2003) for potential contamination by offsite, subsurface migration into soils and groundwater at the production wells. In 2007, concentrations in groundwater exceeded the 2008 health-based criteria for 1, 2-dibromoethane, aldrin, alpha-BHC (an alpha isomer of benzene hexachloride), beta-BHC (a beta isomer of benzene hexachloride), 4,4'-dichlorodiphenyltrichloroethane (DDT), dieldrin, toxaphene, and xylene (U.S. Environmental Protection Agency, written commun., 2008). The site is located within 1.5 to 2 miles (mi) of two WGL production wells open to the Claiborne and Clayton aquifers in the northern Albany area (wells 12L010 and 12L018; fig. 11). Water samples collected from supply wells 12L010 and 12L018, completed in both the Claiborne and Clayton aquifers in the northern part of Albany were used to detect the presence of contaminants that might have migrated from the site (fig. 11; U.S. Environmental Protection Agency, 2006).

USEPA-related monitoring and findings - In May 2008, a 66-ft-deep well completed in the Upper Floridan aquifer at the THAN site contained 20 micrograms per liter $(\mu \mathrm{g} / \mathrm{L})$ of toxaphene (U.S. Environmental Protection Agency, written commun., 2008), which represents about seven times the MCL of toxaphene (3 parts per billion; U.S. Environmental Protection Agency, 2011). According to the USEPA, sample analysis indicates that toxaphene concentrations have been increasing in downgradient, perimeter, and offsite shallow wells completed in the Upper Floridan aquifer since 2003 (U.S. Environmental Protection Agency, September 2008). Evidence of vertical contaminant migration into deeper water-bearing units of the Upper Floridan aquifer also exists (U.S. Environmental Protection Agency, written commun., September 2008). There currently are no data reported by the USEPA demonstrating the migration of contaminants into the Claiborne and Clayton aquifers at the THAN site.

USGS-related monitoring and findings-Although there are no data demonstrating migration of contaminants into the Claiborne and Clayton aquifers at the hazardous waste site, as a precaution, USGS collected water samples from the two nearest production wells completed in these aquifers downgradient of the THAN site. During 2008, water samples were collected from WGL production wells 12L010 and 12L018 (fig. 11) and analyzed for several pesticide compounds reported at the site. 


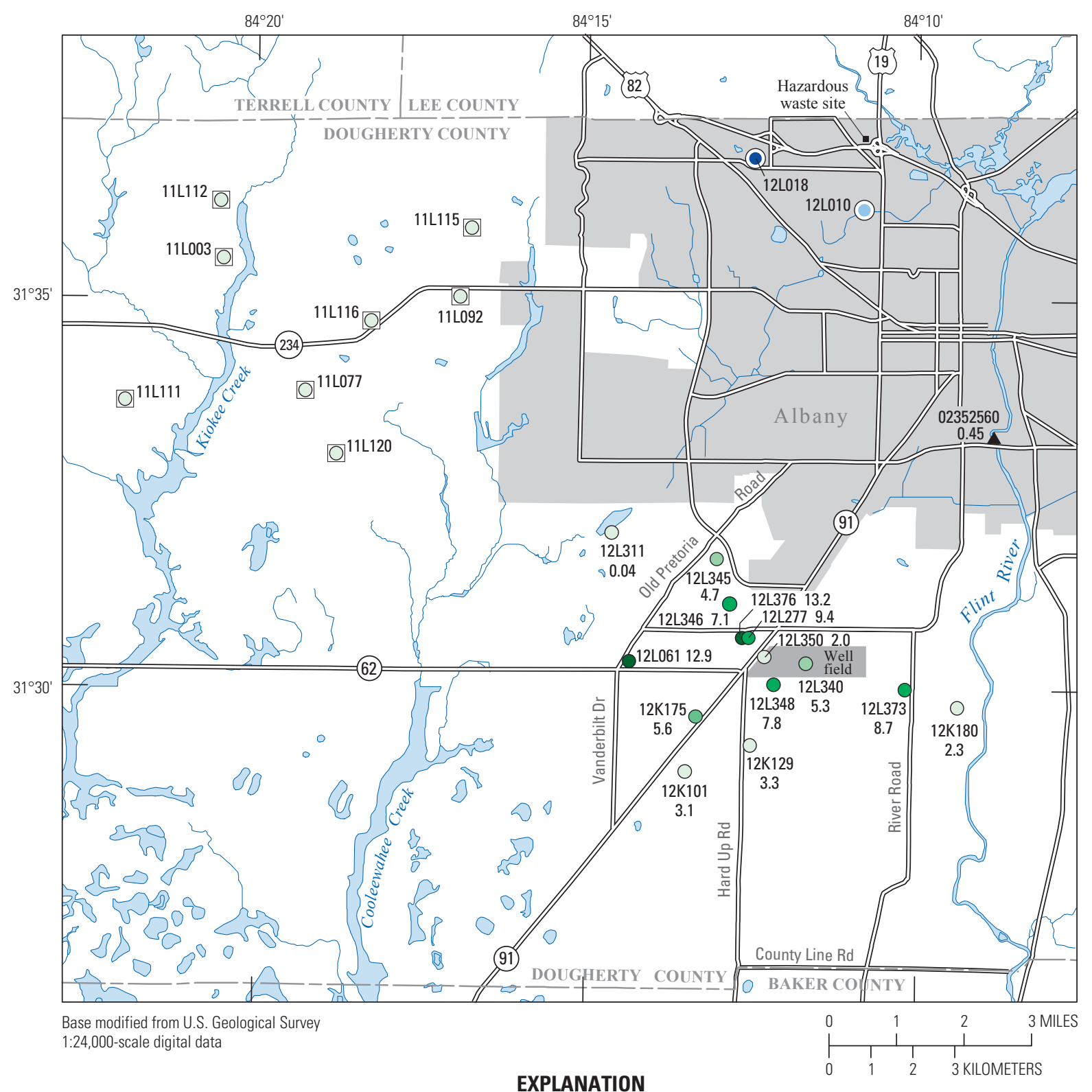

EXPLANATION

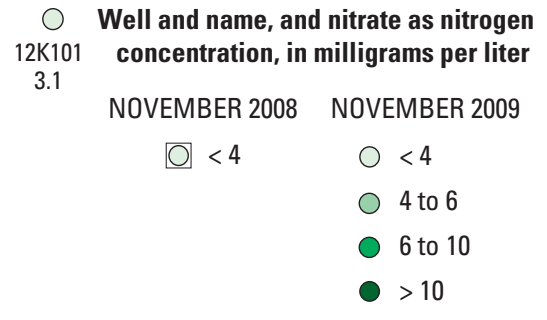
Well tested for pesticide, November
() 2008 and 2009
(-) 2008 only

Surface-water site and nitrate as nitrogen concentration, in milligrams per liter, November 2009 02352560 0.45

Figure 11. Nitrate concentrations in the Upper Floridan aquifer and surficial aquifer, 2008 and 2009, and wells tested for pesticides during 2008 and 2009, Albany area, Georgia. All wells completed in Upper Floridan aquifer except for well 12L376, which is completed in the surficial aquifer, and wells $12 \mathrm{~L} 018$ and 12L010, which are completed in the Claiborne and Clayton aquifers, respectively. 


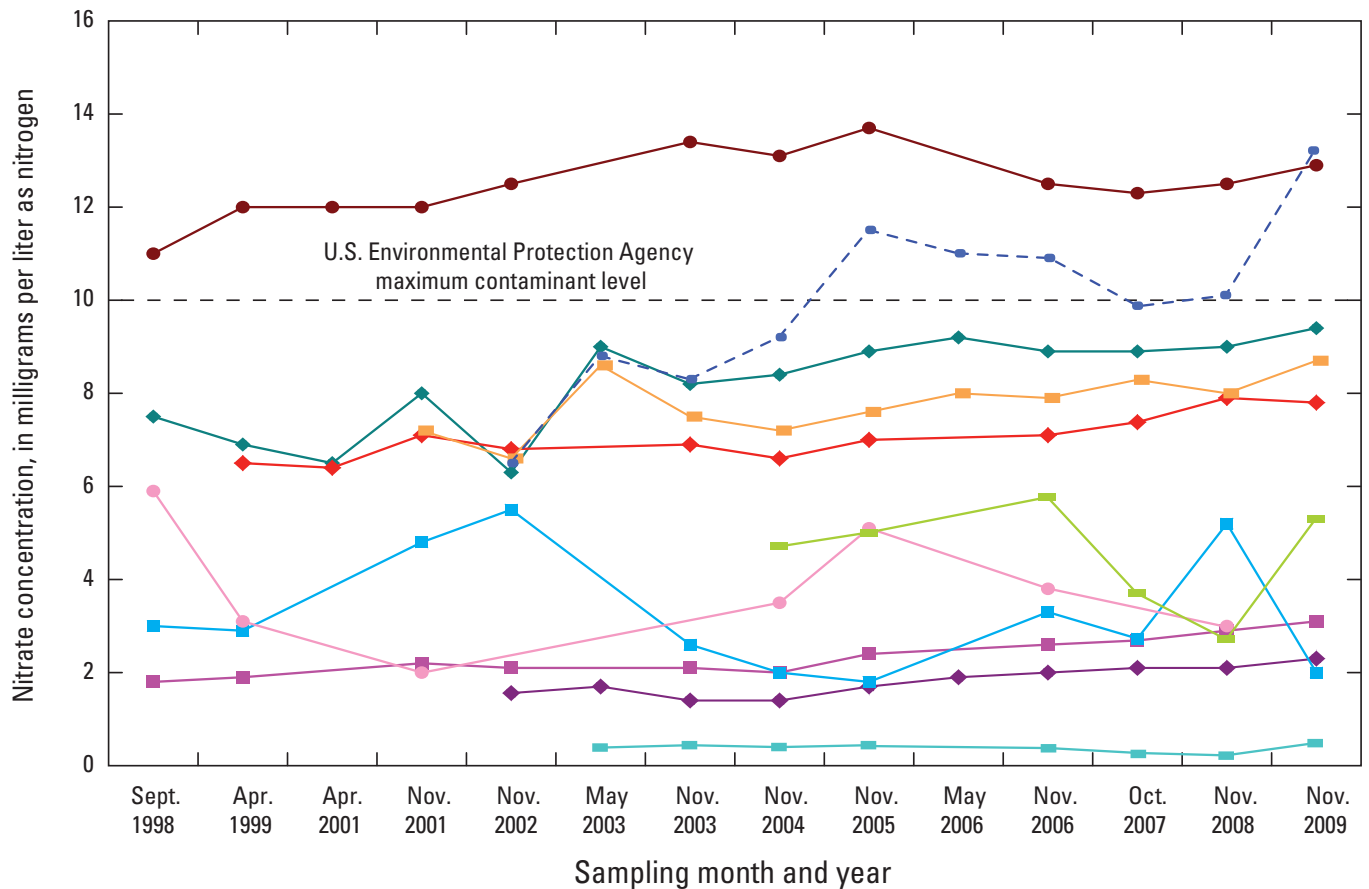

EXPLANATION

Upper Floridan aquifer well

$\longrightarrow$ 12L061

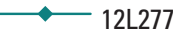

$\longrightarrow 12 \mathrm{~L} 373$

$\longrightarrow 12 \mathrm{~L} 348$

$=12 \mathrm{~L} 340$

$\longrightarrow 12 \mathrm{~L} 357$

$\longrightarrow 12 \mathrm{~L} 350$

$\longrightarrow$ 12K101

$\longrightarrow$ 12K180

Surficial

aquifer well

- - - - 12L376

Flint River streamgage

Figure 12. Nitrate concentrations in selected wells and the Flint River at Albany, Georgia, September 1998-November 2009.

Figure 13. Trilinear diagram showing water chemistry of the Upper Floridan aquifer and the Flint River at station 02352560 in the Albany area of Dougherty County, Georgia, November 2009.

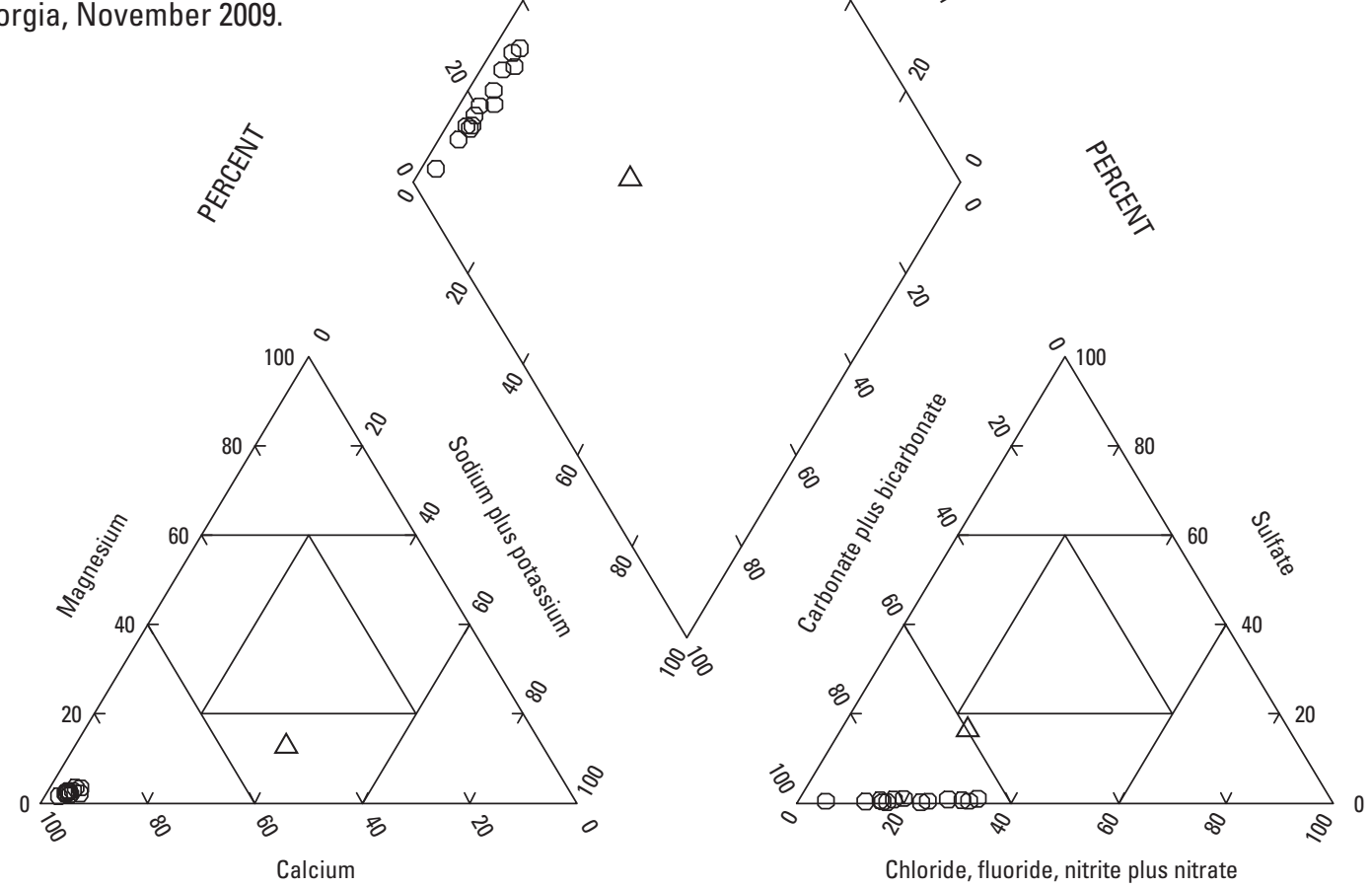




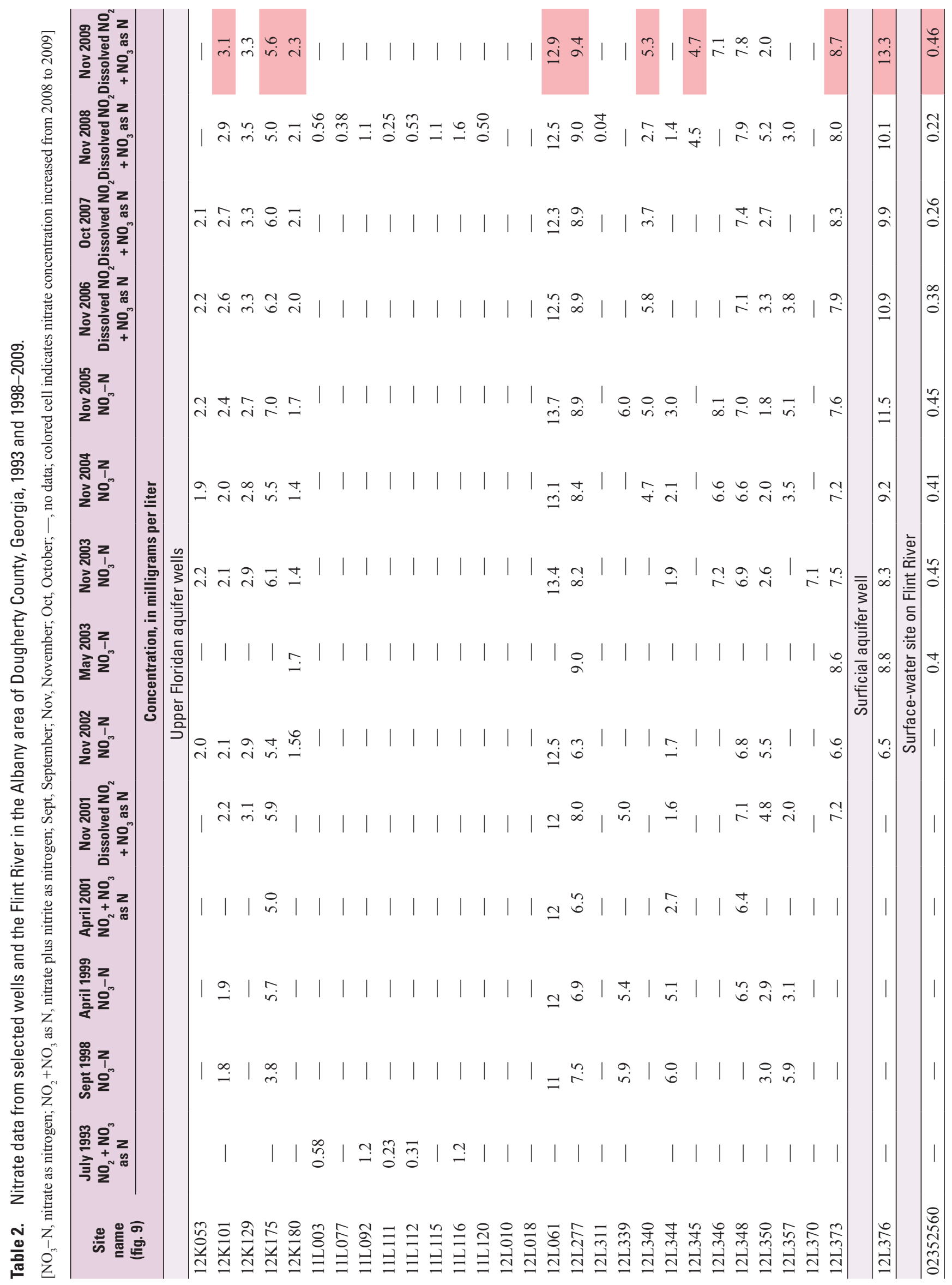


The sample from well 12L010 contained no detectable pesticides, and the sample from well 12L018 contained p,p'methoxychlor (a degradation product of DDT) in very low concentration $(0.0014 \mu \mathrm{g} / \mathrm{L})$, below the reporting limit and four orders of magnitude below the MCL of $40 \mu \mathrm{g} / \mathrm{L}$ (U.S. Environmental Protection Agency, 2000). Although the reported concentration is not cause for concern, well 12L018 was resampled in November 2009, and pesticides were not detected.

\section{Analysis of Sinkhole Formation}

During 2009, the USGS performed groundwater studies to evaluate the occurrence of sinkhole formation in the WGL well field. Sinkholes commonly form naturally in areas underlain by shallow carbonate aquifers like the Upper Floridan. The development of land and groundwater resources in these areas can increase the frequency of sinkhole formation (Tihansky, 1999). Sinkholes can cause property damage and structural problems, and they can create pathways for surface contaminants to enter and degrade the groundwater resources (Tihansky, 1999).

Sinkholes form when materials collapse into underlying voids in bedrock. Slightly acidic rainwater percolates vertically into the carbonate rocks through joints and fractures and dissolves the rock, resulting in the development of larger voids. When these dissolution features are filled with water, the roof of the void is supported by the hydrostatic pressure the water provides. When water levels decline below the roof of the cavity and hydrostatic support is removed, sinkholes often develop as the roof collapses and overburden sediments fall into these cavities. Consequently, more sinkholes form in karst areas when groundwater levels are low than when they are high (Wilson and Beck, 1992; Tihansky, 1999).

Pumping variations may cause local, rapid groundwater fluctuations that may cause many sinkholes to develop quickly (Tihansky, 1999). For example, the pumping rate was tripled at a well field north of Tampa, Florida (Fla.) in 1964, and 64 sinkholes formed in less than a month within a 1-mi radius of the well field (Tihansky, 1999). Wilson and Beck (1992) demonstrated the relation between drawdown and sinkhole formation by comparing the frequency of reported sinkhole collapses at any given water level to the frequency of occurrence for that water level. They found that sinkholes were 10 times more likely to form when water levels were $10 \mathrm{ft}$ below the mode (the most frequently measured water level) in the Orlando, Fla., area. Wilson and Beck (1992) also concluded that, "[managing] consumptive water use to avoid excessive drawdowns in the high recharge areas would minimize sinkhole development induced by human activities."

Sinkhole formation has been an ongoing problem at the WGL well field. More than 23 sinkholes have developed in the well-field area since the initiation of pumping in October 2003 (figs. 9 and 10). In addition to pumping-induced water-level fluctuations, sinkhole formation may be associated with three ponds that were excavated 9-14 $\mathrm{ft}$ into the undifferentiated overburden in the west-central part of the WGL well field. Many of the sinkholes have formed in and adjacent to the ponds following construction. In a literature review by Langer (2001), several types of construction-induced sinkholes are presented, including overburden removal. Excavating soil cover during overburden removal may thin the roof of a soil cavity or remove clay soil that was sealing underlying sand, causing cavity failure or collapse (Langer, 2001).

Groundwater-level fluctuations relative to the top of the Upper Floridan aquifer seem to contribute to sinkhole formation in the WGL well field. Higher frequency groundwaterlevel fluctuations about the top of the Upper Floridan aquifer since 2006 seem to coincide with a higher frequency of sinkhole formation, compared with pre-2006 water-level fluctuations and sinkhole formation (fig. 10). This association of sinkhole formation with the frequency of changes in water levels relative to the top of the limestone aquifer could explain the occurrence of voids in the limestone near the top of the aquifer. Rapid water-level decline may cause cavity roof material to collapse if this material and (or) underlying voids become unsaturated (Tihansky, 1999).

During October 2003-December 2009, water levels in well 12L382 fluctuated from a depth of about $10.8 \mathrm{ft}$ (during nonpumping) to $53.2 \mathrm{ft}$ (during pumping) below land surface, with an average depth of about $29.7 \mathrm{ft}$. A comparison of water levels in well 12L382 during October 2003-December 2009 to (1) depths to the top of the Upper Floridan aquifer and top of the upper permeable zone and (2) sinkhole formation frequency, indicates that most of the sinkholes at the WGL well field (17 of 23) formed between early 2007 and late 2009 when the water level in well 12L382 oscillated above and below the top of the aquifer on a regular basis (fig. 10). Water levels did not fluctuate below the top of the upper permeable zone. Two sinkholes formed during 2003 and 2005, when water levels stood almost $20 \mathrm{ft}$ above the top of the aquifer throughout most of the year. No sinkholes formed during 2008 , even though water levels and pumping patterns were similar to those during 2007.

Although sinkhole formation at the WGL well field is not completely understood, the preceding analysis indicates that sinkhole formation appears to be more frequent when the water level in the Upper Floridan aquifer rapidly oscillates above and below the top of the aquifer than when water-level oscillations are less frequent. As suggested in west-central Florida (Tihansky, 1999), it may be possible to reduce the number of new sinkholes by altering pumping at the WGL well field to control groundwater-level fluctuations.

A three-dimensional geologic diagram was created using the geographic information system software ArcScene ${ }^{\mathrm{TM}}$ from data indicating depths to hydrologic units and high-permeability zones determined from borehole geophysics (fig. 14). Caliper, natural gamma, fluid resistivity, conductivity, and temperature logs collected during the construction of production wells in the WGL well field indicate two zones of high secondary permeability (dissolution features) within the Upper Floridan aquifer ranging from 26 to $66 \mathrm{ft}$ above NGVD 29 (125-170 ft below 
Figure 14. Threedimensional geologic diagram of the well field in the Albany area of Dougherty County, Georgia. Space was added between each layer for visibility.

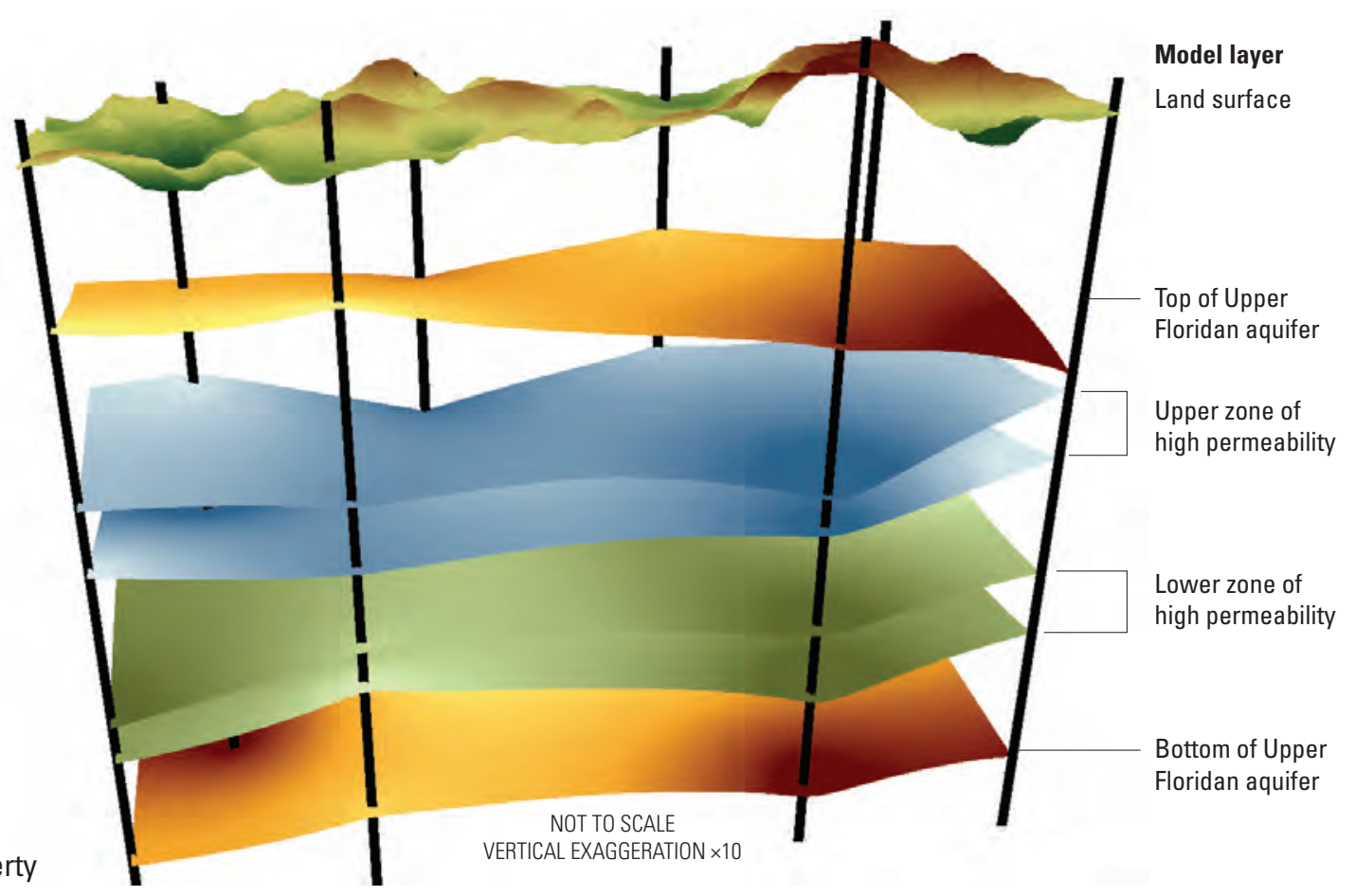

EXPLANATION

[Datum is National Geodetic Vertical Datum of 1929]
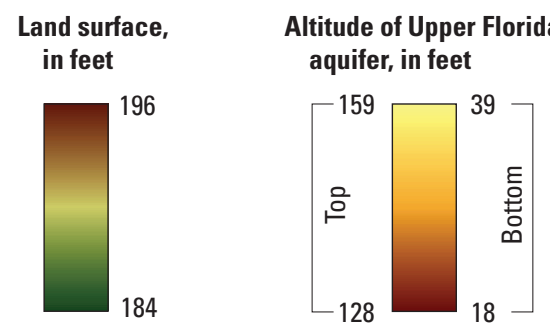

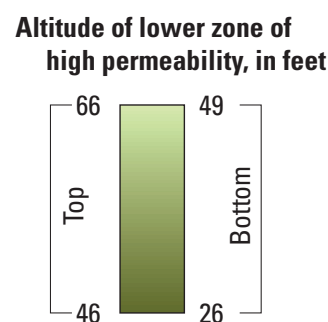

land surface) and from 71 to $106 \mathrm{ft}$ above NGVD 29 (106-114 ft below land surface). Similar zones of high secondary permeability were reported for the Upper Floridan aquifer in wells located about 2 mi southwest of the WGL well field (Warner, 1997). Maps prepared for the period of frequent sinkhole formation-February 5, 2007, to December 14, 2009-show groundwater levels relative to the top of the Upper Floridan aquifer, wells that were pumping, and locations of sinkholes that formed (fig. 15). Groundwater levels remained above the top of the upper permeable zone of the aquifer during the entire period. Sinkholes formed at the WGL well field, however, when water levels stood above and below the top of the aquifer.

On February 5, 2007, three sinkholes formed in the western part of the WGL well field when water levels stood above the top of the aquifer (fig. 15). On March 12, 2007, one sinkhole formed in the same general area; however, a well was pumping nearby, and water levels declined below the top of the aquifer. On June 26, 2007, another sinkhole formed in the area when water levels increased above the top of the aquifer. Two more sinkholes formed in the same area on October 15, 2007, while two nearby wells were pumping, and groundwater levels declined to more than $10 \mathrm{ft}$ below the top of the aquifer. No new sinkholes formed at the WGL well field during 2008, even though water-level fluctuations were similar to water-level fluctuations that occurred during 2007. On January 12, 2009, two sinkholes formed in the west-central part of the WGL well field while a nearby well was pumping, and water levels declined below the top of the aquifer. On April 26, 2009 and July 6, 2009, two sinkholes formed in the western and southwestern areas of the WGL well field, respectively, where water levels stood above the top of the aquifer. Although sinkhole development does not appear to coincide directly with well-field pumping and Upper Floridan aquifer water levels, indirect relations suggesting a time delay between well-field pumping and sinkhole formation may be established at a later time based on water-level and sinkholeformation data that continue to be collected.

All of the sinkholes that formed during 2007 and 2008 have developed in or adjacent to the storage ponds (fig. 15). Ongoing groundwater-level monitoring and the addition of pond stage data may provide more insight into the relation between sinkhole development and water levels. 

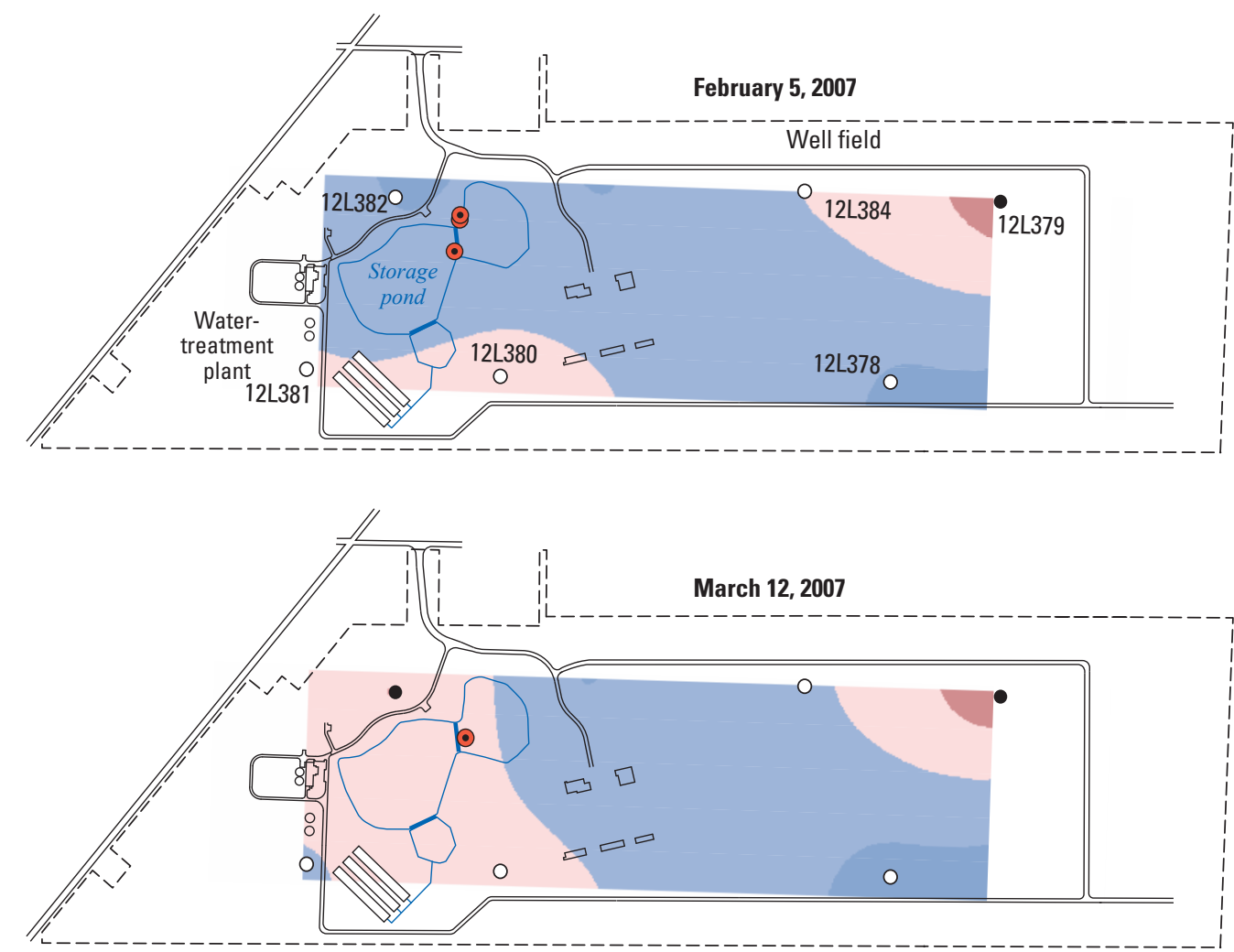

\section{EXPLANATION}

Water level, in feet, above or below top of Upper Floridan aquiferTop of Upper Floridan aquifer is indicated as zero

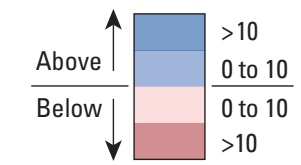

Production well O Not pumping $\bullet$ Pumping

๑ Sinkhole
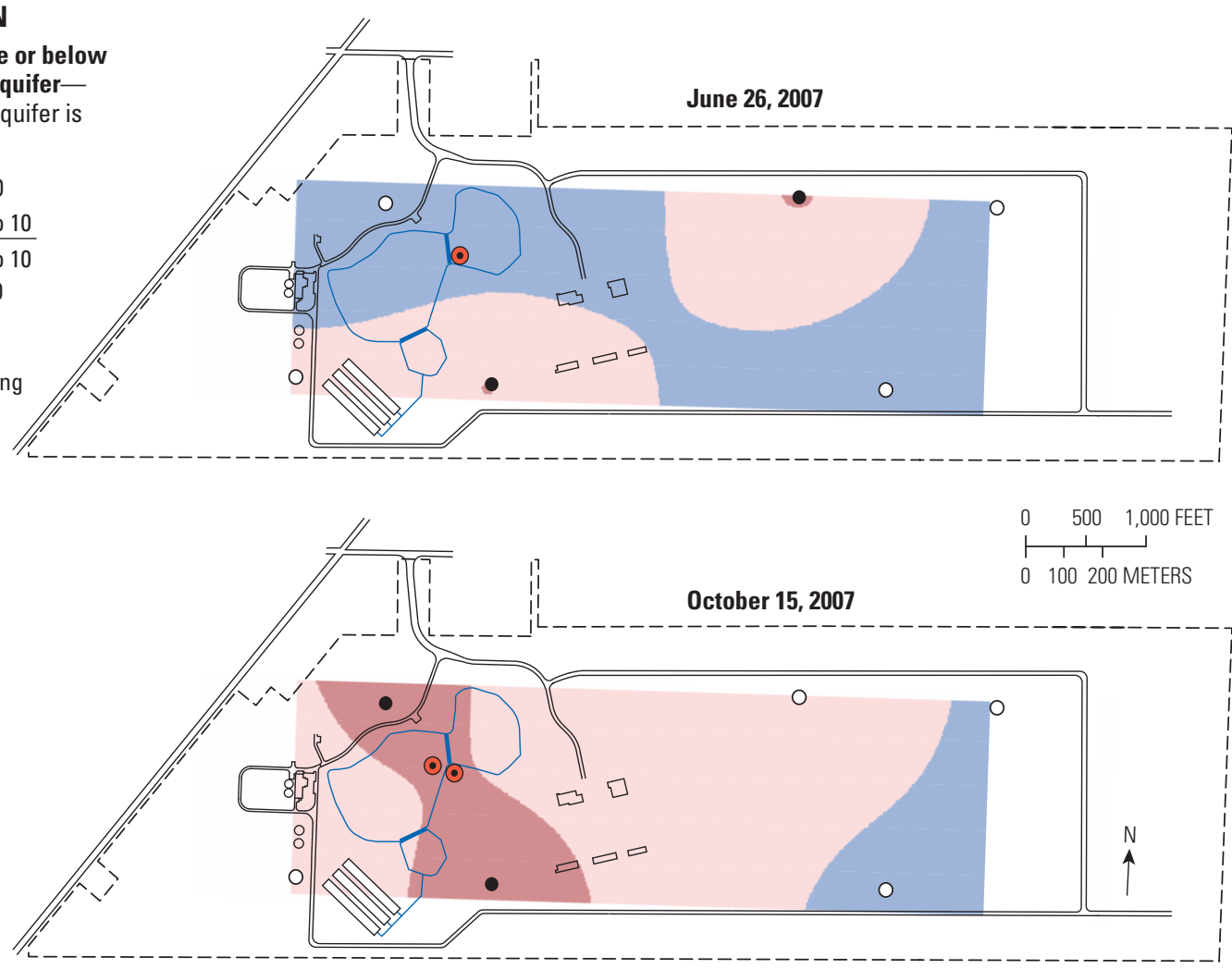

Figure 15. Potentiometric surface of the Upper Floridan aquifer relative to the top of the Upper Floridan aquifer for selected periods at the Albany well field, February 5, 2007, through December 14, 2009. 

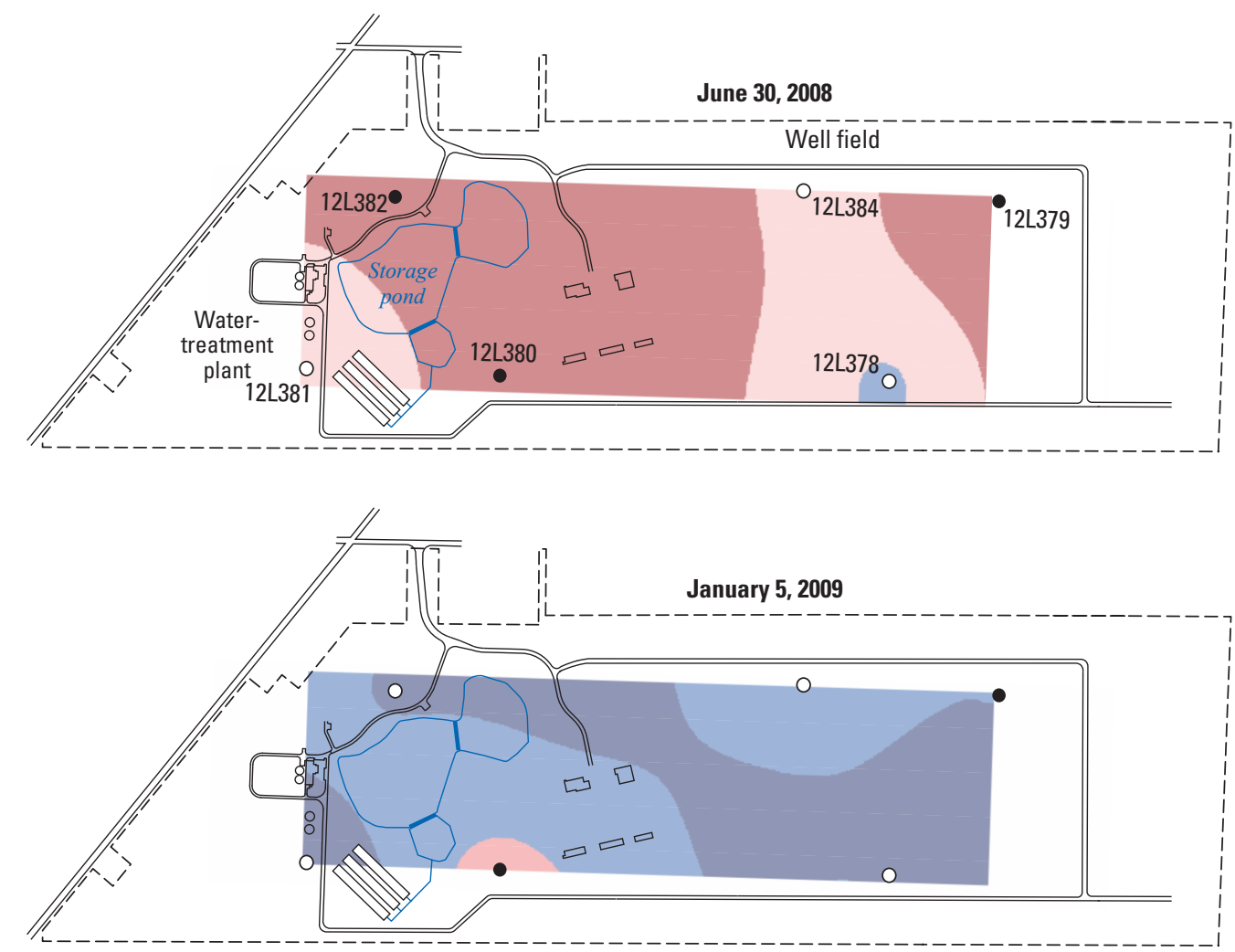

\section{EXPLANATION}

Water level, in feet, above or below top of Upper Floridan aquiferTop of Upper Floridan aquifer is indicated as zero

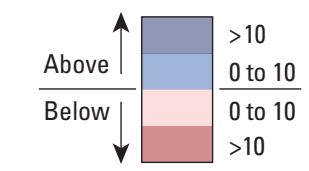

Production well O Not pumping • Pumping

๑ Sinkhole
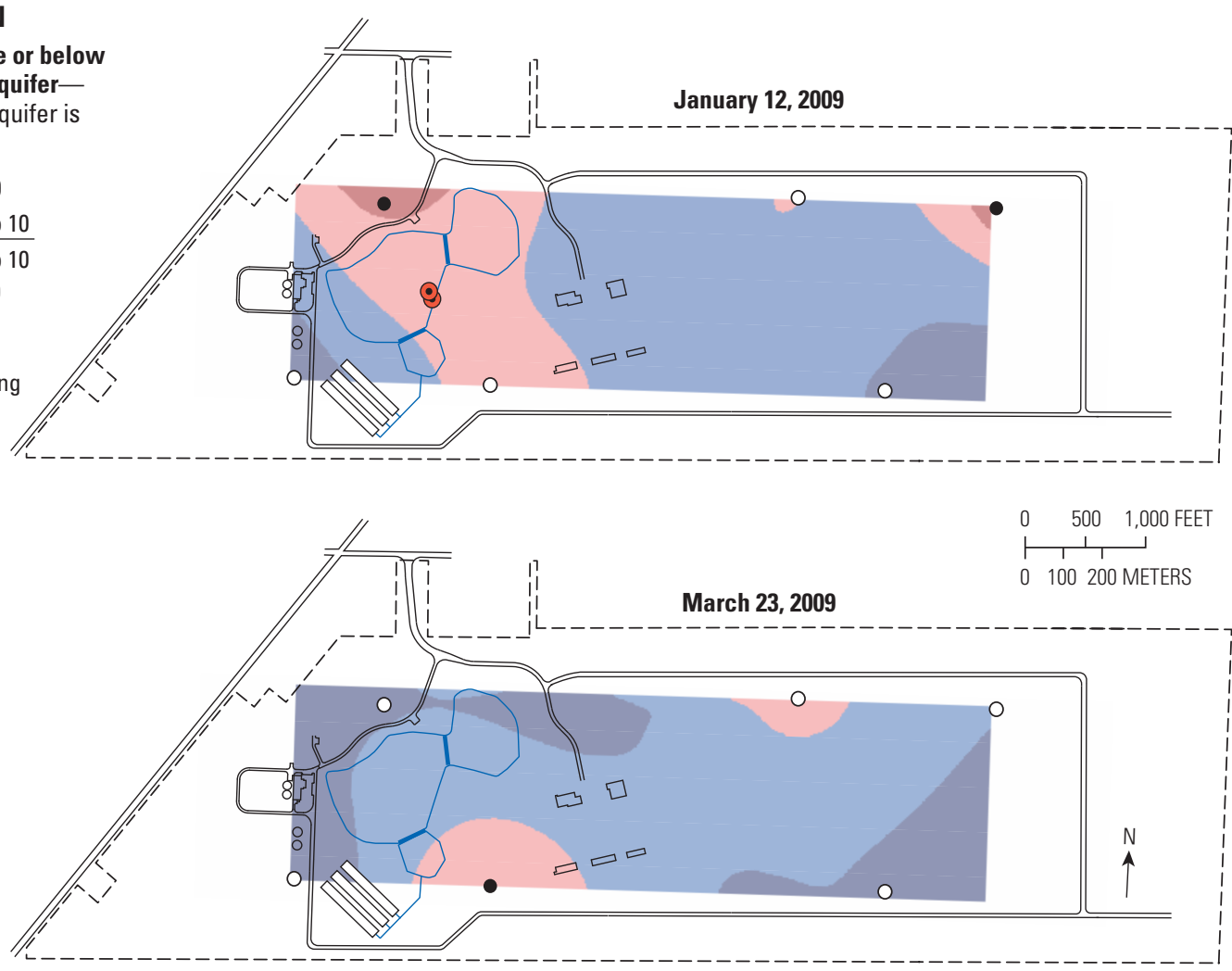

Figure 15. Potentiometric surface of the Upper Floridan aquifer relative to the top of the Upper Floridan aquifer for selected periods at the Albany well field, February 5, 2007, through December 14, 2009._Continued 

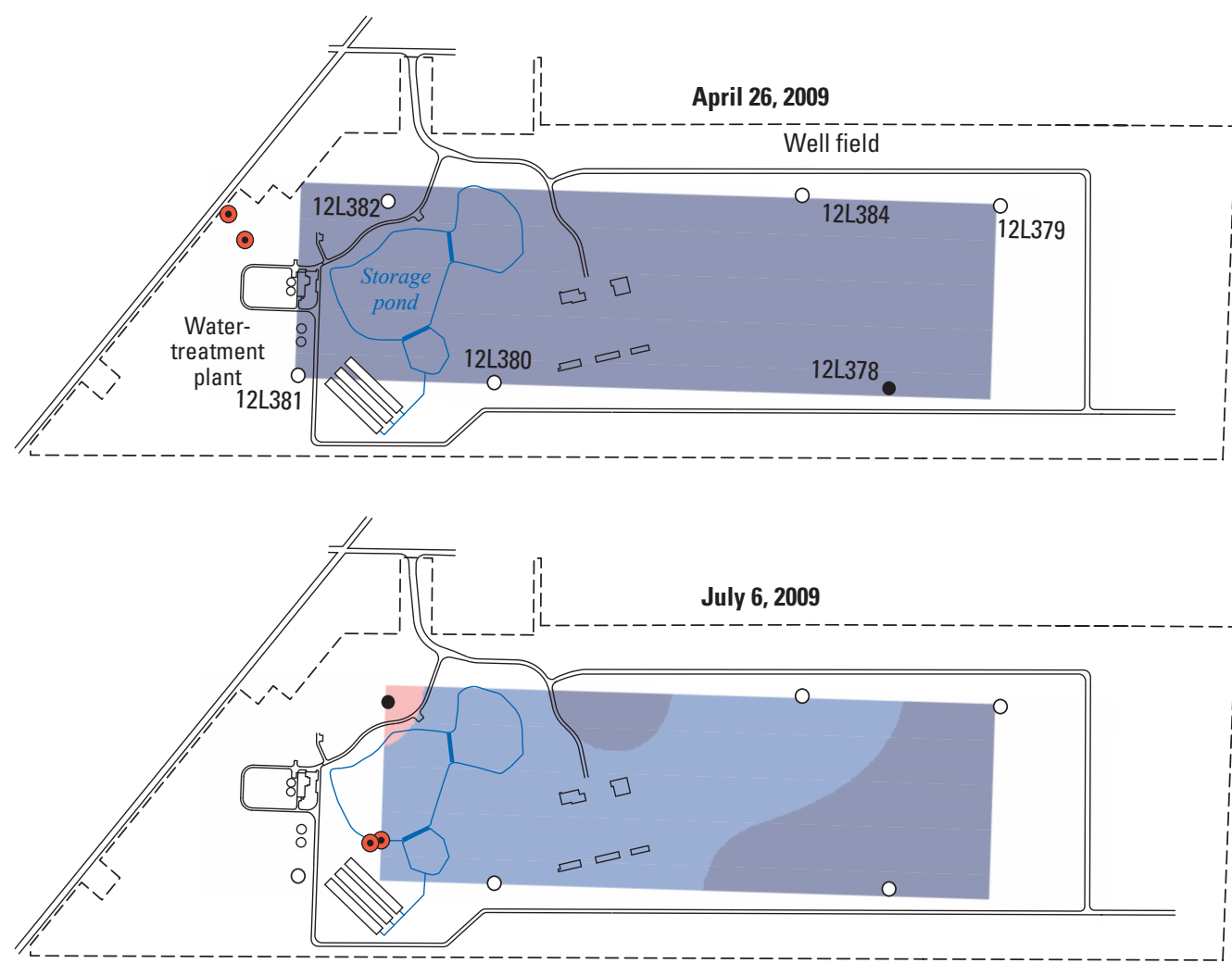

\section{EXPLANATION}

Water level, in feet, above or below top of Upper Floridan aquiferTop of Upper Floridan aquifer is indicated as zero

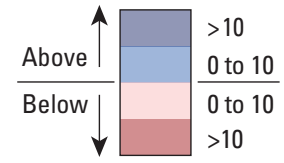

Production well O Not pumping $\bullet$ Pumping

- Sinkhole
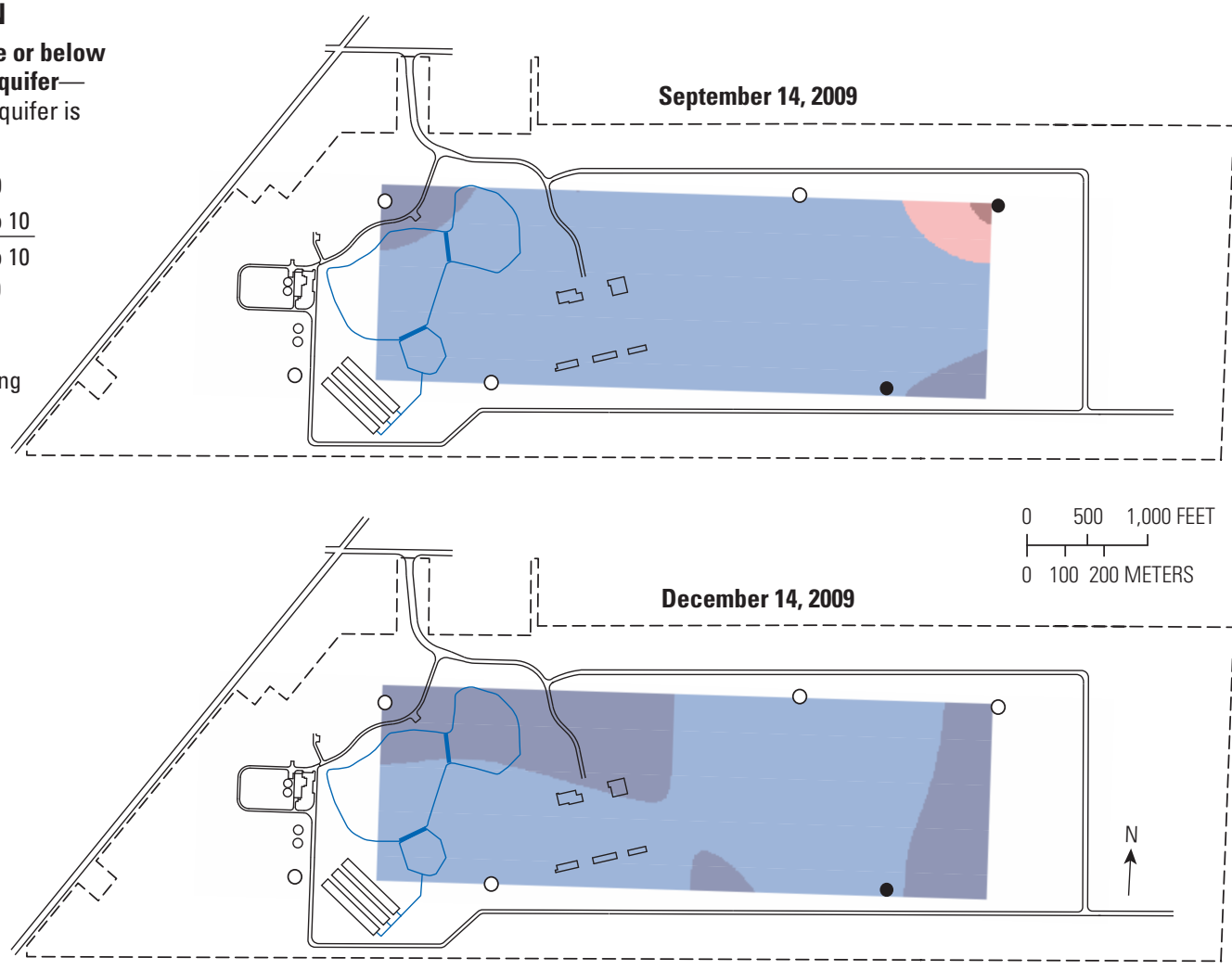

Figure 15. Potentiometric surface of the Upper Floridan aquifer relative to the top of the Upper Floridan aquifer for selected periods at the Albany well field, February 5, 2007, through December 14, 2009.-Continued 


\section{Summary}

Groundwater levels were monitored in five aquifers in the Albany, Georgia, area during 2009. In the surficial aquifer, water levels showed a sharp increase in March and April in response to heavy precipitation that exceeded 15 inches between March 28 and April 13, 2009. In the Upper Floridan aquifer, the overall water-level trend for the period of record (period of record ranged between 1957-2009 and 2003-2009) shows little change, with water levels decreasing slightly in 10 wells and increasing slightly in 4 wells. Water levels in the Claiborne aquifer increased in two wells and decreased in one well during the period of record. Water levels in the Clayton aquifer increased in two wells and decreased in four wells during the period of record. In some areas, water levels in the Clayton aquifer appear to have stabilized since the 1980s. In the Providence aquifer, water levels showed little long-term trend during the period of record (since 1978). Following more than a 2-year precipitation deficit during 2006-2007 and the first half of 2008, precipitation was normal to abovenormal during 2009. Subsequently, the stage at the Flint River at Albany streamgage (station 02352500) and Chickasawhatchee Creek streamgage (station 02354410) were above normal or close to normal during 2009. Two major rainfall events-11 inches during March 27 to April 3, 2009, and 7 inches during December 12-18, 2009-caused local streams to rise above flood stage. Groundwater levels in the Upper Floridan aquifer also rose in response to the rainfall events and stage increases in local streams.

Groundwater withdrawals, excluding irrigation, decreased by 3.3 million gallons per day (Mgal/d) from 2008 to 2009. Irrigation pumping in Dougherty County increased from about $10.9 \mathrm{Mgal} / \mathrm{d}$ in 1995 to $20.3 \mathrm{Mgal} / \mathrm{d}$ in 2000, and then decreased to about $10 \mathrm{Mgal} / \mathrm{d}$ in 2005 . The increase in irrigation pumping reflects the drought conditions in 2000 , and the decrease reflects normal precipitation for 2005.

Groundwater samples collected from 12 wells in the Upper Floridan aquifer and 1 well in the surficial aquifer indicate that concentrations of nitrate plus nitrite as nitrogen during 2009 increased slightly, with concentrations exceeding the 10-milligram-per-liter maximum contamination level in 2 wells. Water samples collected from the Flint River and wells in and around the Albany Water, Gas, and Light Commission (WGL) well field indicate that chemical constituents (major cations and anions) in groundwater from the WGL well field remain distinctly different from those in the water of the
Flint River; thus, groundwater from the well field appears not to be mixing with water from the Flint River. Water was also collected during 2008 from two municipal wells located in northern Albany and downgradient from a hazardous waste site. Analysis indicated low-level concentrations of pesticides in one of the wells; however, no pesticides were detected when the same wells were sampled during 2009.

Six new sinkholes formed at the WGL well field in 2009. Detailed geologic cross sections of the WGL well field reveal two zones of high permeability within the Upper Floridan aquifer ranging from 26 to 66 feet (ft) above NGVD 29 (125-170 ft below land surface) and from 71 to $106 \mathrm{ft}$ above NGVD 29 (106-114 ft below land surface). Because increased frequency of water-level fluctuations about the top of the Upper Floridan aquifer seems to relate to sinkhole formation, it may be possible to reduce the number of new sinkholes by controlling groundwater-level fluctuations. Ongoing groundwater-level monitoring, together with the addition of pond stage data may provide further insight into the relation between sinkhole development and water levels.

\section{References Cited}

Barber, N.L., and Stamey, T.C., 2000, Droughts in Georgia: U.S. Geological Survey Open-File Report 00-380, 2 p.

Clark, W.Z., Jr., and Zisa, A.C., 1976, Physiographic map of Georgia: Georgia Department of Natural Resources, Georgia Geologic Survey, scale 1:2,000,000.

Clarke, J.S., Faye, R.E., and Brooks, Rebekah, 1984, Hydrogeology of the Clayton aquifer of southwest Georgia: Georgia Geologic Survey Hydrologic Atlas 13, 6 pls.

Clarke, J.S., and Pierce, R.R., 1984, Georgia water factsGround-water resources in the United States, in National Water Summary, 1984: U.S. Geological Survey WaterSupply Paper 2275, p. 179-184.

Georgia Department of Natural Resources, Environmental Protection Division, 2001, Georgia's environment: Atlanta, Ga., 32 p.

Gibson, T.G., 1982, New stratigraphic unit in the Wilcox Group (upper Paleocene-lower Eocene) in Alabama and Georgia: U.S. Geological Survey Bulletin 1529-H, p. H23-32. 
Gordon, D.W., 2008, Ground-water conditions and studies in the Albany area of Dougherty County, Georgia, 2007: U.S. Geological Survey Open-File Report 2008-1328, 49 p., accessed February 8, 2011, at http://pubs.usgs.gov/ of $/ 2008 / 1328 /$.

Gordon, D.W., 2009, Groundwater conditions and studies in the Albany area of Dougherty County, Georgia, 2008: U.S. Geological Survey Open-File Report 2009-1244, 54 p. accessed February 8, 2011, at http://pubs.usgs.gov/ of/2009/1244/.

Hicks, D.W., Gill, H.E., and Longsworth, S.A., 1987, Hydrogeology, chemical quality, and availability of ground water in the Upper Floridan aquifer, Albany area, Georgia: U.S. Geological Survey Water-Resources Investigations Report 87-4145, 52 p., accessed February 8, 2011, at http://pubs.usgs.gov/wri/wri87-4145/.

Hicks, D.W., Krause, R.E., and Clarke, J.S., 1981, Geohydrology of the Albany area, Georgia: Georgia Geologic Survey Information Circular 57, 31 p.

Janert, P.K., 2010, Gnuplot in action-Understanding data with graphs: Greenwich, Conn., Manning Publications, $360 \mathrm{p}$.

Langer, W.H., 2001, Potential environmental impacts of quarrying stone in karst-A literature review: U.S. Geological Survey Open-File Report 01-0484, 34 p.

Moré, J., 1978, The Levenberg-Marquardt algorithmImplementation and theory, in Watson, G.A., ed., Numerical analysis, v. 630: Berlin, Springer-Verlag, p. 105.

National Oceanic and Atmospheric Administration, 2011, NNDC climate data online: Accessed August 11, 2011, at http://cdo.ncdc.noaa.gov/pls/plclimprod/poemain. accessrouter?datasetabbv $=S O D$.

Peck, M.F., Leeth, D.C., and Painter, J.A., 2011, Groundwater conditions and studies in Georgia, 2008-2009: U.S. Geological Survey Scientific Investigations Report 2011-5048, 83 p; available online at http://pubs.usgs.gov/sir/2011/5048/.

Peck, M.F., Painter, J.A., and Leeth, D.C., 2009, Groundwater conditions and studies in Georgia, 2006-2007:

U.S. Geological Survey Scientific Investigations Report 2009-5070, 86 p; available online at http://pubs.usgs.gov/sir/2009/5070/.
Ripy, B.J., McFadden, S.S., Perriello, P.D., and Gernazian, A.M., 1981, An interim report on the hydrogeology of the Clayton and Claiborne aquifers in southwestern Georgia: Georgia Geologic Survey Open-File Report 82-2, 66 p.

Tihansky, A.B., 1999, Sinkholes, west-central Florida, in Galloway, Devin, Jones, D.R., and Ingebritsen, S.E., eds., Land subsidence in the United States: U.S. Geological Survey Circular 1182, p. 121-140.

University of Georgia, 1991, Georgia Automated Environmental Monitoring Network, 2011, accessed August 15, 2011, at http://www.georgiaweather.net.

U.S. Environmental Protection Agency, 2000, Maximum contaminant levels (Subpart B of part 141, National Primary Drinking-Water Regulations): U.S. Code of Federal Regulations, Title 40, parts 100-149, revised as of July 1, 2000, p. 334-560.

U.S. Environmental Protection Agency, 2003, First five-year review report for T.H. Agriculture and Nutrition Operable Unit 1, Albany, Dougherty County, Georgia: Atlanta, Ga., $17 \mathrm{p}$.

U.S. Environmental Protection Agency, 2006, First five-year review report for T.H. Agriculture and Nutrition Operable Unit 2, Albany, Dougherty County, Georgia: Atlanta, Ga., $12 \mathrm{p}$.

U.S. Environmental Protection Agency, 2008, Second fiveyear review report for T.H. Agriculture and Nutrition sitewide, Albany, Dougherty County, Georgia: E² Inc., Charlottesville, Va., 60 p.

U.S. Environmental Protection Agency, 2011, Drinking water contaminants: Accessed August 4, 2011, at http://waterepa. gov/drink/contaminants/index.cfm.

Warner, Debbie, 1997, Hydrologic evaluation of the Upper Floridan aquifer in the southwestern Albany area, Georgia: U.S. Geological Survey Water-Resources Investigations Report 97-4129, 28 p.

Wilson, W.L., and Beck, B.F., 1992, Hydrogeologic factors in affecting new sinkhole development in the Orlando Area, Florida: Ground Water, v. 30, no. 6, p. 918-930. 



\section{Appendix 1. Groundwater-Level Hydrographs and Statistics for Continuously Monitored Recorder Wells and Wells Measured Periodically for $\mathbf{2 0 0 9}$ and Period of Record in the Albany Area of Dougherty County, Georgia}

For the graphs in Appendix 1:

Vertical coordinate information is referenced to the National Geodetic Vertical Datum of 1929 (NGVD 29).

Horizontal coordinate information is referenced to the North American Datum of 1983 (NAD 83).

Median daily water levels are based on a 5-year minimum period of record.

Approved data have been verified by the USGS and are considered to be final and have published status. These data are locked against any modifications or deletions.

Data displayed on these graphs may be accessed at http://waterdata.usgs.gov/ga/nwis/. 


\section{Surficial Aquifer}

Site Number: 31301908410402

Latitude: $31^{\circ} 30^{\prime} 19^{\prime \prime}$ Longitude: $84^{\circ} 10^{\prime} 46^{\prime \prime}$ Well Depth: 44.1 feet
Site Name: 12L371

Dougherty County

Datum: 191 feet
Period of Record: 2003 - 2009

Well Diameter: 2 inches
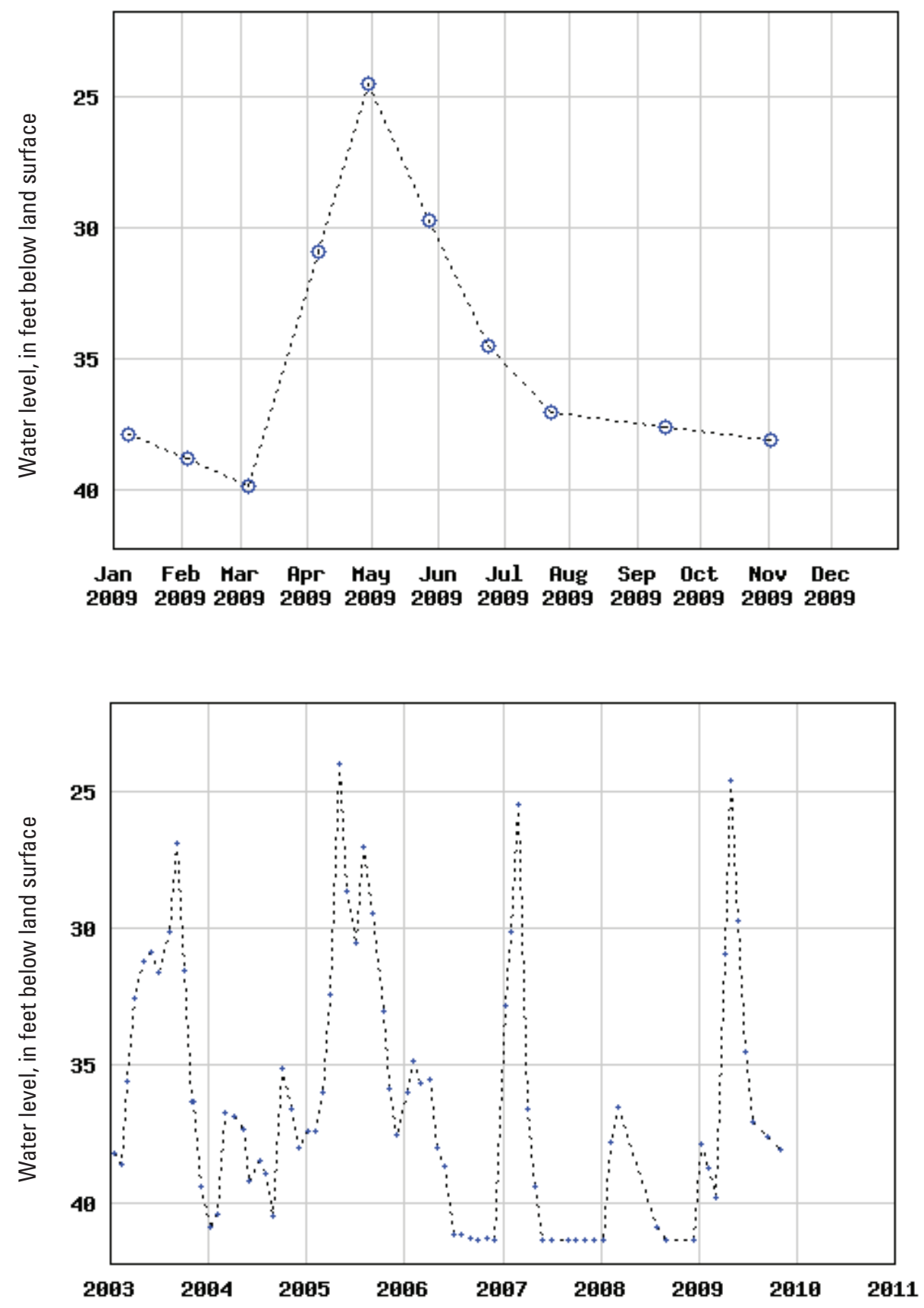

Figure 1-1. Periodic water levels in well 12L371, surficial aquifer, 2003-2009. 


\section{Surficial Aquifer}

Site Number: 313038084122501

Latitude: $31^{\circ} 30^{\prime} 42^{\prime \prime}$ Longitude: $84^{\circ} 12$ '33" Well Depth: 45 feet
Site Name: 12L376

Dougherty County

Datum: 191 feet
Period of Record: 2002 - 2009

Well Diameter: 2 inches
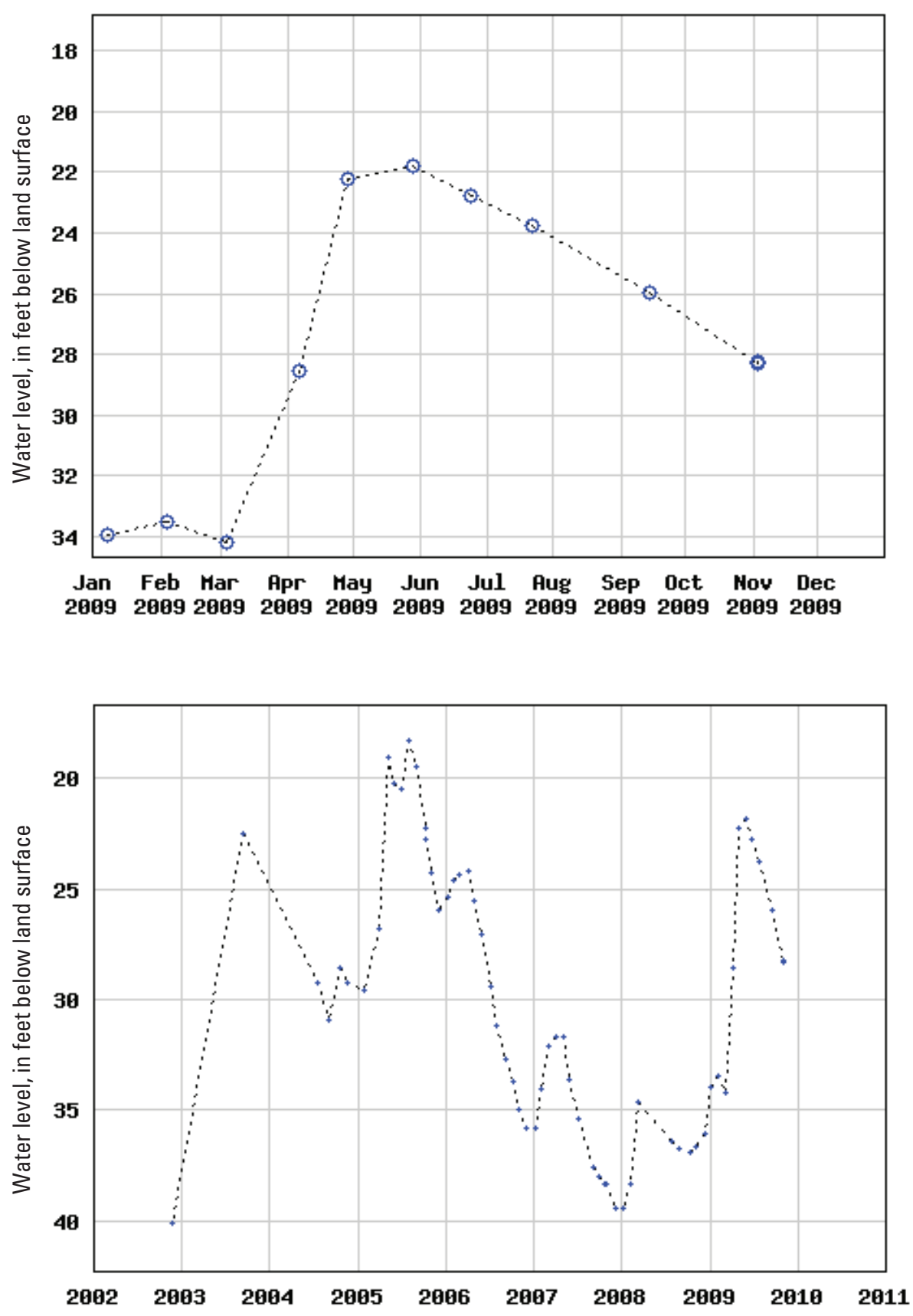

Figure 1-2. Periodic water levels in well 12L376, surficial aquifer, 2002-2009. 


\section{Upper Floridan Aquifer}

Site Number: 312919084153801

Latitude: $31^{\circ} 29^{\prime} 15^{\prime \prime}$ Longitude: $84^{\circ} 15^{\prime} 31^{\prime \prime}$ Well Depth: 150 feet
Site Name： $11 \mathrm{~K} 003$

Dougherty County

Datum: 195 feet
Period of Record: 1979 - 2009
Well Diameter: 4 inches
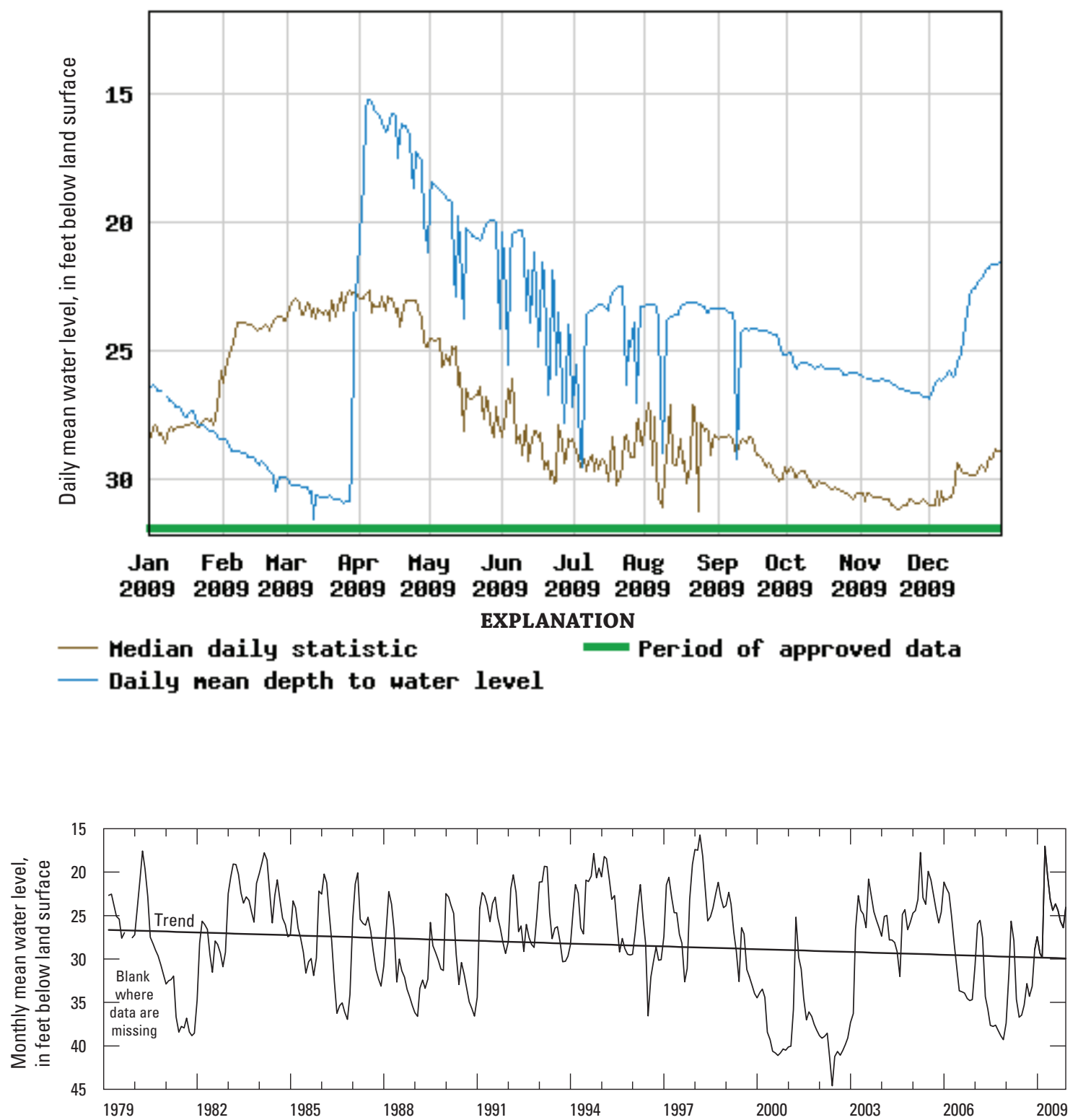

Figure 1-3. Daily and monthly mean water levels in well 11K003, Upper Floridan aquifer, 1979-2009. 


\section{Upper Floridan Aquifer}

Site Number: 312617084110701

Latitude: $31^{\circ} 26^{\prime} 12^{\prime \prime}$ Longitude: $84^{\circ} 11^{\prime} 05^{\prime \prime}$ Well Depth: 137 feet
Baker County Datum: 185 feet

\section{Site Name: 12K014}

Period of Record: 1982 - 2009

Well Diameter: 2 inches
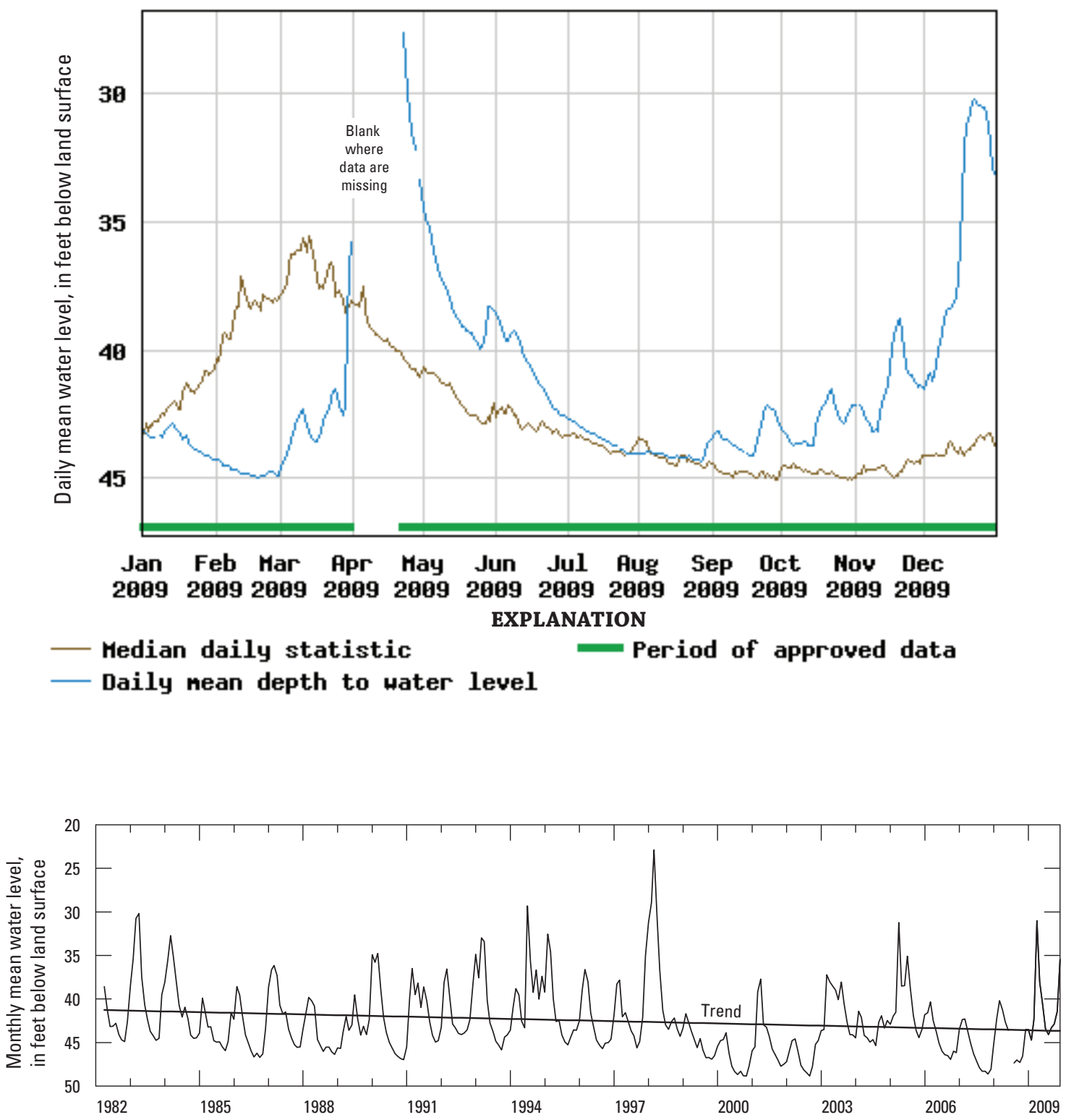

Figure 1-4. Daily and monthly mean water levels in well 12K014, Upper Floridan aquifer, 1982-2009. 


\section{Upper Floridan Aquifer}

Site Number: 312950084131801

Latitude: $31^{\circ} 29^{\prime} 51^{\prime \prime}$ Longitude: $84^{\circ} 13^{\prime} 18^{\prime \prime}$ Well Depth: 200 feet
Site Name: 12K141

Dougherty County

Datum: 195 feet
Period of Record: 1996 - 2009

Well Diameter: 4 inches
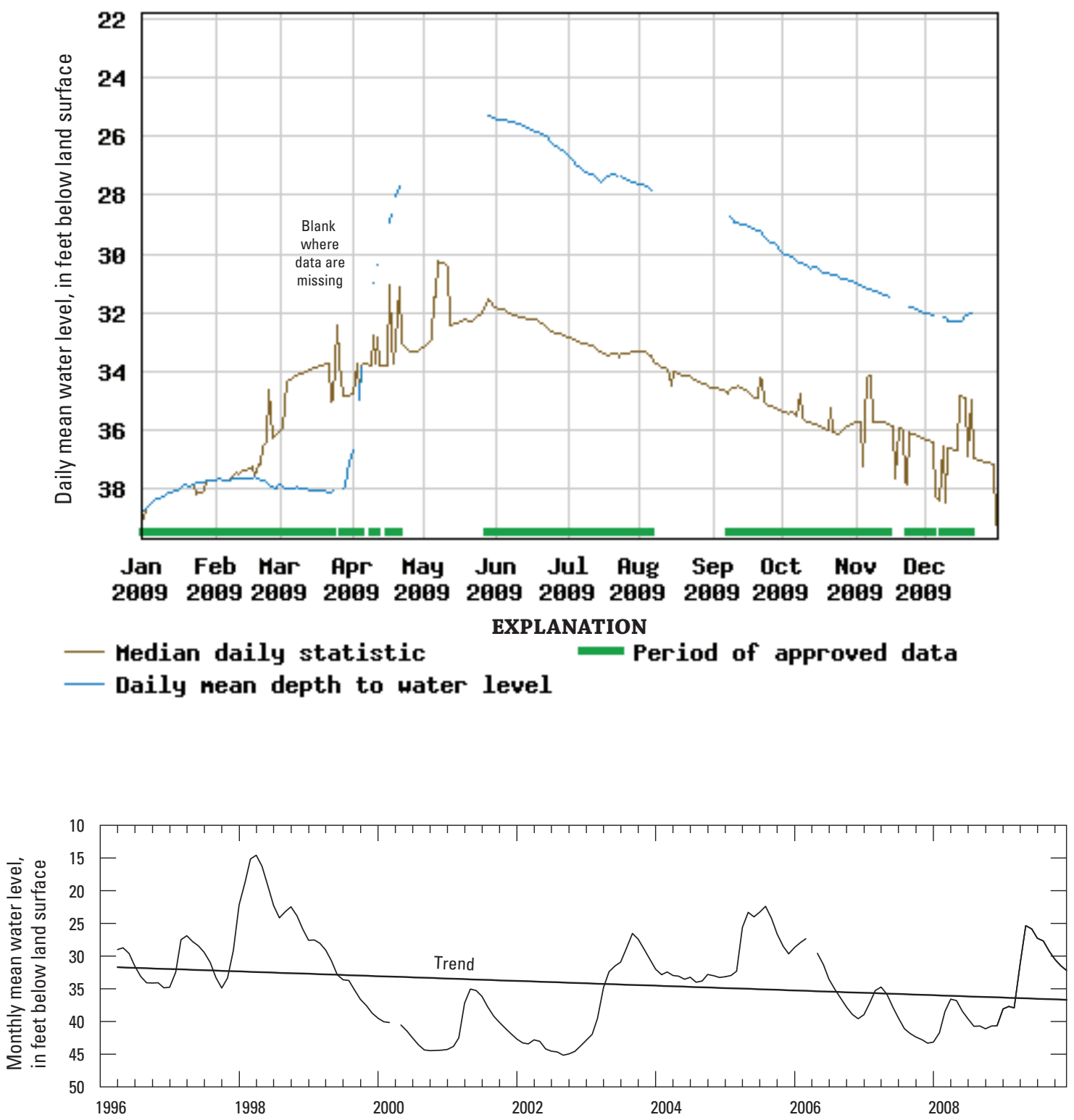

Figure 1-5. Daily and monthly mean water levels in well 12K141, Upper Floridan aquifer, 1996-2009. 


\section{Upper Floridan Aquifer}

Site Number: 312947084092201

Latitude: $31^{\circ} 29^{\prime} 46^{\prime \prime}$ Longitude: $84^{\circ} 09^{\prime} 22^{\prime \prime}$

Well Depth: 170 feet

\section{Site Name: 12K180}

Dougherty County

Datum: 172 feet
Period of Record: 2002-2009

Well Diameter: 4 inches
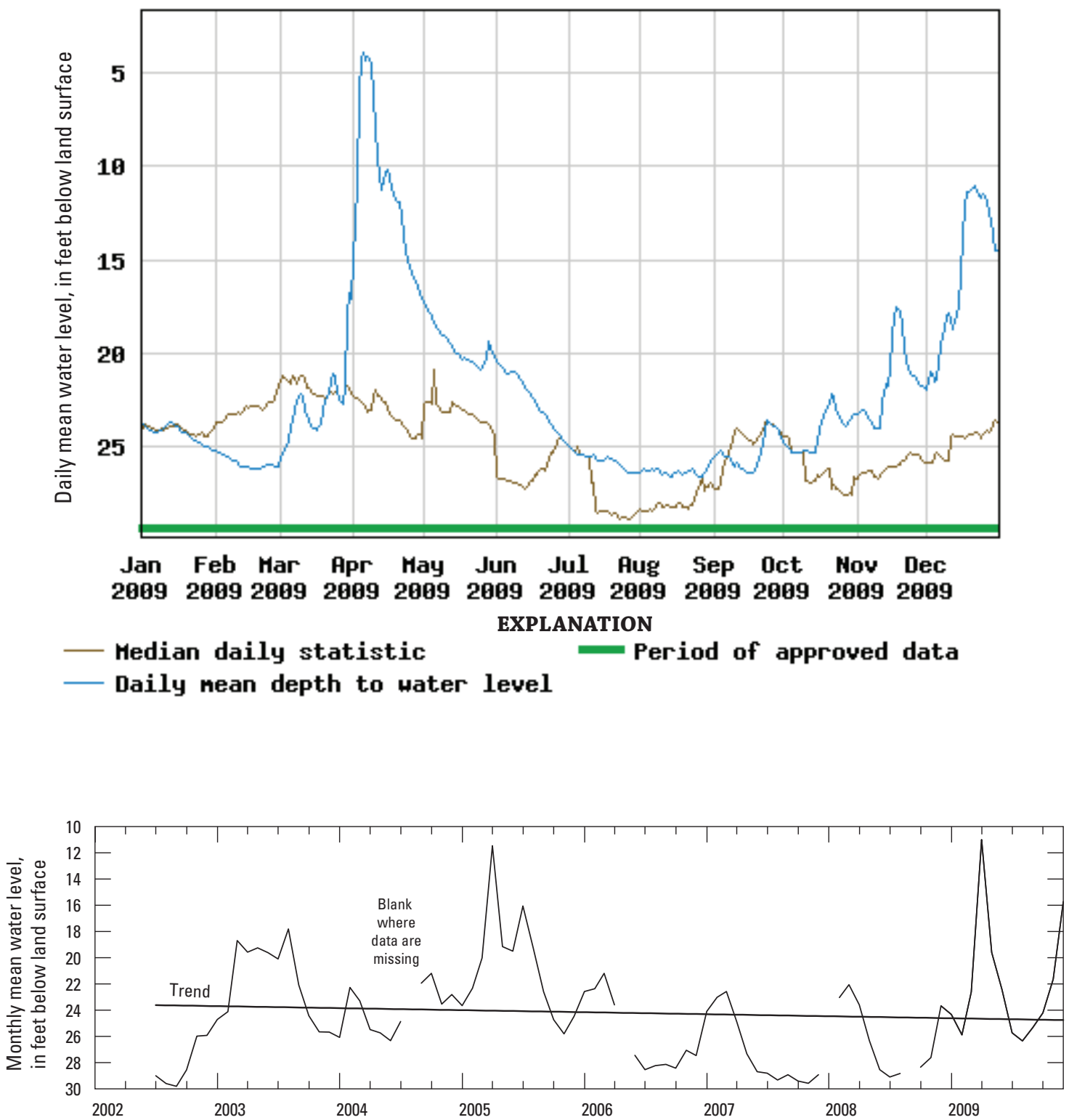

Figure 1-6. Daily and monthly mean water levels in well 12K180, Upper Floridan aquifer, 2002-2009. 


\section{Upper Floridan Aquifer}

\section{Site Number: 313450084091801}

Latitude: $31^{\circ} 34^{\prime} 51^{\prime \prime}$ Longitude: $84^{\circ} 09^{\prime} 18^{\prime \prime}$

Well Depth: 178 feet
Dougherty County

Datum: 198 feet
Site Name: $12 \mathrm{L029}$

Period of Record: 1982 - 2009

Well Diameter: 6 inches
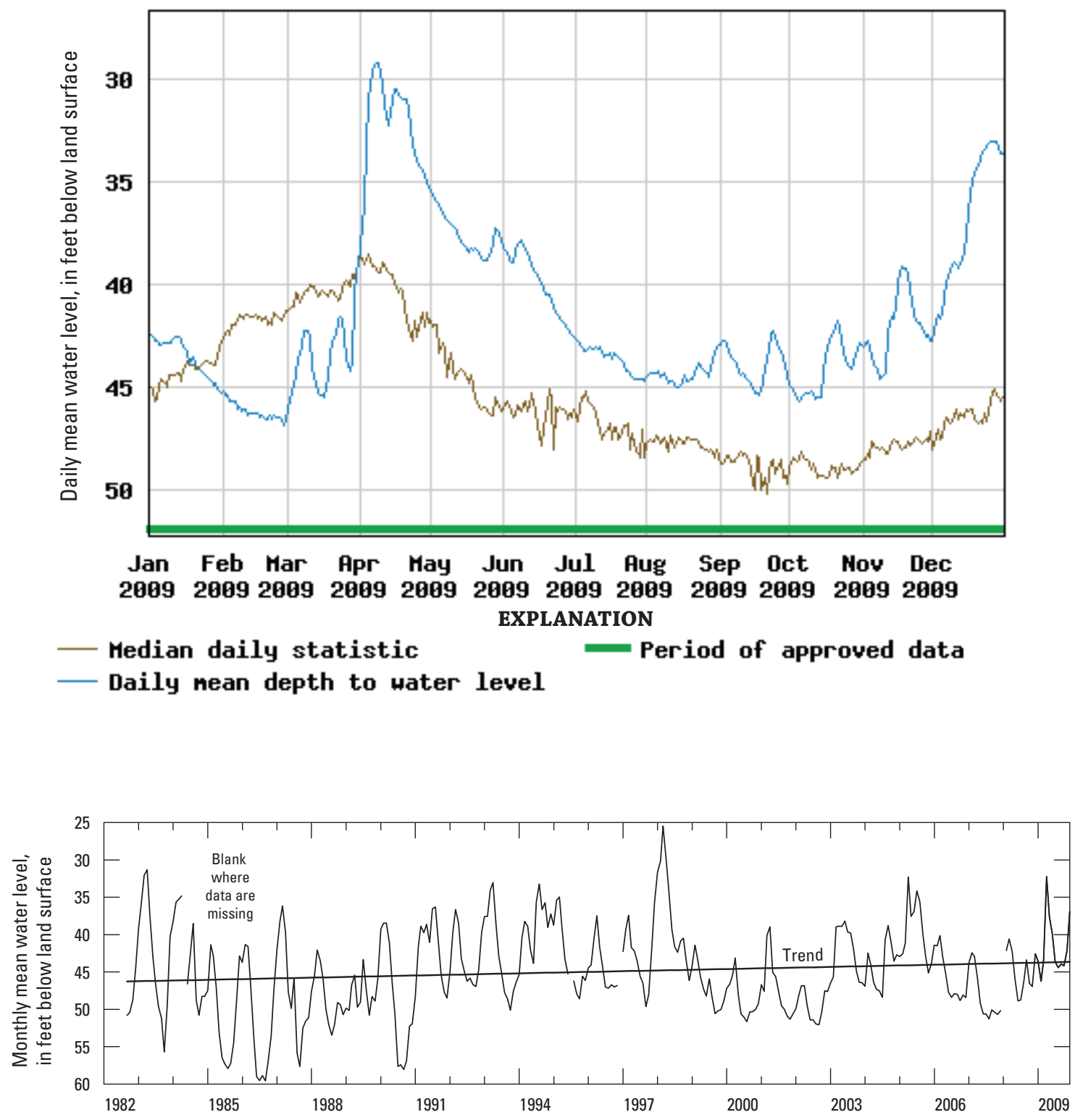

Figure 1-7. Daily and monthly mean water levels in well 12L029, Upper Floridan aquifer, 1982-2009. 


\section{Upper Floridan Aquifer}

Site Number: 313130084101001

Latitude: $31^{\circ} 31^{\prime} 31^{\prime \prime}$ Longitude: $84^{\circ} 10^{\prime} 10^{\prime \prime}$ Well Depth: 180 feet

\section{Site Name: 12L030}

Dougherty County

Datum: 179 feet
Period of Record: 1985 - 2009

Well Diameter: 4 inches
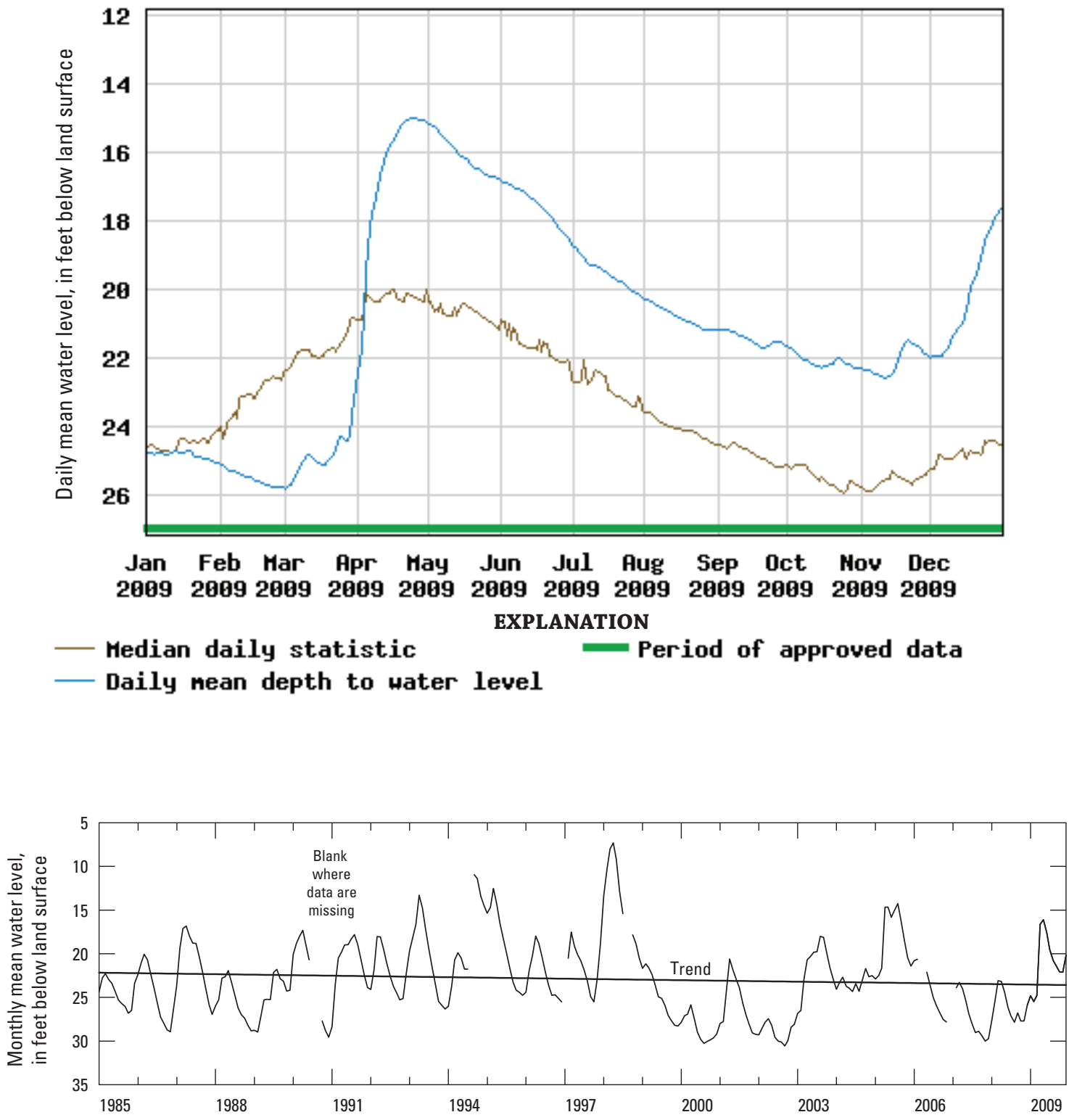

Figure 1-8. Daily and monthly mean water levels in well 12L030, Upper Floridan aquifer, 1985-2009. 


\section{Upper Floridan Aquifer}

Site Number: 313040084125901

Latitude: $31^{\circ} 30^{\prime} 41^{\prime \prime}$ Longitude: $84^{\circ} 12^{\prime} 59^{\prime \prime}$ Well Depth: 203 feet
Dougherty County

Datum: 185 feet
Site Name: 12L277

Period of Record: 1998 - 2009

Well Diameter: 4 inches
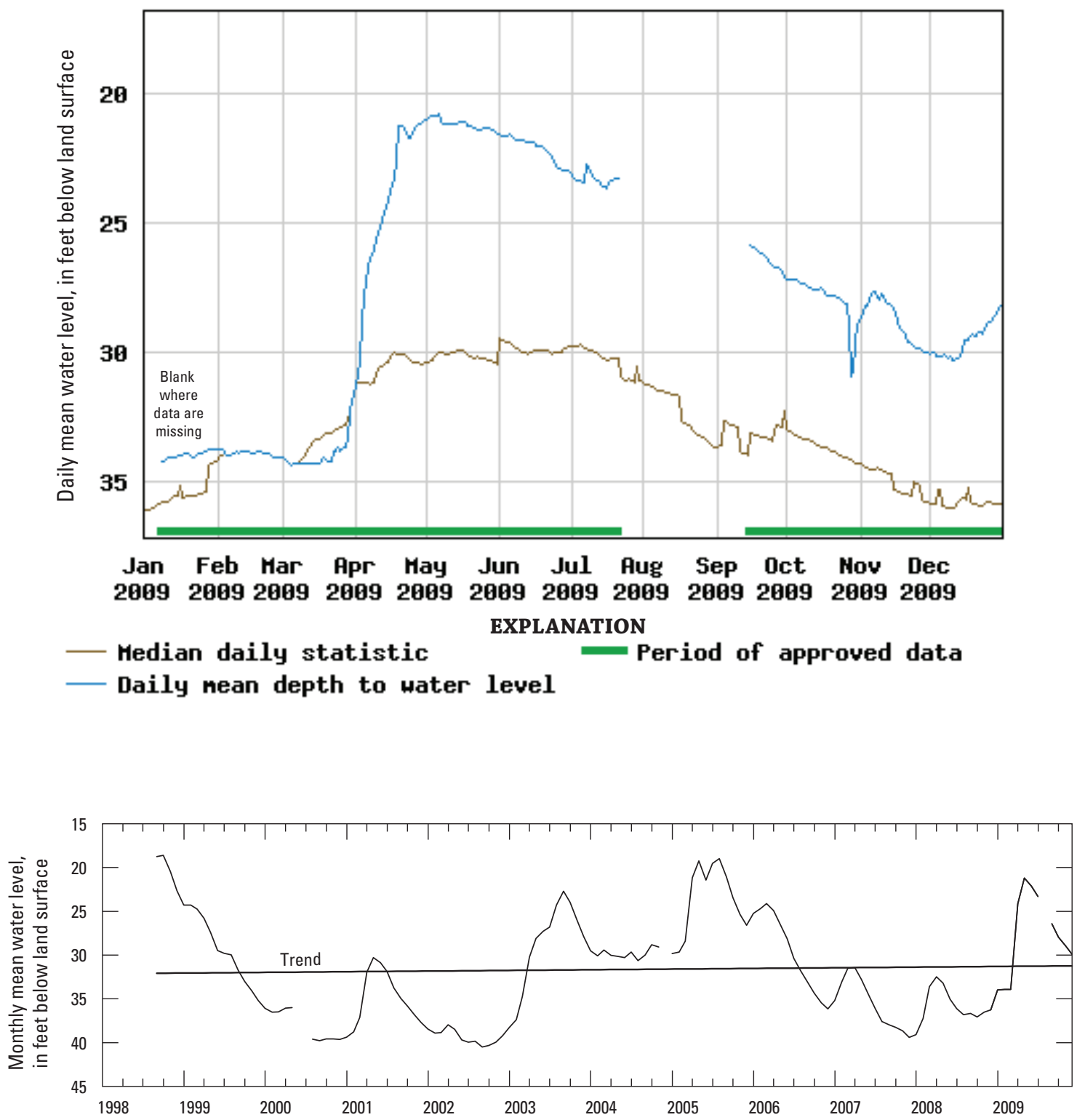

Figure 1-9. Daily and monthly mean water levels in well 12L277, Upper Floridan aquifer, 1998-2009. 


\section{Upper Floridan Aquifer}

Site Number: 313019084104601

Latitude: $31^{\circ} 30^{\prime} 20^{\prime \prime}$ Longitude: $84^{\circ} 10^{\prime} 46^{\prime \prime}$

Well Depth: 172 feet
Dougherty County

Datum: 190 feet
Site Name: 12L370

Period of Re cord: 2000 - 2009

Well Diameter: 6 inches
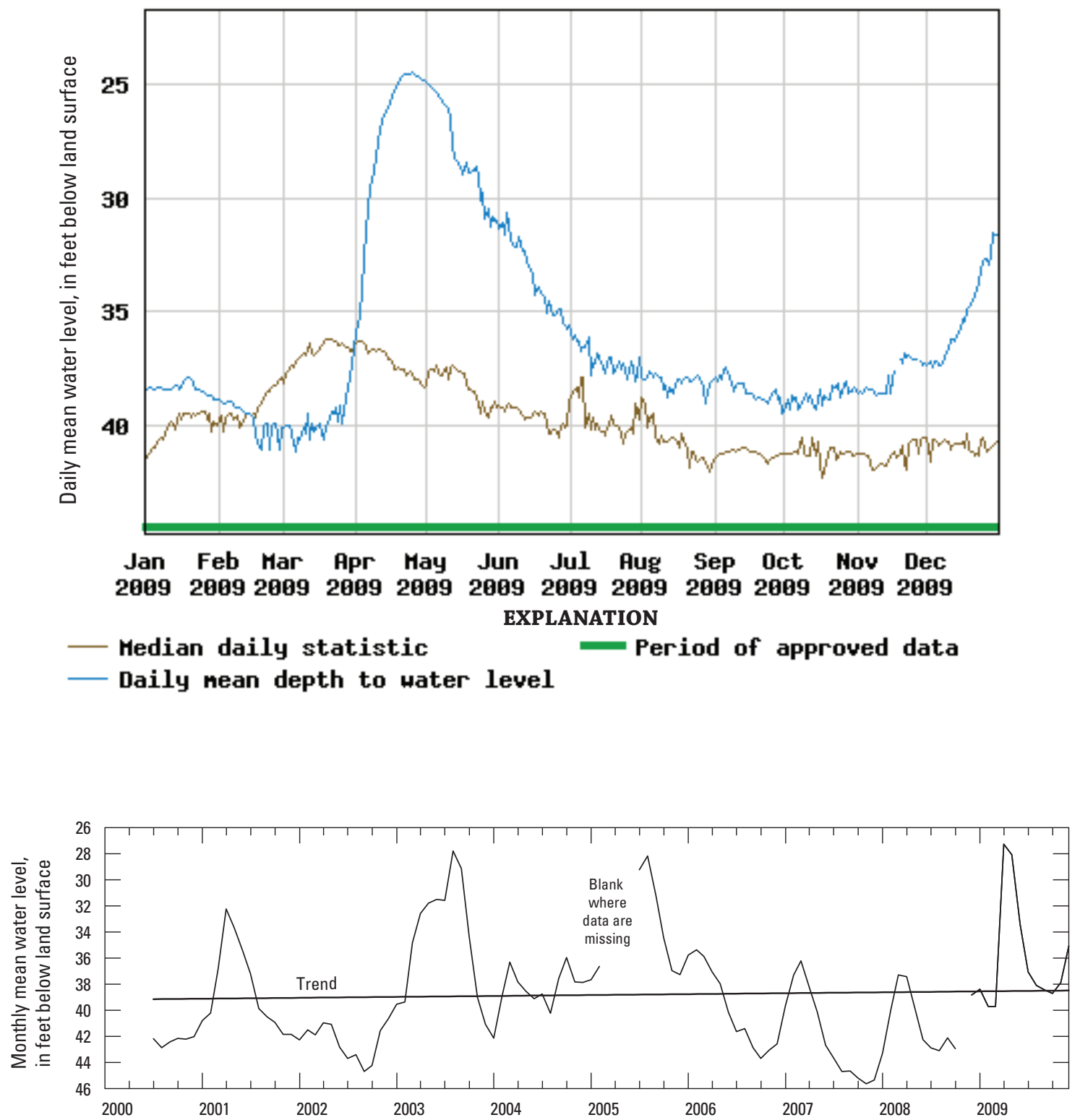

Figure 1-10. Daily and monthly mean water levels in well 12L370, Upper Floridan aquifer, 2000-2009. 


\section{Upper Floridan Aquifer}

Site Number: 313019084104603

Latitude: $31^{\circ} 30^{\prime} 19^{\prime \prime}$ Longitude: $84^{\circ} 1046^{\prime \prime}$ Well Depth: 58 feet
Dougherty County

Datum: 188 feet
Site Name: 12L372

Period of Record: 2000 - 2009

Well Diameter: 2 inches
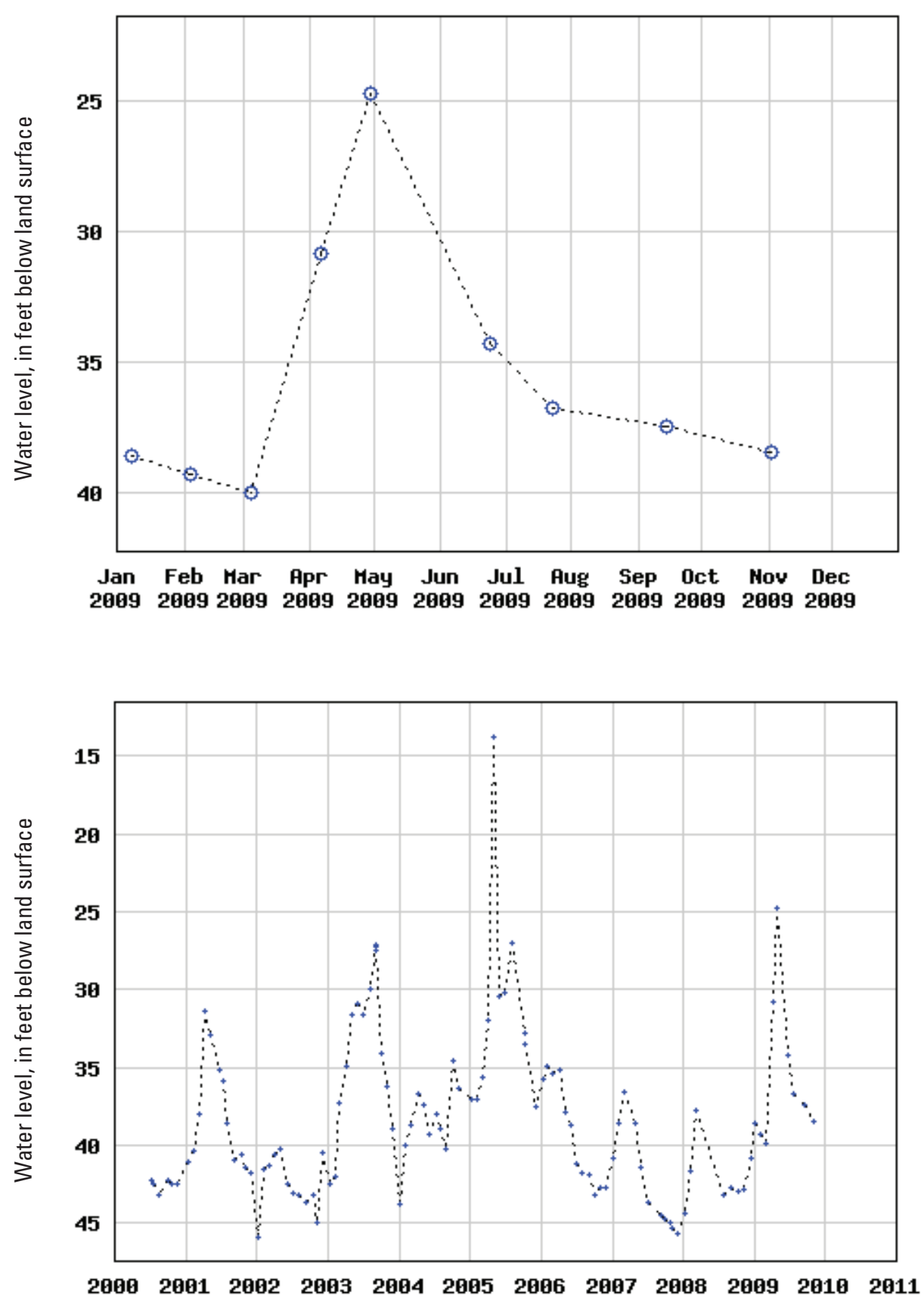

Figure 1-11. Periodic water levels in well 12L372, Upper Floridan aquifer, 2000-2009. 


\section{Upper Floridan Aquifer}

Site Number: 313000084100301

Latitude: $31^{\circ} 30^{\prime} 00^{\prime \prime}$ Longitude: $84^{\circ} 10^{\prime} 02^{\prime \prime}$

Well Depth: 170 feet
Site Name: 12L373

Dougherty County

Datum: 186 feet
Period of Record: 2002 - 2009

Well Diameter: 4 inches
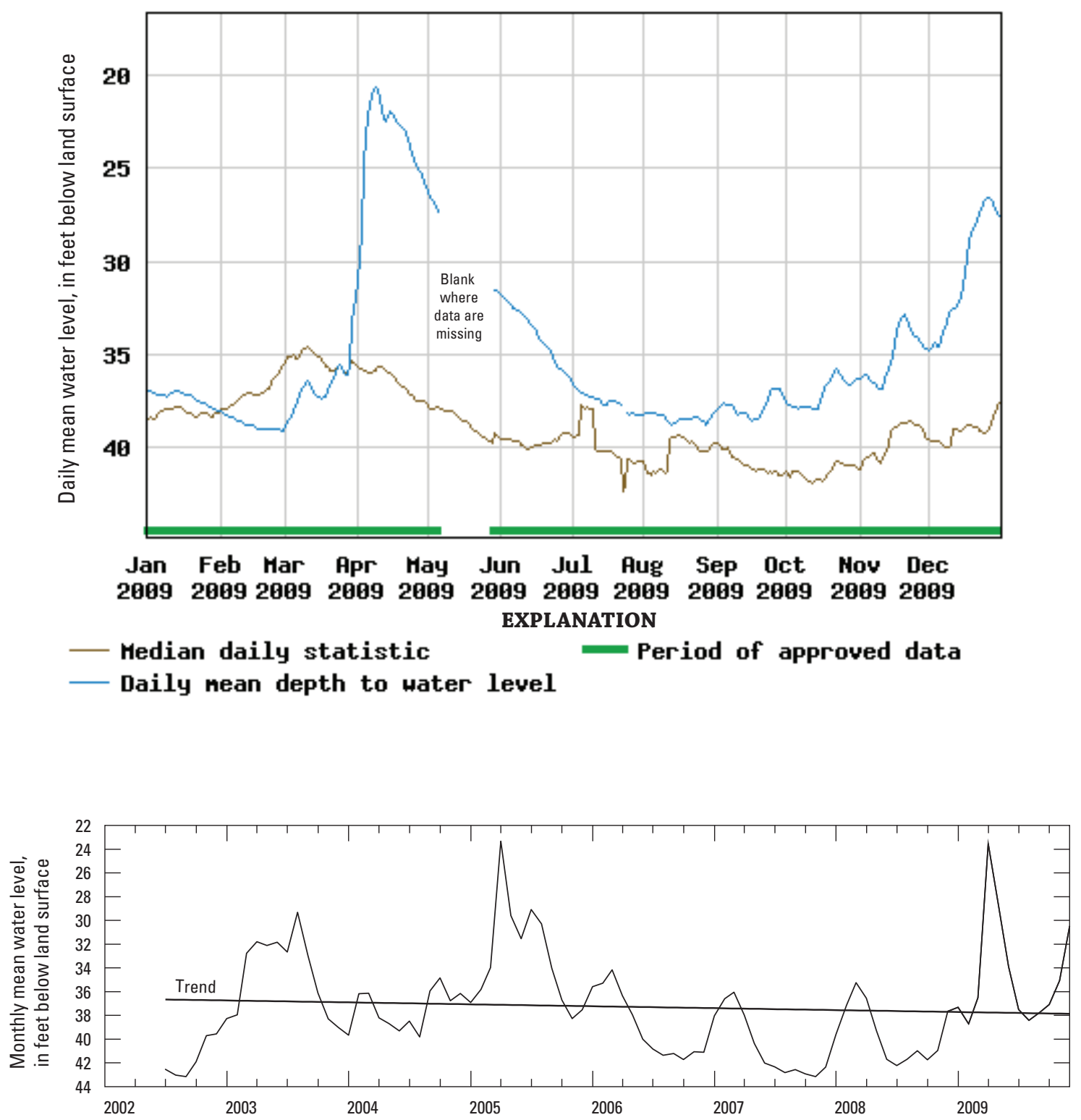

Figure 1-12. Daily and monthly mean water levels in well 12L373, Upper Floridan aquifer, 2002-2009. 


\section{Upper Floridan Aquifer}

Site Number: 313808084093601

Latitude: $31^{\circ} 38^{\prime} 09^{\prime \prime}$ Longitude: $84^{\circ} 09^{\prime} 36^{\prime \prime}$

Well Depth: 181 feet
Site Name: 12M017
Lee County

Datum: 225 feet
Period of Record: $1982-2009$

Well Diameter: 4 inches

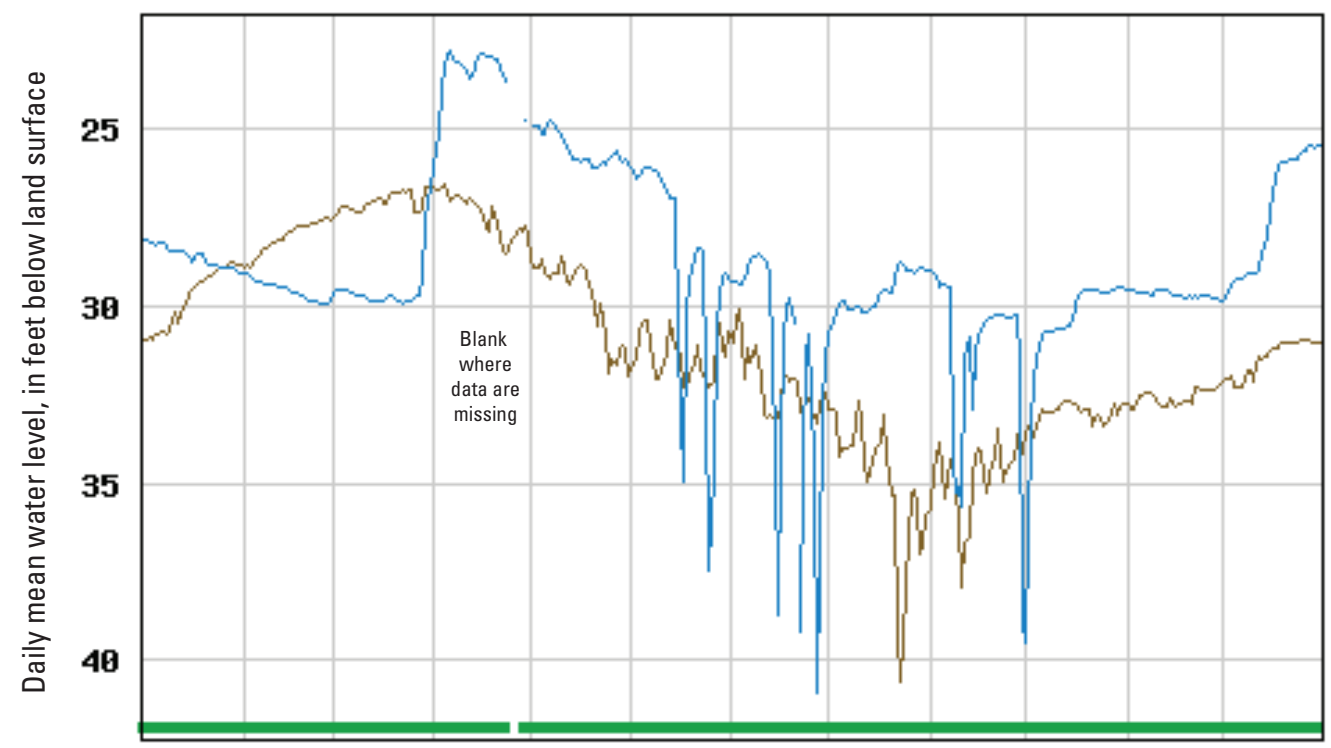

Jan Feb Har Apr Hay Jun Jul Aug Sep Oct Hov Dec 200920092009200920092009200920092009200920092009

- Median daily statistic EXPLANATION Daily nean depth to water level

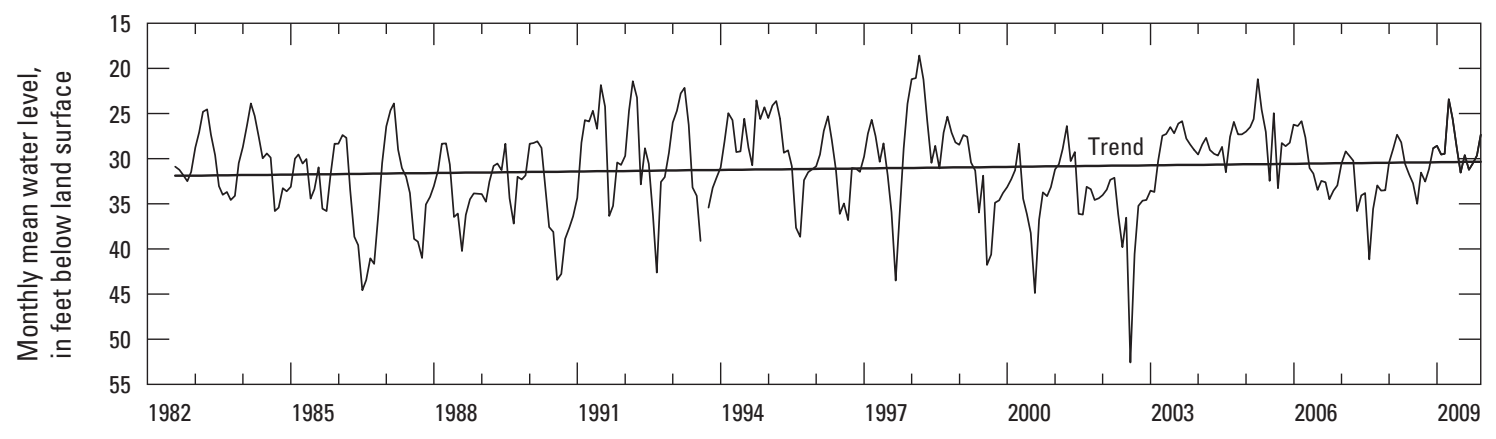

Figure 1-13. Daily and monthly mean water levels in well 12M017, Upper Floridan aquifer, 1982-2009. 


\section{Upper Floridan Aquifer}

Site Number: 312704084071601

Latitude: $31^{\circ} 27^{\prime} 05^{\prime \prime}$ Longitude: $84^{\circ} 07^{\prime} 16^{\prime \prime}$ Well Depth: 131 feet
Site Name: $13 \mathrm{~K} 014$

Dougherty County

Datum: 180 feet
Period of Record: 1982 - 2009

Well Diameter: 4 inches
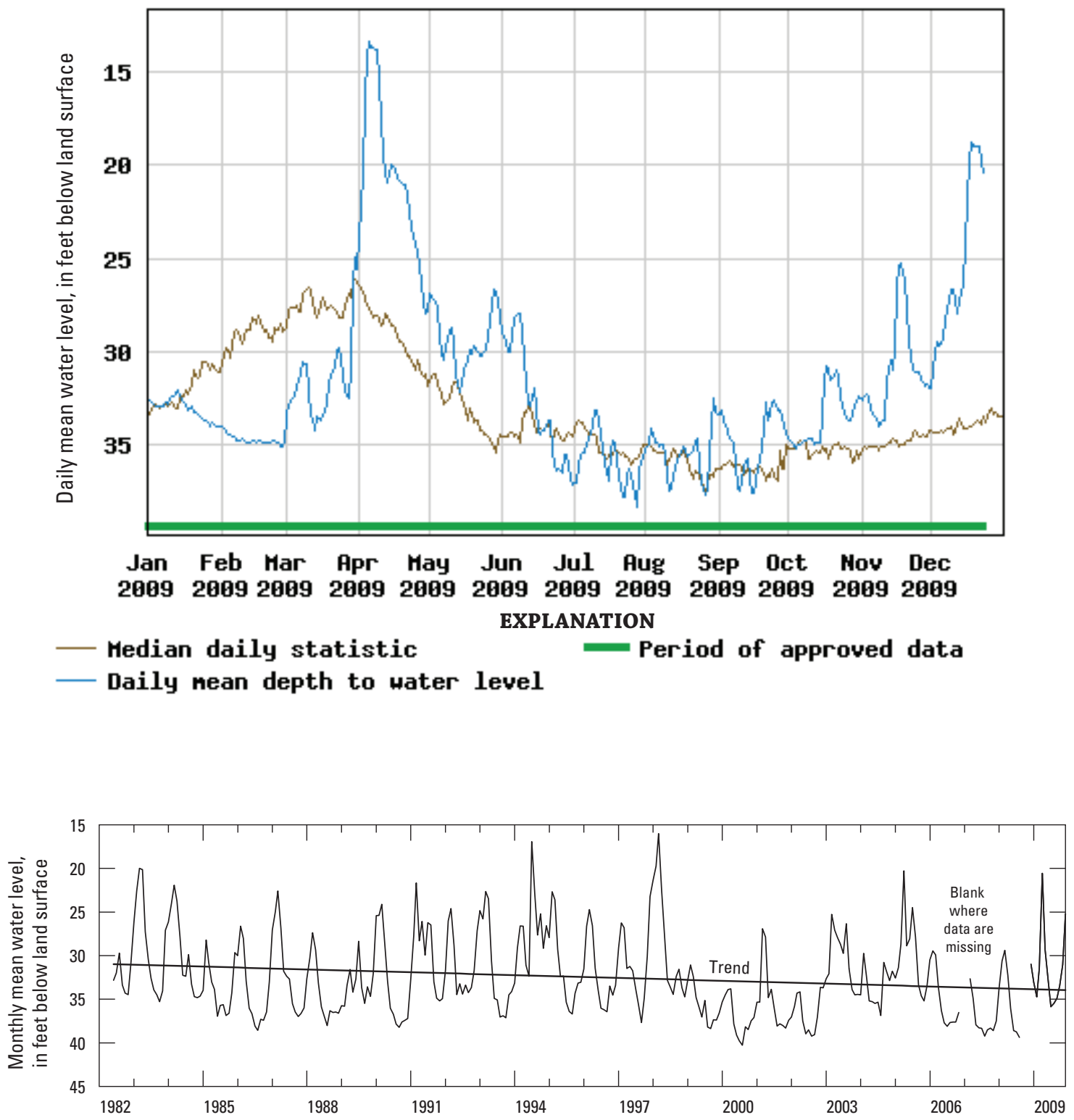

Figure 1-14. Daily and monthly mean water levels in well 13K014, Upper Floridan aquifer, 1982-2009. 


\section{Upper Floridan Aquifer}

Site Number: 313105084064302

Latitude: $31^{\circ} 31^{\prime}$ 06" Longitude: $84^{\circ} 06^{\prime} 43^{\prime \prime}$ Well Depth: 218 feet
Dougherty County Datum: 195 feet
Site Name: 13L012

Period of Record: 1977 - 2009

Well Diameter: 4 inches
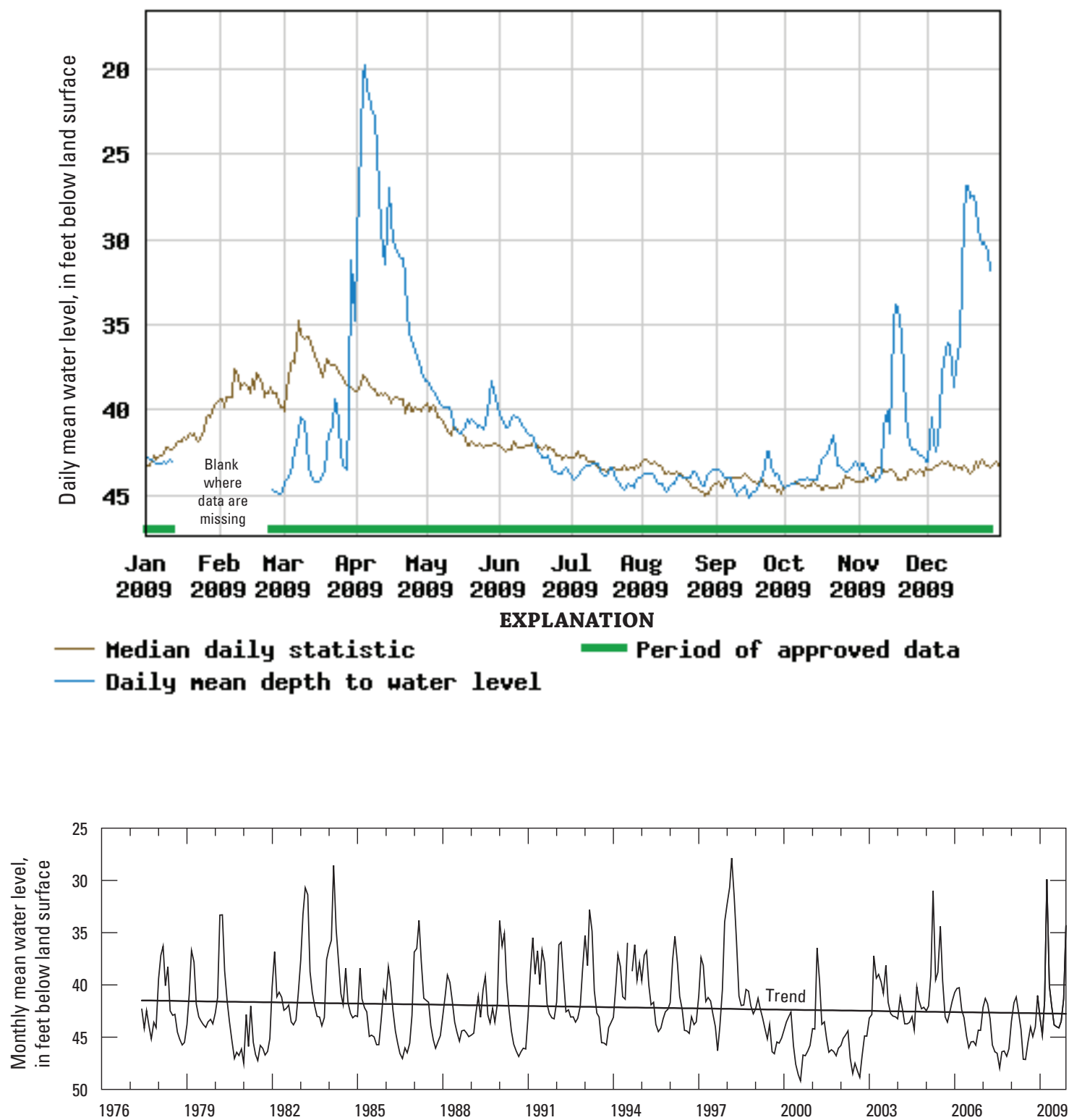

Figure 1-15. Daily and monthly mean water levels in well 13L012, Upper Floridan aquifer, 1977-2009. 


\section{Upper Floridan Aquifer}

Site Number: 313521084051001

Latitude: $31^{\circ} 35^{\prime} 22^{\prime \prime}$ Longitude: $84^{\circ} 05^{\prime} 10^{\prime \prime}$ Well Depth: 170 feet
Dougherty County

Datum: 205 feet

\section{Site Name: 13L049}

Period of Record: 1985 - 2009 Well Diameter: 6 inches

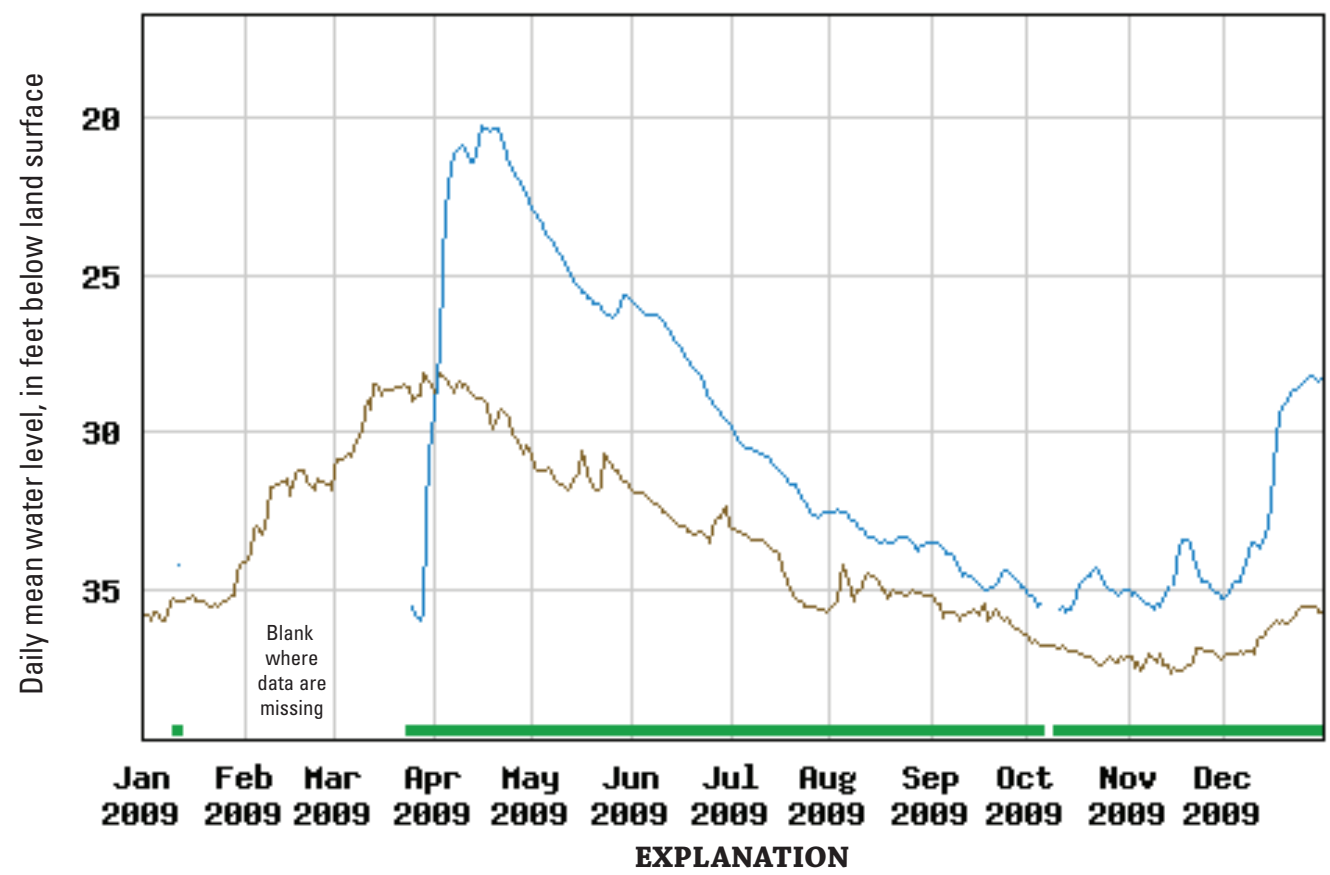

Median daily statistic Period of approved data

Daily nean depth to water level

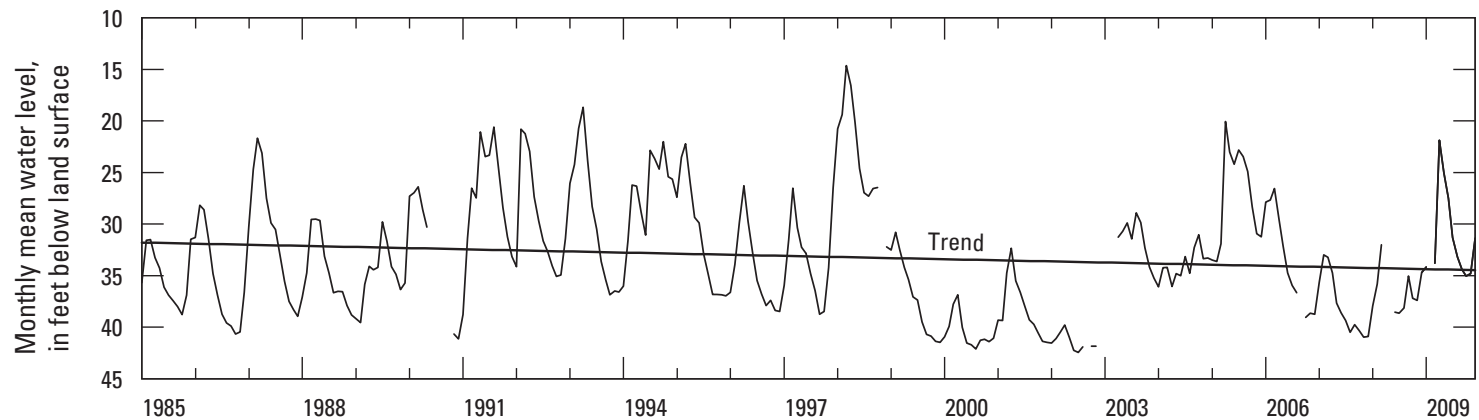

Figure 1-16. Daily and monthly mean water levels in well 13L049, Upper Floridan aquifer, 1985-2009. 


\section{Upper Floridan Aquifer}

Site Number: 313247084005001

Latitude: $31^{\circ} 32^{\prime} 48^{\prime \prime}$ Longitude: $84^{\circ} 00^{\prime} 50^{\prime \prime}$ Well Depth: 310 feet
Dougherty County

Datum: 230 feet
Site Name: 13L180

Period of Record: 1996 - 2009

Well Diameter: 4 inches
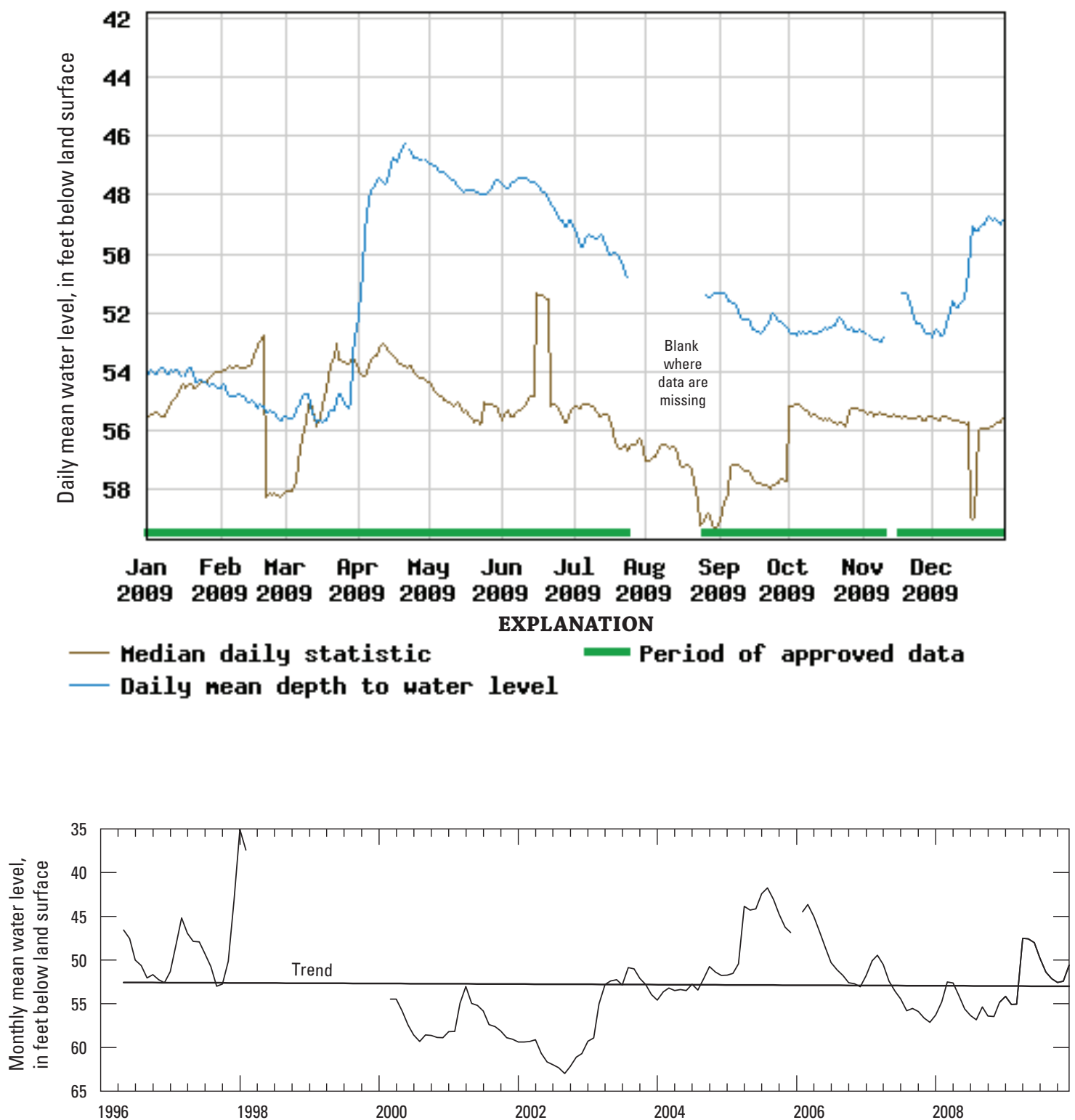

Figure 1-17. Daily and monthly mean water levels in well 13L180, Upper Floridan aquifer, 1996-2009. 


\section{Claiborne Aquifer}

Site Number: 313534084103001

Latitude: $31^{\circ} 35^{\prime} 37^{\prime \prime}$ Longitude: $84^{\circ} 10^{\prime} 30^{\prime \prime}$

Well Depth: 257 feet
Site Name: 12L019

Dougherty County

Datum: 195 feet

\author{
Period of Record: 1978 - 2009 \\ Well Diameter: 6 inches
}
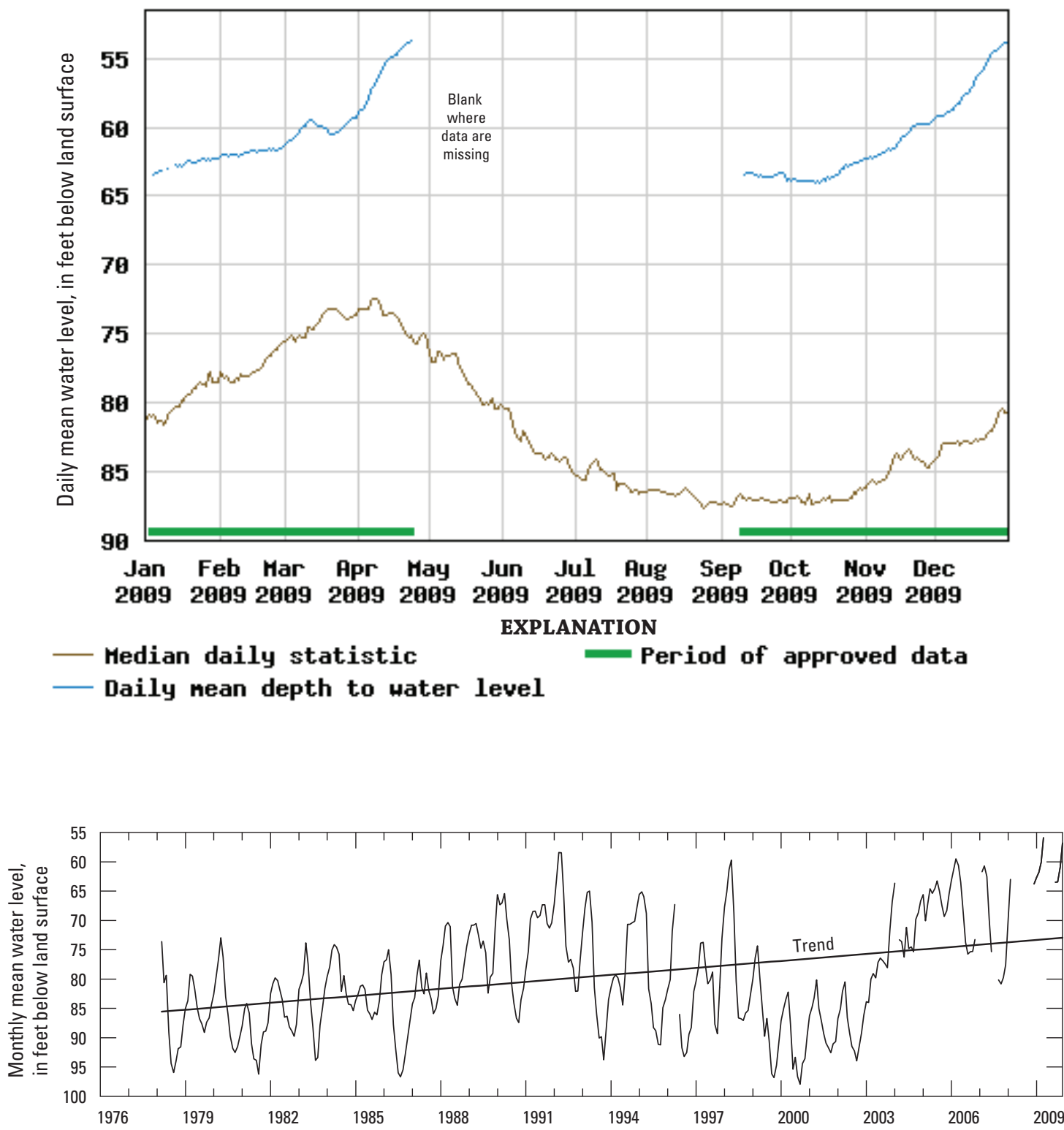

Figure 1-18. Daily and monthly mean water levels in well 12L019, Claiborne aquifer, 1978-2009. 


\section{Claiborne Aquifer}

Site Number: 313105084064301

Latitude: $31^{\circ} 31^{\prime} 06^{\prime \prime}$ Longitude: $84^{\circ} 06^{\prime} 43^{\prime \prime}$ Well Depth: 418 feet

\section{Site Name: 13L011}

Dougherty County

Datum: 195 feet
Period of Record: 1977 - 2009

Well Diameter: 4 inches
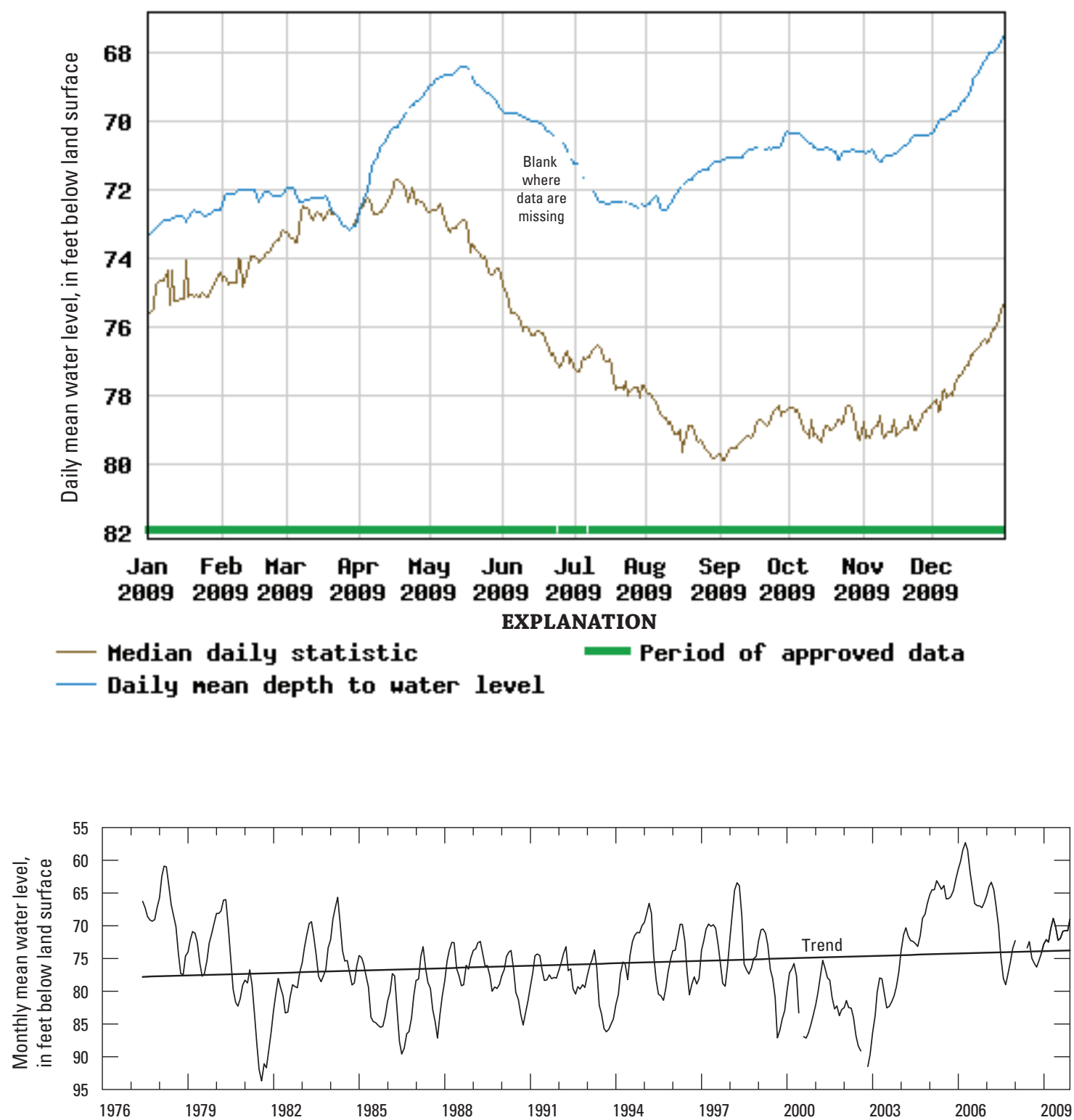

Figure 1-19. Daily and monthly mean water levels in well 13L011, Claiborne aquifer, 1977-2009. 


\section{Claiborne Aquifer}

Site Number: 313625084041501

Latitude: $31^{\circ} 36^{\prime} 22^{\prime \prime}$ Longitude: $84^{\circ} 04^{\prime} 09^{\prime \prime}$

Well Depth: 351 feet

\section{Site Name: 13L015}

Dougherty County

Datum: 200 feet
Period of Record: 1979 - 2009

Well Diameter: 4 inches
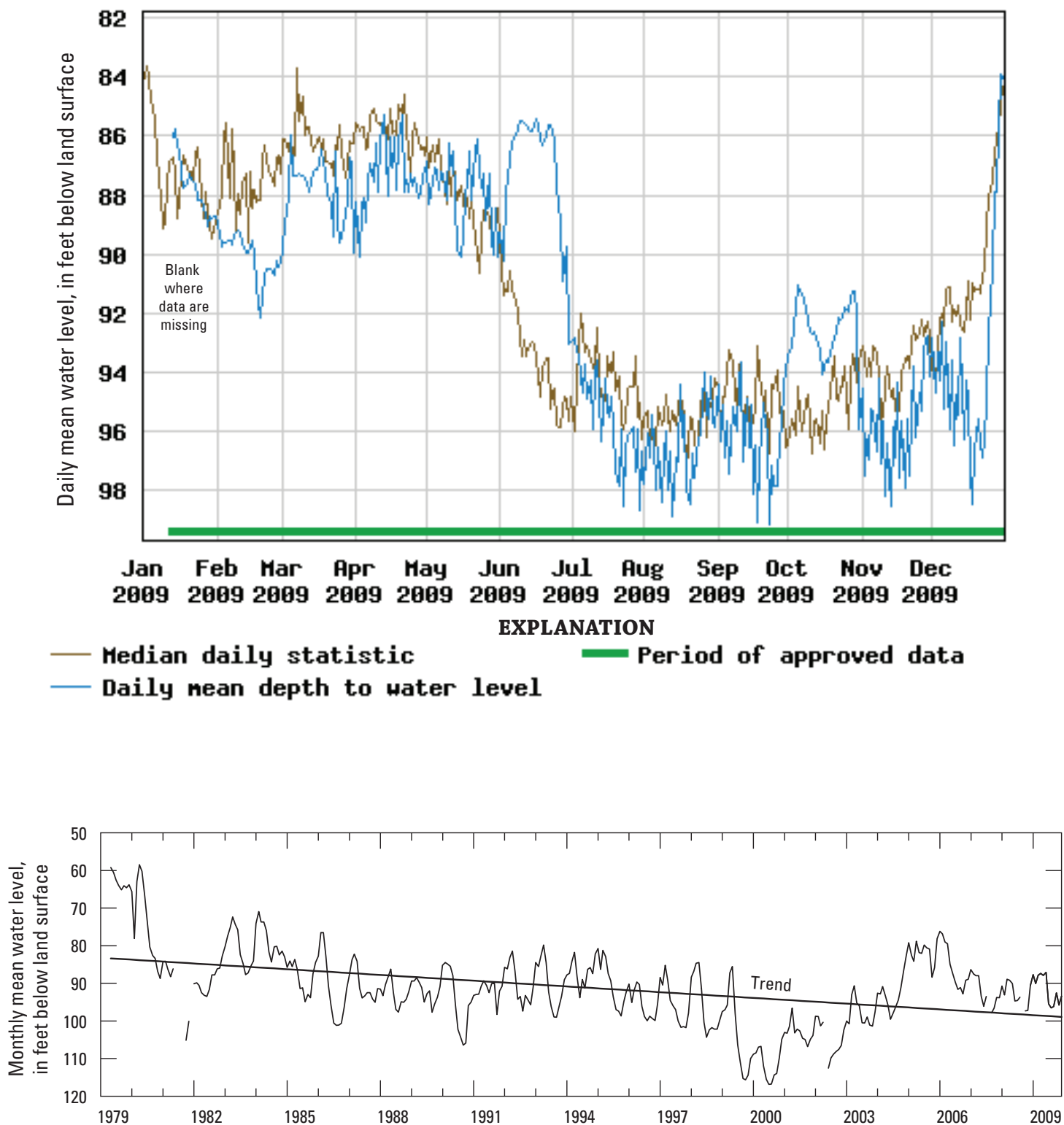

Figure 1-20. Daily and monthly mean water levels in well 13L015, Claiborne aquifer, 1979-2009. 


\section{Claiborne Aquifer}

Site Number: 312654084210102

Latitude: $31^{\circ} 26^{\prime} 54^{\prime \prime}$ Longitude: $84^{\circ} 21^{\prime} 01^{\prime \prime}$

Well Depth: 320 feet

\section{Site Name: 11 K002}

$\begin{array}{cc}\text { Dougherty County } & \text { Period of Record: } 1979-2009 \\ \text { Datum: } 183 \text { feet } & \text { Well Diameter: } 6 \text { inches }\end{array}$

Well Diameter: 6 inches
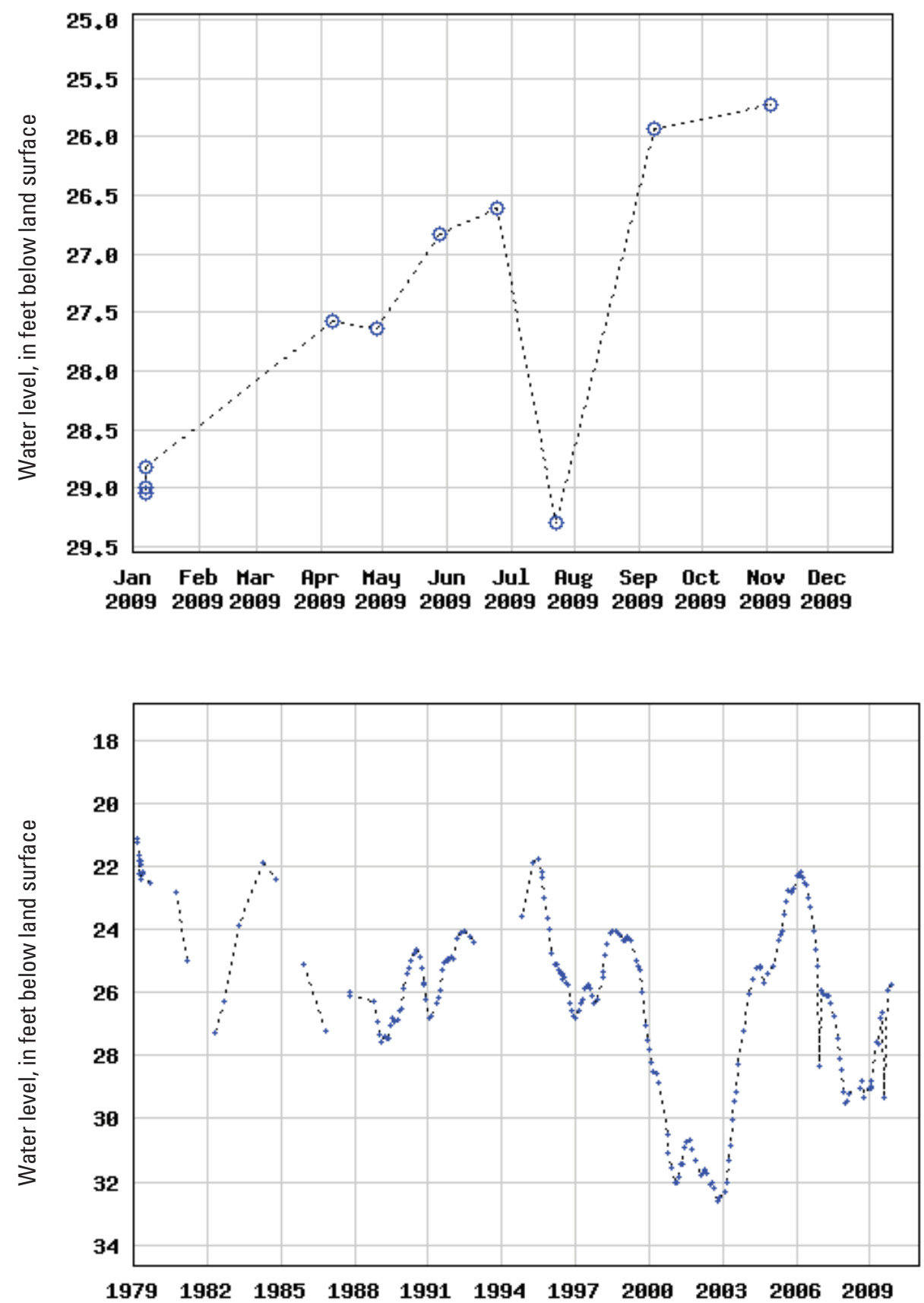

Figure 1-21. Periodic water levels in well 11K002, Claiborne aquifer, 1979-2009. 


\section{Claiborne Aquifer}

Site Number: $\quad 313530084203202$

Latitude: $31^{\circ} 35^{\prime} 30^{\prime \prime}$ Longitude: $84^{\circ} 20^{\prime} 34^{\prime \prime}$ Well Depth: 251 feet
Site Name: 11L001

Dougherty County

Datum: 220 feet
Period of Record: 1979 - 2009

Well Diameter: 4 inches
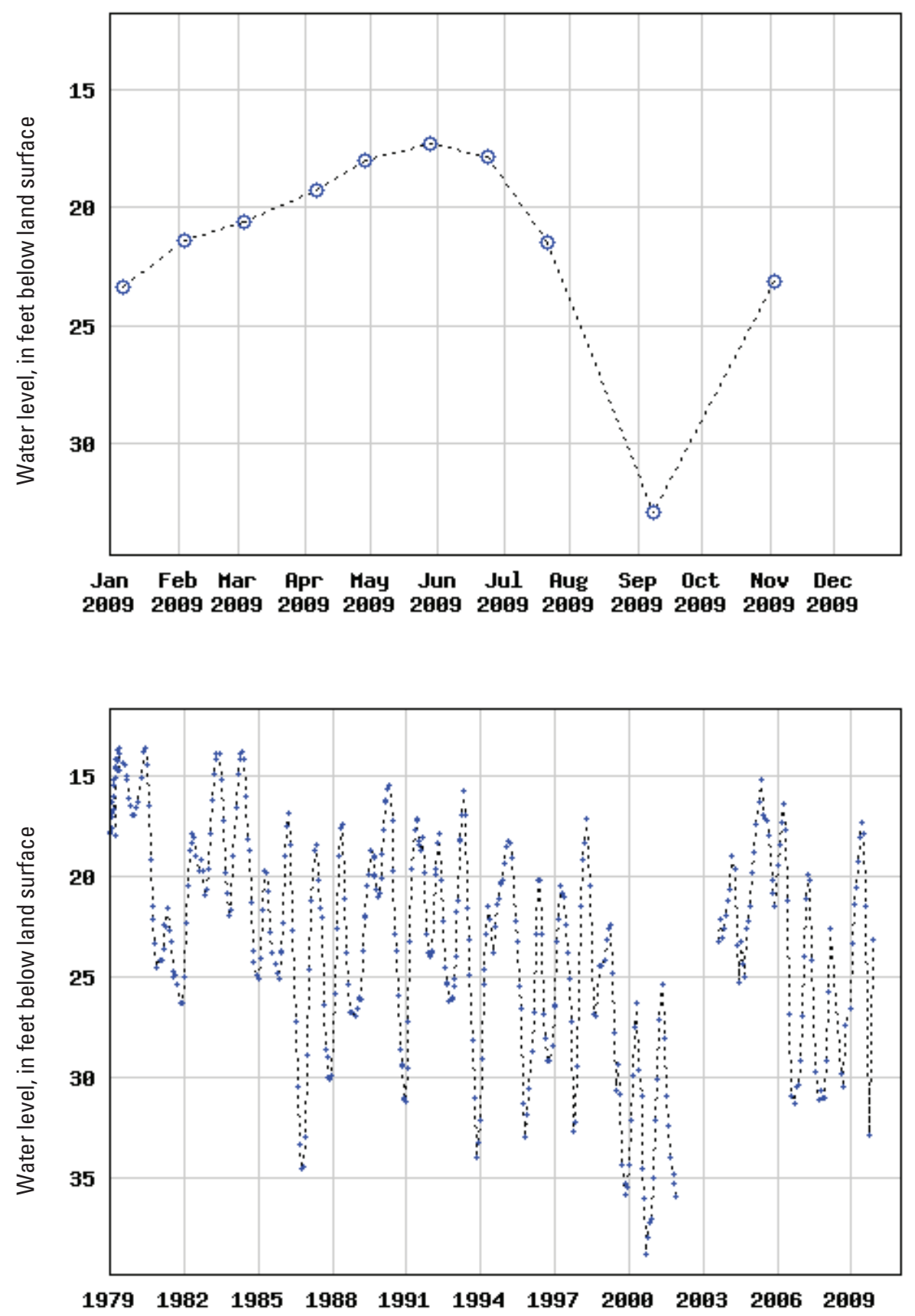

Figure 1-22. Periodic water levels in well 11L001, Claiborne aquifer, 1979-2009. 


\section{Clayton Aquifer}

Site Number: 312654084210103

\section{Site Name: $11 \mathrm{~K} 005$}

Latitude: $31^{\circ} 26^{\prime} 55^{\prime \prime}$ Longitude: $84^{\circ} 21^{\prime} 01^{\prime \prime}$

Well Depth: 646 feet

Dougherty County

Datum: 180 feet

Period of Record: 1979 - 2009

Well Diameter: 6 inches
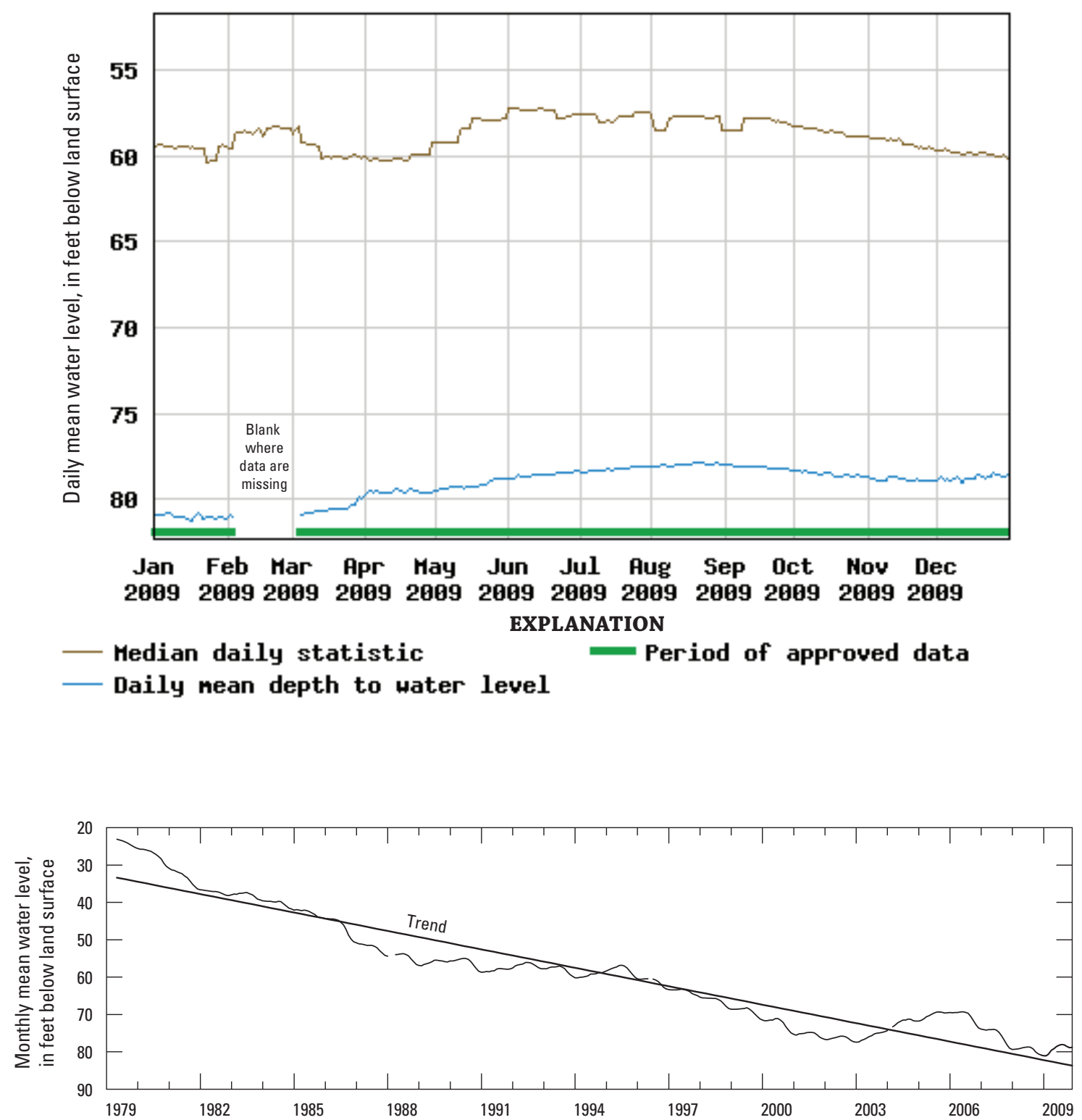

Figure 1-23. Daily and monthly mean water levels in well 11K005, Clayton aquifer, 1979-2009. 


\section{Clayton Aquifer}

Site Number: 313532084203501

Latitude: $31^{\circ} 35^{\prime} 33^{\prime \prime}$ Longitude: $84^{\circ} 20^{\prime} 32^{\prime \prime}$ Well Depth: 656 feet
Dougherty County

Datum: 222 feet

\section{Site Name: 11L002}

Period of Record: 1973 - 2009

Well Diameter: 3 inches

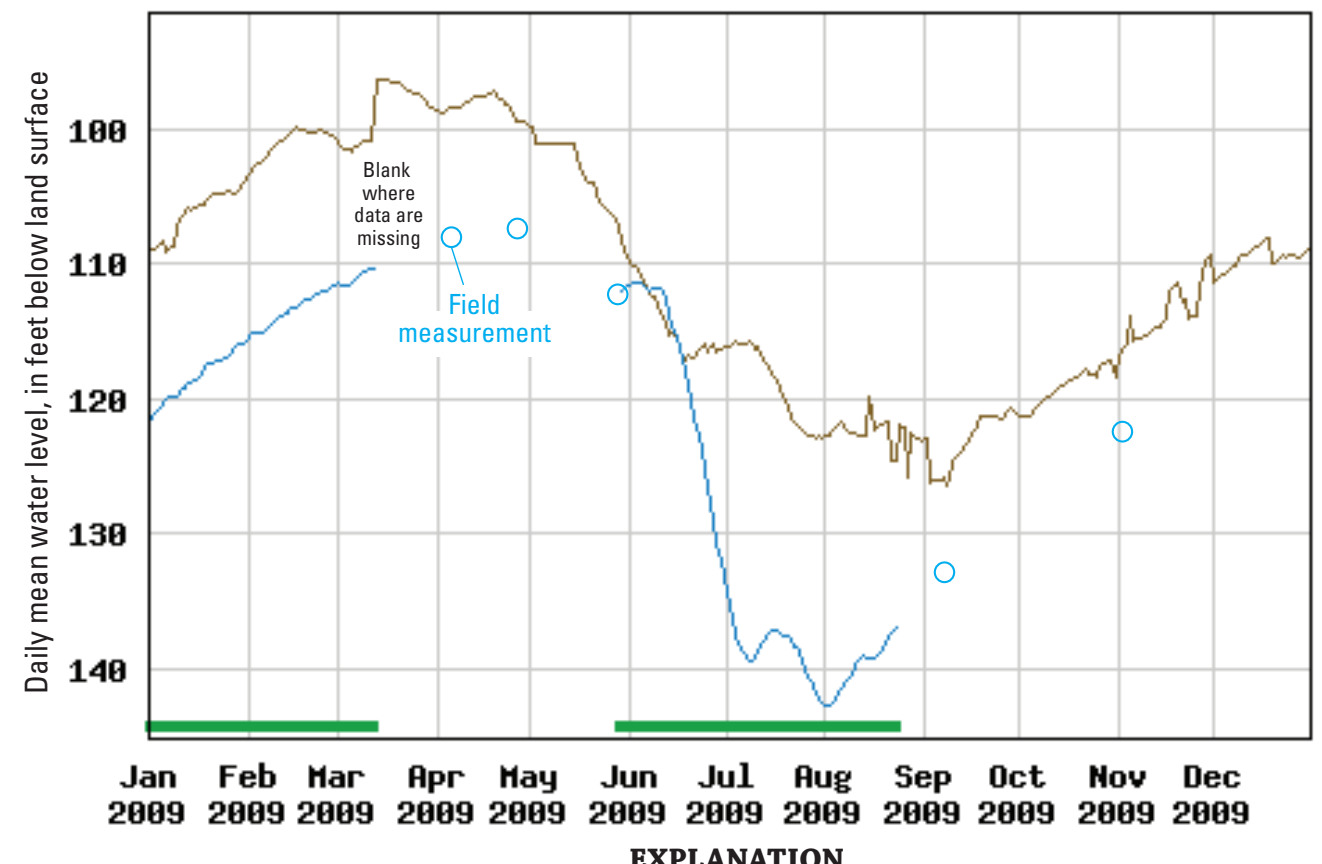

Median daily statistic Period of approved data Daily nean depth to uater level

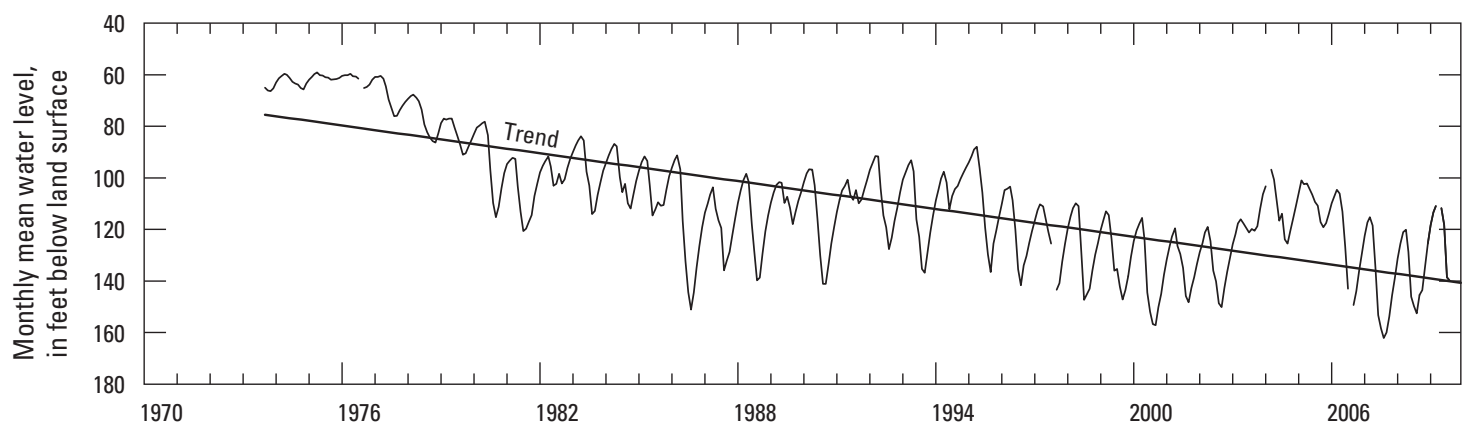

Figure 1-24. Daily and monthly mean water levels in well 11L002, Clayton aquifer, 1973-2009. 


\section{Clayton Aquifer}

Site Number: 313534084103002

Latitude: $31^{\circ} 35^{\prime} 35^{\prime \prime}$ Longitude: $24^{\circ} 10^{\prime} 30^{\prime \prime}$

Well Depth: 690 feet
Lee County

Datum: 195 feet
Site Name: 12L020

Period of Record: 1978 - 2009

Well Diameter: 4 inches
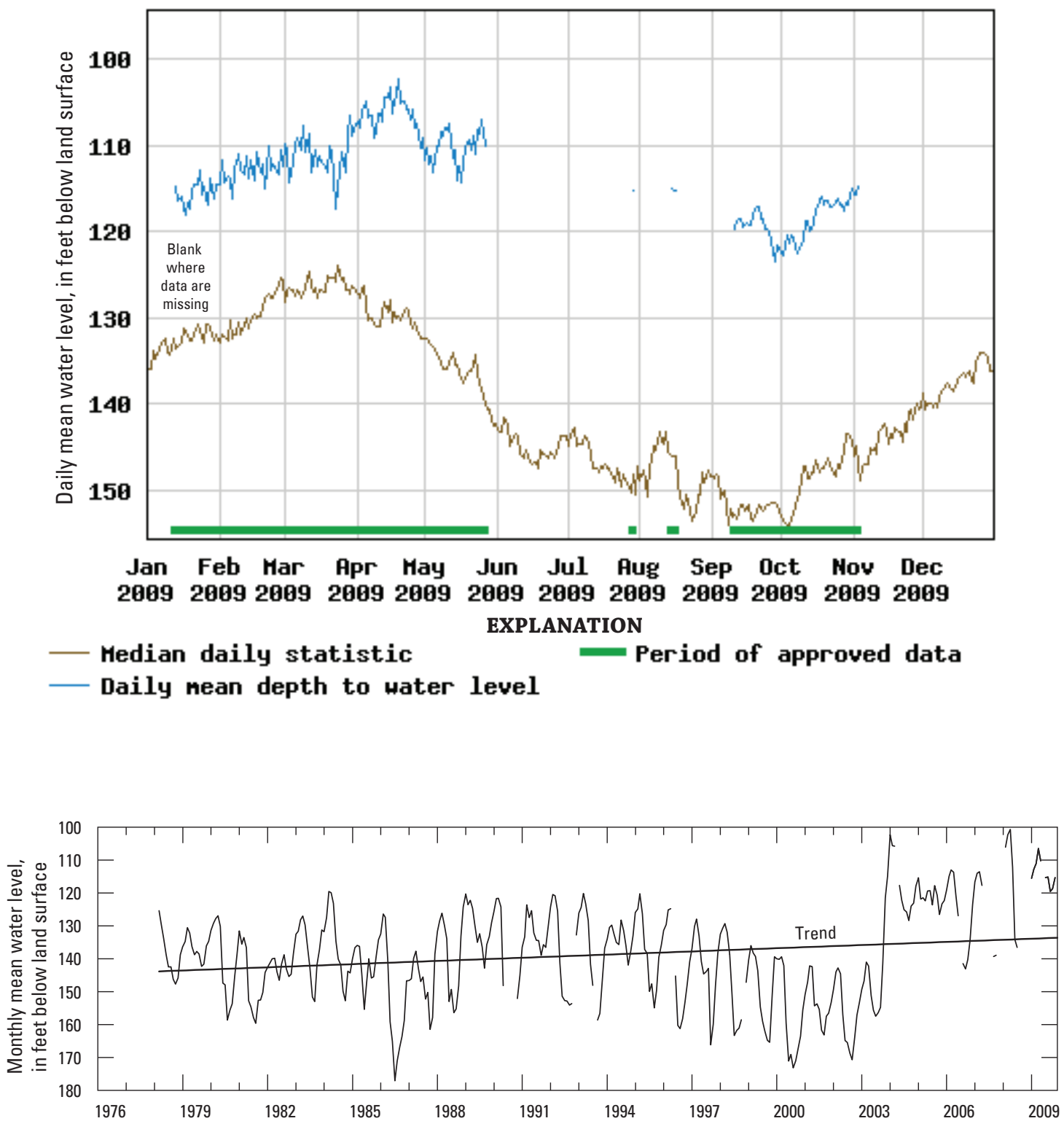

Figure 1-25. Daily and monthly mean water levels in well 12L020, Clayton aquifer, 1978-2009. 


\section{Clayton Aquifer}

Site Number: 313812084125001

Latitude: $31^{\circ} 38^{\prime} 11^{\prime \prime}$ Longitude: $84^{\circ} 12^{\prime} 49^{\prime \prime}$ Well Depth: 650 feet
Site Name: 12M002

Lee County

Datum: 240 feet
Period of Record: 1978 - 2009

Well Diameter: 6 inches

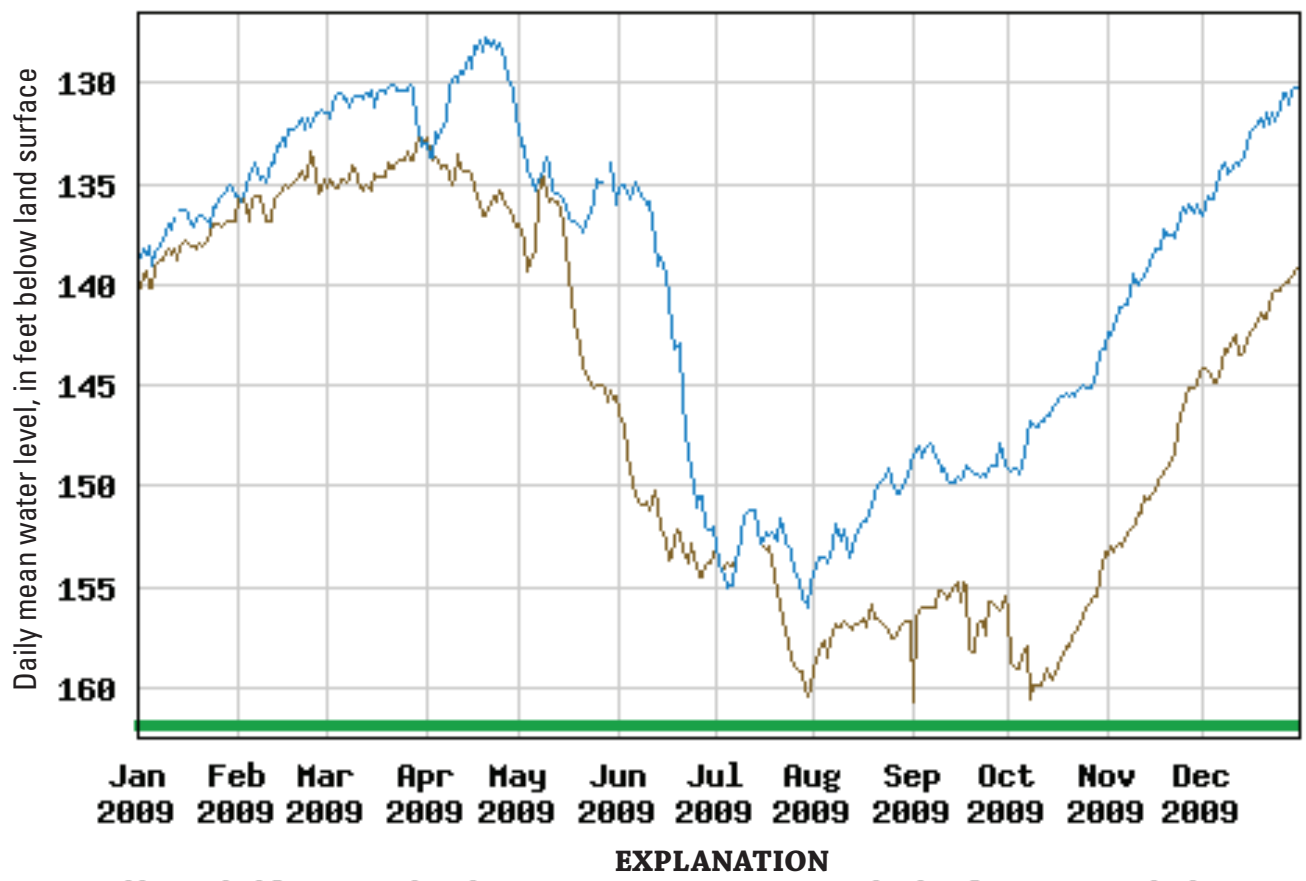

Median daily statistic Period of approved data

Daily nean depth to uater level

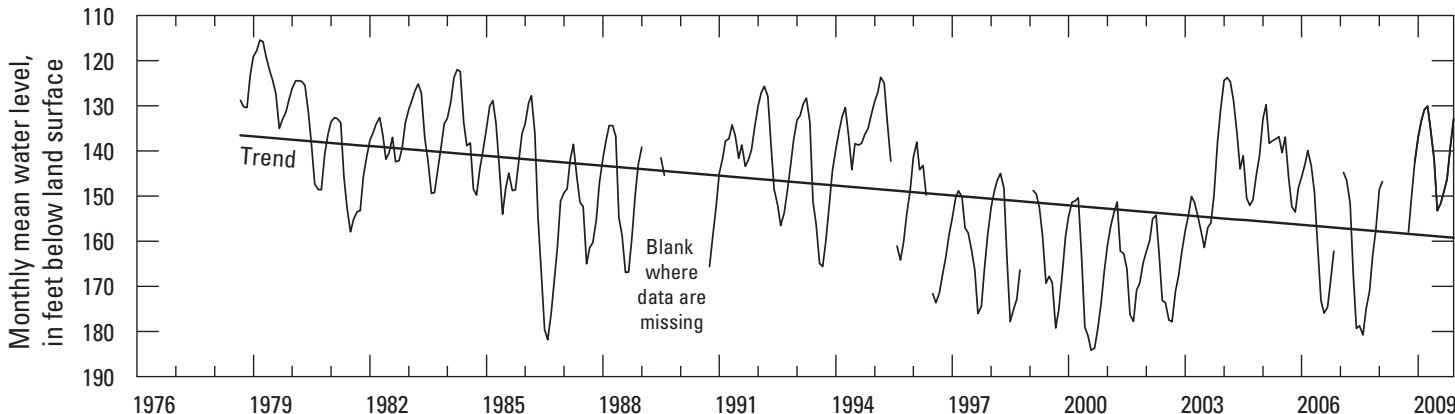

Figure 1-26. Daily and monthly mean water levels in well 12M002, Clayton aquifer, 1978-2009. 


\section{Clayton Aquifer}

Site Number: 313554084062501

Latitude: $31^{\circ} 35^{\prime} 52^{\prime \prime}$ Longitude: $84^{\circ} 06^{\prime} 24^{\prime \prime}$

Well Depth: 760 feet

Dougherty County

Datum: 212 feet

Site Name: 13L002

Period of Record: $1957-2009$

Well Diameter: 12 inches
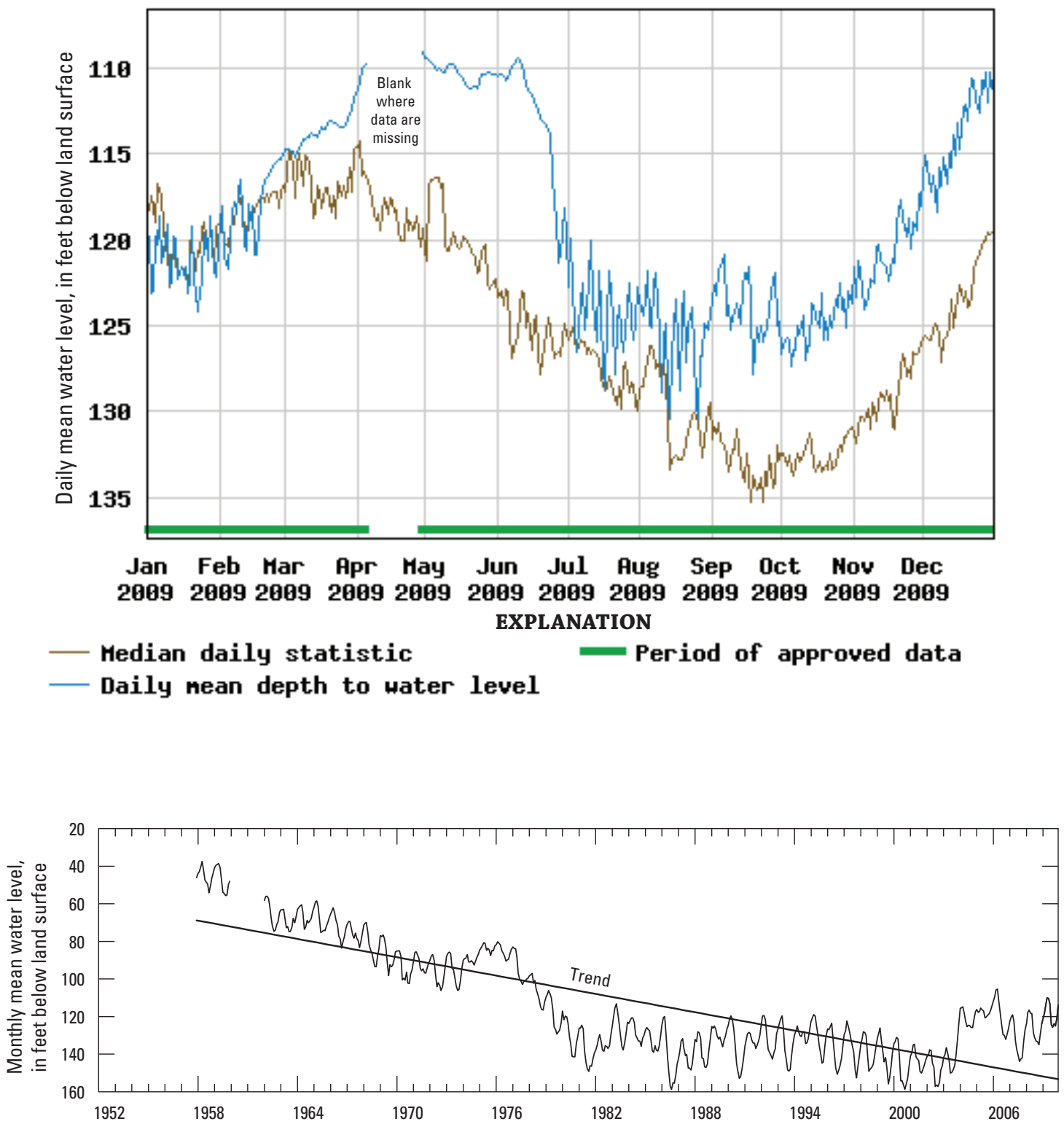

Figure 1-27. Daily and monthly mean water levels in well 13L002, Clayton aquifer, 1957-2009. 


\section{Clayton Aquifer}

Site Number: 313105084064202

Latitude: $31^{\circ} 31^{\prime} 06^{\prime \prime}$ Longitude: $84^{\circ} 06^{\prime} 43^{\prime \prime}$ Well Depth: 882 feet
Site Name: 13L013

Dougherty County

Datum: 195 feet
Period of Record: 1978 - 2009

Well Diameter: 60 inches
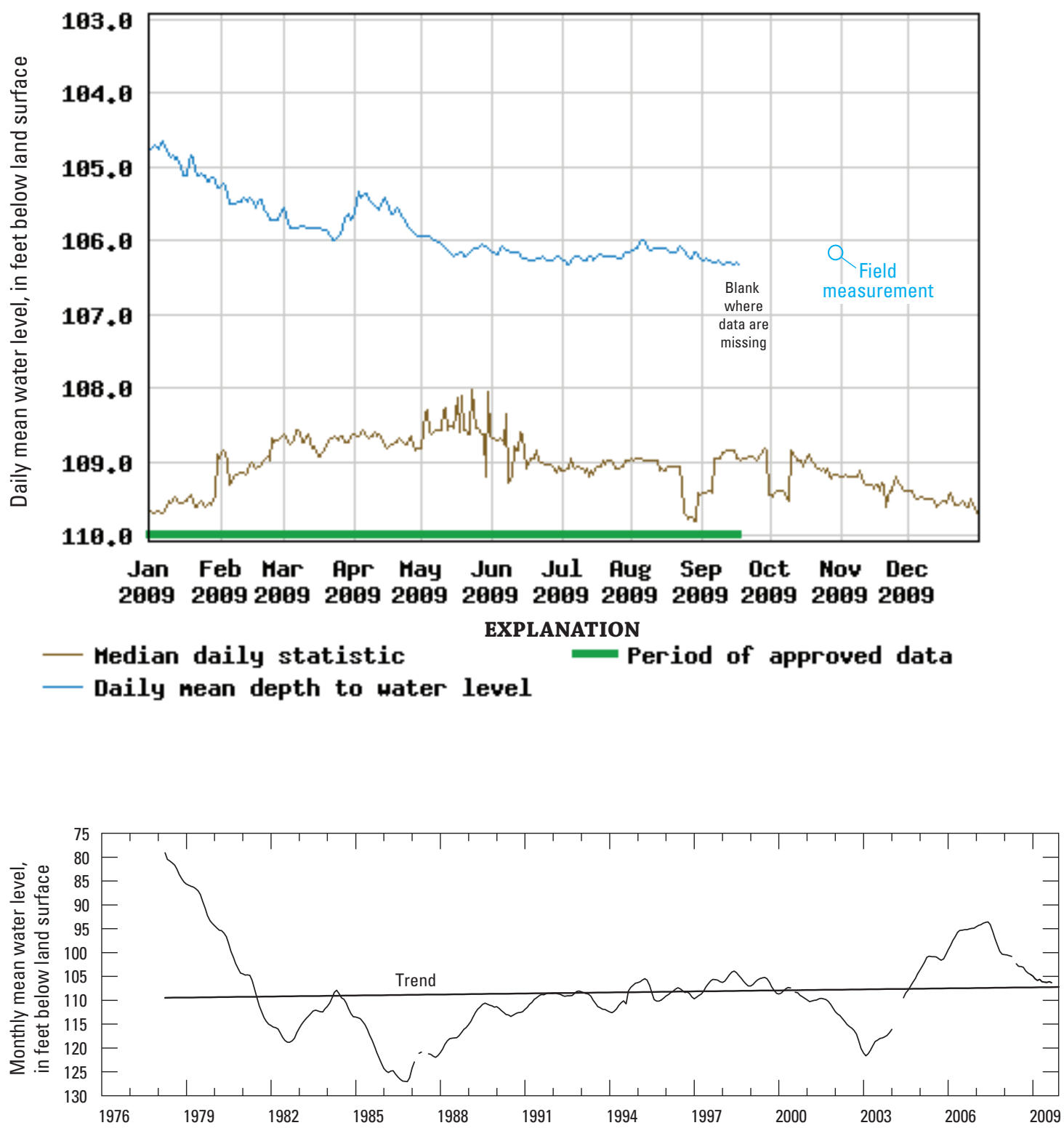

Figure 1-28. Daily and monthly mean water levels in well 13L013, Clayton aquifer, 1978-2009. 
Providence Aquifer

Site Number: 313534084103003

Latitude: $31^{\circ} 35^{\prime} 38^{\prime \prime}$ Longitude: $84^{\circ} 10^{\prime} 29^{\prime \prime}$

Well Depth: 846 feet
Site Name: 12L021

Dougherty County

Datum: 195 feet
Period of Record: 1978 - 2009

Well Diameter: 14 inches
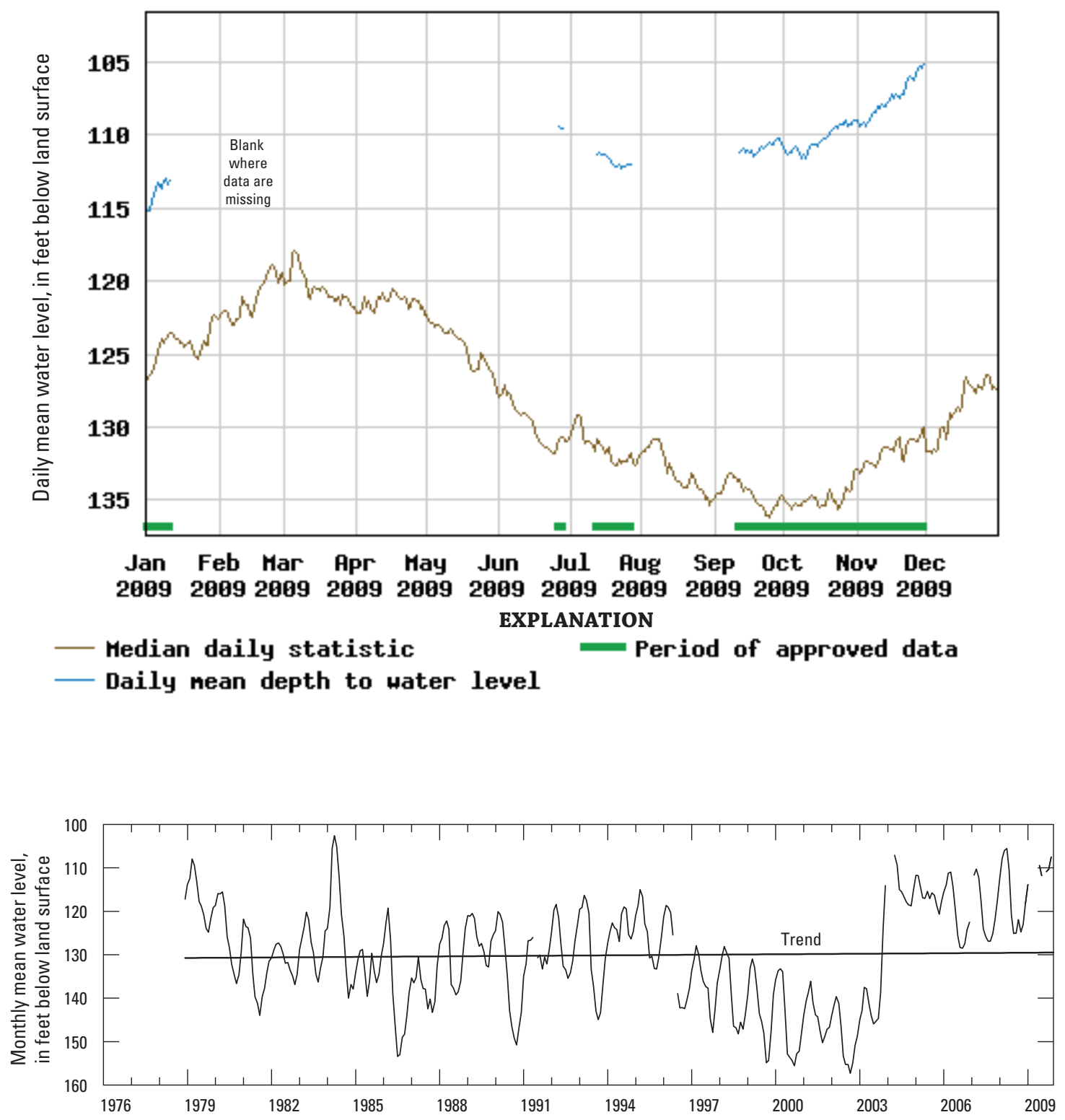

Figure 1-29. Daily and monthly mean water levels in well 12L021, Providence aquifer, 1978-2009. 


\section{Appendix 2. Regression Statistics}

The following is from Peck, M.F., Leeth, D.C., and Painter, J.A., 2011, Groundwater conditions and studies in Georgia, 2008-2009: U.S. Geological Survey Scientific Investigations Report 2011-5048, 83 p.

Water-level trends in this report were estimated by applying the Levenberg-Marquardt Algorithm (LMA; Moré, 1978) to monthly mean water-level data for the period of record and during 2008-2009. Although the LMA typically is used for nonlinear fitting, it also can be used for deriving linear fits very near values derived using ordinary least squares fitting. In concept, LMA works by optimizing a mathematical function (called a merit function by statisticians) that measures how well the function represents the data. In this report, the merit function is the weighted sum of the squares of the differences (informally known as chi-squared and represented in equations and tables as $\chi^{2}$ ).

In this report, the steps involved in minimizing this merit function are as follows:

1. Estimate a value for the slope and intercept, and calculate a line based on this estimate.

2. Calculate how far this line lies from the data (using the $\chi^{2}$ ). Adjust the line so that it lies closer to center of the data.

3. Repeat this until adjustments no longer affect the $\chi^{2}$ value.

Each step is completed through manipulations of algebraic matrices, that are beyond the scope of this report, but are fully explained in Moré, (1978).

Summary statistics for the straight line (linear) fits of water-level trends described in the main body of the report are provided here as an indicator of goodness of fit (Janert, 2010), and so that readers can make decisions based on their tolerance for risk. These include:

- The degrees of freedom representing the number of data points minus the variables used. For this evaluation, two variables are used-slope (m) and intercept (b). A general rule of thumb is that the residuals and the $\chi^{2}$ should be in the same order of magnitude, for the fit to be reasonable (with some exceptions).

- The root mean square error (RMSE) of the residuals is the square root of the average squared distance of a data point from the fitted line. RMSE units are in the same units as the quantity being estimated (in this report, feet).

- The chi-squared is the sum of squared residuals (differences) between the monthly mean water level and the values computed by the algorithm after the final iteration. Thus, the term "least-squares" fitting. The $\chi^{2}$ from the fit along with $\chi^{2}$ distribution tables may be used to estimate confidence intervals.

- The standard error (SE) of a variable ( $\mathrm{m}$ or $\mathrm{b}$ in this report), expressed as a percentage, is a measure of how well $\mathrm{m}$ or $\mathrm{b}$ has been estimated and affects the location of the regression line. The greater the standard error, the greater the scatter around the regression line. In other words, standard error is a measure of dispersion. 
Table 2-1. Regression statistics used for estimating water-level trends in graphs in Appendix 1.

[Modified from Peck and others, 2011; \%, percent]

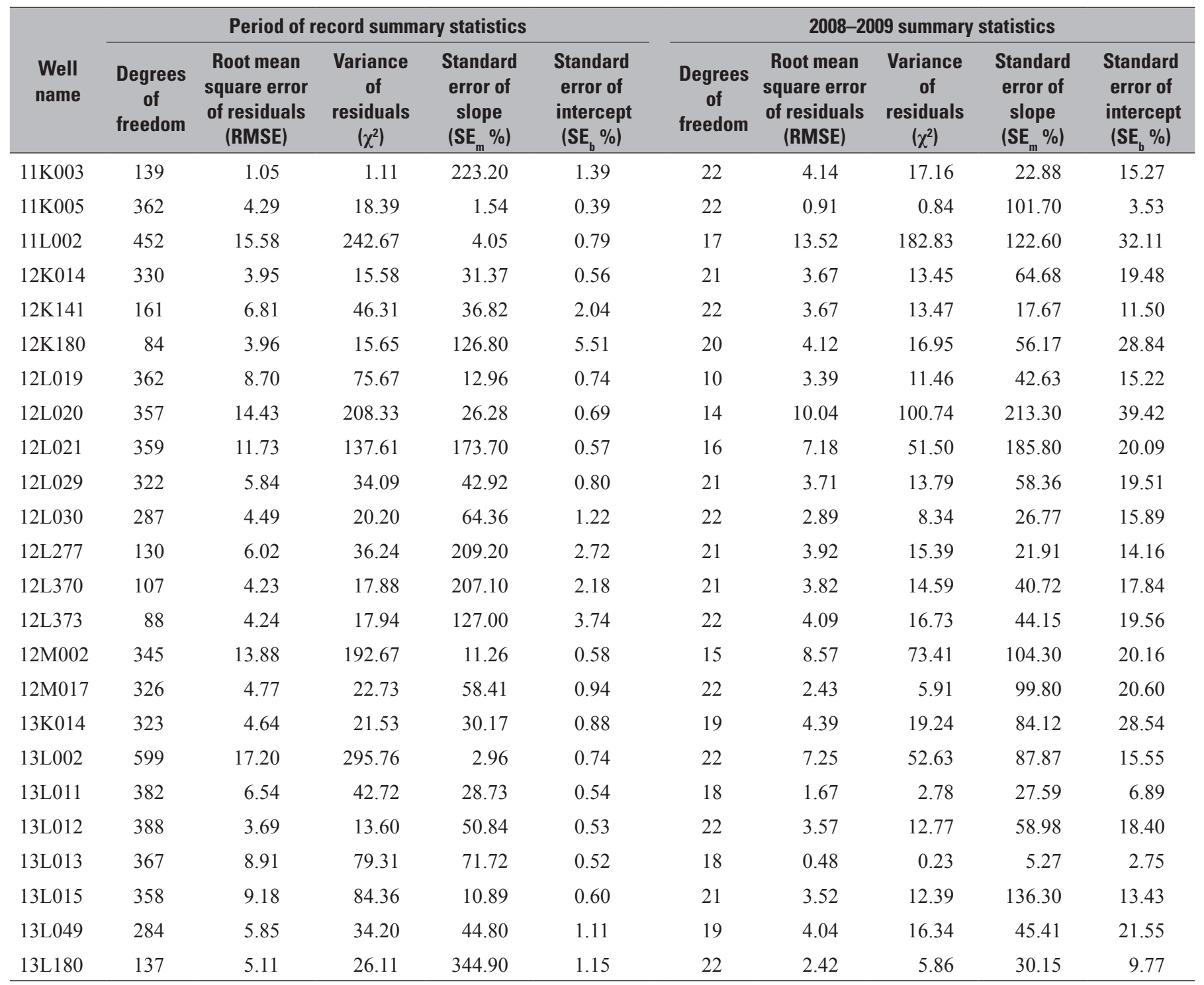


Appendix 3. Water-Quality Data from the Albany Area of Dougherty County, Georgia, November 2009 
Table 3-1. Site information for water-quality data from the Albany area of Dougherty County, Georgia, November 2009.

[-, no data or not applicable; see fig. 11 for site locations]

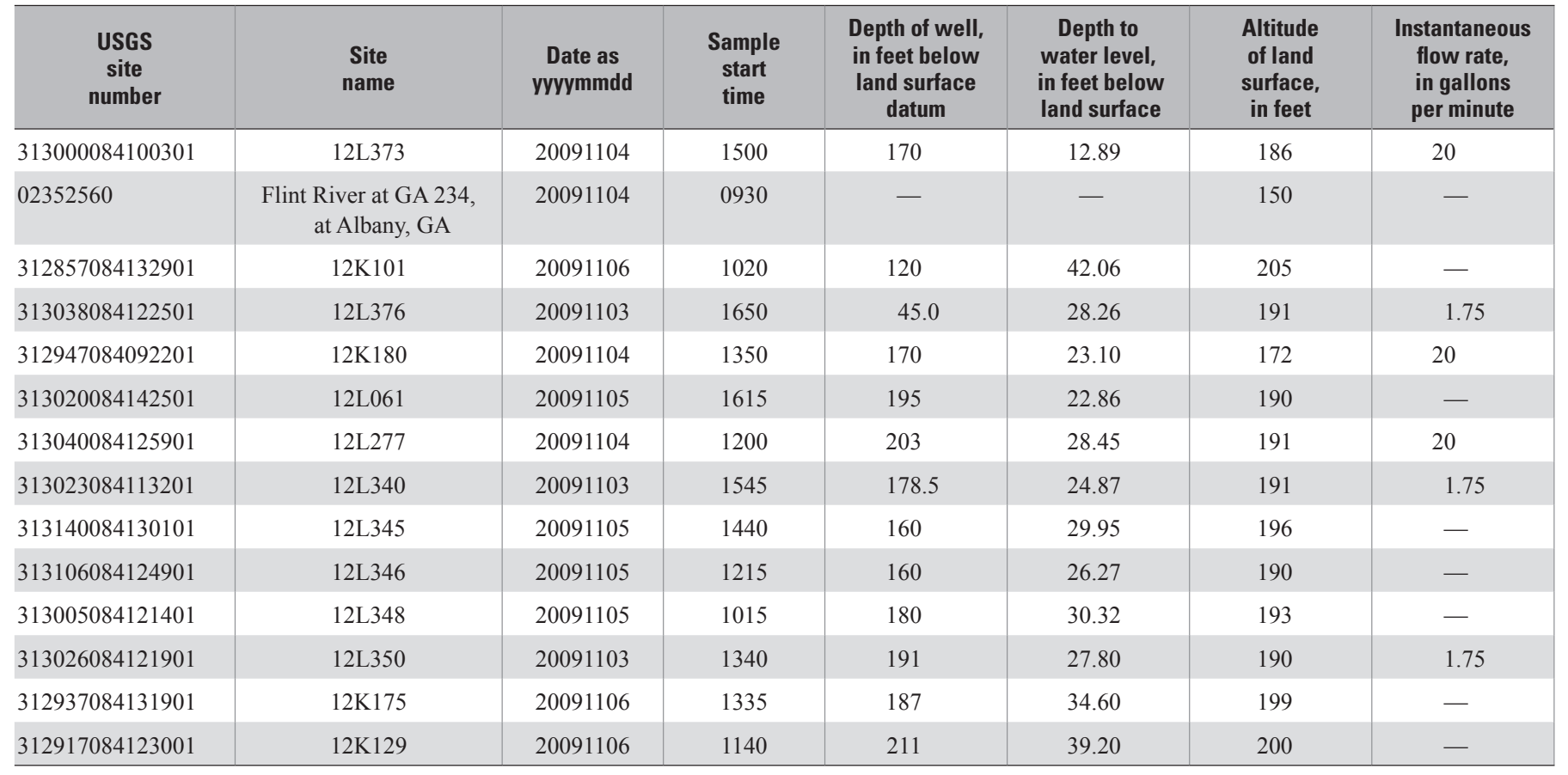

Table 3-2. Field parameters for water-quality samples from the Albany area of Dougherty County, Georgia, November 2009.

$\left[{ }^{\circ} \mathrm{C}\right.$, degrees Celsius; see fig. 11 for site locations $]$

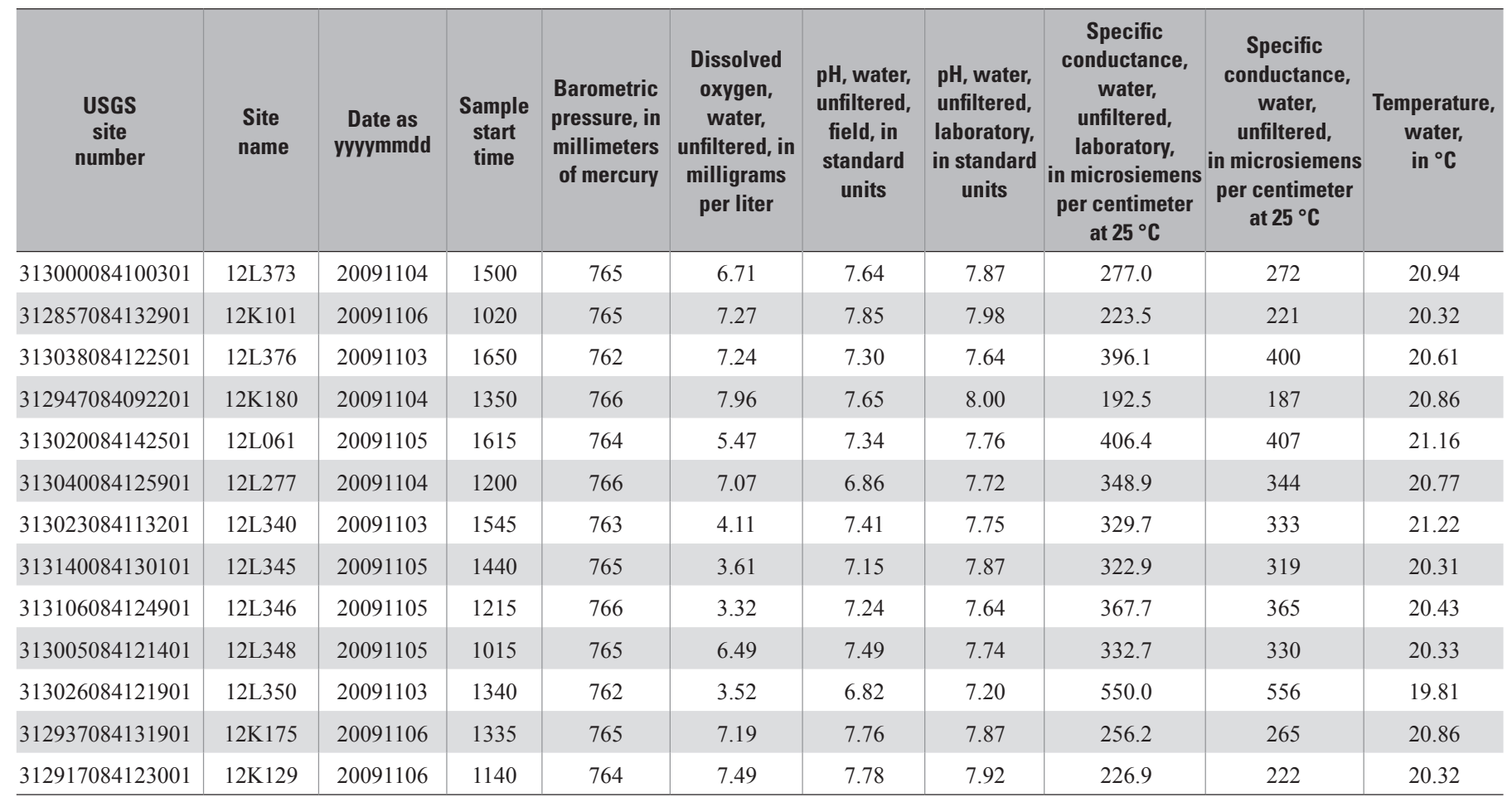


Table 3-3. Major cations and anions from the Albany area of Dougherty County, Georgia, November 2009.

[See fig. 11 for site locations]

\begin{tabular}{|c|c|c|c|c|c|c|c|c|c|c|}
\hline $\begin{array}{l}\text { USGS } \\
\text { site } \\
\text { number }\end{array}$ & $\begin{array}{c}\text { Site } \\
\text { name }\end{array}$ & $\begin{array}{c}\text { Calcium, } \\
\text { water, } \\
\text { filtered }\end{array}$ & $\begin{array}{c}\text { Magnesium, } \\
\text { water, } \\
\text { filtered }\end{array}$ & $\begin{array}{l}\text { Potassium, } \\
\text { water, } \\
\text { filtered }\end{array}$ & $\begin{array}{c}\text { Sodium, } \\
\text { water, } \\
\text { filtered }\end{array}$ & $\begin{array}{c}\text { Acid } \\
\text { neutralizing } \\
\text { capacity, } \\
\text { water, } \\
\text { unfiltered, } \\
\text { fixed } \\
\text { endpoint } \\
\text { (pH 4.5) } \\
\text { titration, } \\
\text { laboratory, } \\
\text { as calcium } \\
\text { carbonate }\end{array}$ & $\begin{array}{c}\text { Chloride, } \\
\text { water, } \\
\text { filtered }\end{array}$ & $\begin{array}{c}\text { Fluoride, } \\
\text { water, } \\
\text { filtered }\end{array}$ & $\begin{array}{l}\text { Silica, } \\
\text { water, } \\
\text { filtered, } \\
\text { as } \mathrm{SiO}_{2}\end{array}$ & $\begin{array}{l}\text { Sulfate, } \\
\text { water, } \\
\text { filtered }\end{array}$ \\
\hline & & \multicolumn{9}{|c|}{ Milligrams per liter } \\
\hline 313000084100301 & 12L373 & 49.06 & 0.867 & 0.358 & 2.147 & 91.30 & 8.308 & 0.08 & 7.896 & 0.592 \\
\hline 02352560 & $\begin{array}{r}\text { Flint River at } \\
\text { GA 234, at } \\
\text { Albany, GA }\end{array}$ & 7.516 & 1.258 & 1.758 & 6.036 & 24.29 & 5.441 & 0.08 & 10.701 & 6.422 \\
\hline 312947084092201 & $12 \mathrm{~K} 180$ & 35.92 & 0.518 & 0.275 & 1.426 & 85.6 & 2.871 & 0.08 & 6.744 & 0.335 \\
\hline 313020084142501 & 12L061 & 73.61 & 1.671 & 1.085 & 4.752 & 140.1 & 11.072 & 0.08 & 9.802 & 1.283 \\
\hline 313040084125901 & 12L277 & 62.34 & 1.043 & 0.829 & 2.563 & 123.4 & 10.047 & 0.08 & 9.009 & 1.410 \\
\hline 313023084113201 & $12 \mathrm{~L} 340$ & 62.28 & 0.849 & 0.494 & 2.661 & 137.7 & 7.603 & 0.08 & 8.894 & 1.319 \\
\hline 313140084130101 & 12L345 & 60.76 & 0.842 & 0.307 & 2.476 & 139.5 & 5.868 & 0.08 & 9.514 & 1.061 \\
\hline 313106084124901 & $12 \mathrm{~L} 346$ & 69.13 & 1.259 & 0.515 & 2.850 & 149.9 & 7.828 & 0.08 & 9.115 & 1.884 \\
\hline 313005084121401 & 12L348 & 60.53 & 1.136 & 0.433 & 3.209 & 126.2 & 8.884 & 0.08 & 9.046 & 0.722 \\
\hline 313026084121901 & $12 \mathrm{~L} 350$ & 111.60 & 1.094 & 0.412 & 3.343 & 285.0 & 5.785 & 0.08 & 11.738 & 1.225 \\
\hline
\end{tabular}


Table 3-4. Nutrients and biological data from the Albany area of Dougherty County, Georgia, November 2009.

[See fig. 11 for site locations]

\begin{tabular}{|c|c|c|c|c|}
\hline $\begin{array}{l}\text { USGS } \\
\text { site }\end{array}$ & $\begin{array}{c}\text { Site } \\
\text { name }\end{array}$ & $\begin{array}{c}\text { Nitrate plus } \\
\text { nitrite, } \\
\text { water, filtered }\end{array}$ & $\begin{array}{c}\text { Nitrite, } \\
\text { water, } \\
\text { filtered }\end{array}$ & $\begin{array}{c}\text { Ammonia, } \\
\text { water, } \\
\text { filtered }\end{array}$ \\
\hline & & \multicolumn{3}{|c|}{ Milligrams per liter as nitrogen } \\
\hline 313000084100301 & $12 \mathrm{~L} 373$ & 8.684 & 0.002 & 0.02 \\
\hline 02352560 & $\begin{array}{c}\text { Flint River at GA 234, } \\
\text { at Albany, GA }\end{array}$ & 0.456 & 0.00388 & 0.02343 \\
\hline 312857084132901 & $12 \mathrm{~K} 101$ & 3.101 & 0.010 & 0.02 \\
\hline 313038084122501 & $12 \mathrm{~L} 376$ & 13.229 & 0.002 & 0.02 \\
\hline 312947084092201 & $12 \mathrm{~K} 180$ & 2.282 & 0.002 & 0.02 \\
\hline 313020084142501 & 12L061 & 12.949 & 0.00374 & 0.02 \\
\hline 313040084125901 & 12L277 & 9.423 & 0.002 & 0.02389 \\
\hline 313023084113201 & $12 \mathrm{~L} 340$ & 5.307 & 0.01158 & 0.02638 \\
\hline 313140084130101 & $12 \mathrm{~L} 345$ & 4.70 & 0.002 & 0.02 \\
\hline 313106084124901 & $12 \mathrm{~L} 346$ & 7.09 & 0.002 & 0.02 \\
\hline 313005084121401 & $12 \mathrm{~L} 348$ & 7.812 & 0.002 & 0.02 \\
\hline 313026084121901 & $12 \mathrm{~L} 350$ & 2.039 & 0.002 & 0.01671 \\
\hline 312937084131901 & $12 \mathrm{~K} 175$ & 5.648 & 0.010 & 0.02 \\
\hline 312917084123001 & $12 \mathrm{~K} 129$ & 3.341 & 0.002 & 0.02 \\
\hline
\end{tabular}


Manuscript approved on January 25, 2012

Edited by Michael Deacon

Illustrations and layout by Caryl J. Wipperfurth

For more information about this publication, contact: USGS Georgia Water Science Center

3039 Amwiler Road

Atlanta, GA 30360

telephone: 770-903-9100

http://ga.water.usgs.gov/ 
